\title{
Cine Substitution of Arenes using the Aryl Carbamate as a Removable Directing Group
}

Tehetena Mesganaw, Noah F. Fine Nathel, and Neil K. Garg*

Department of Chemistry and Biochemistry, University of California, Los Angeles, California 90095

\section{Supporting Information - Table of Contents}

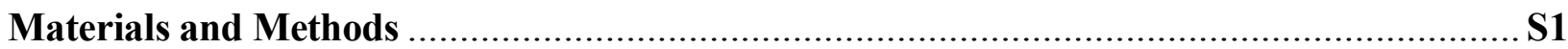

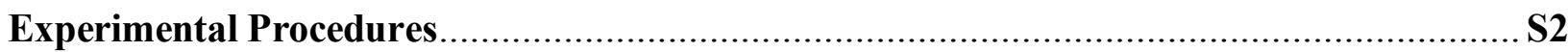

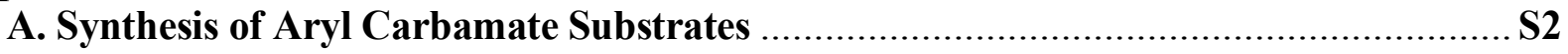

B. Reduction of Aryl Carbamates.......................................................................... S11

C. Cross Coupling Approaches to Ipso and Cine Substituted Products ...................... S18

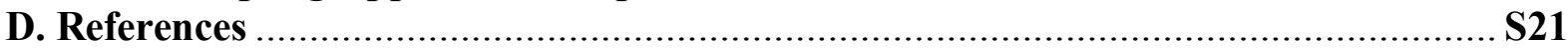

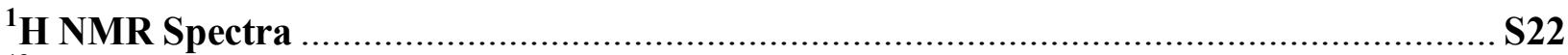

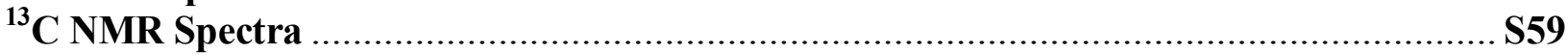

Materials and Methods. Unless stated otherwise, reactions were conducted in flame-dried glassware under an atmosphere of nitrogen using anhydrous solvents (either freshly distilled or passed through activated alumina columns). Unless otherwise stated, commercially obtained reagents were used as received. $\mathrm{NiCl}_{2}\left(\mathrm{PCy}_{3}\right)_{2}$ was obtained from Strem Chemicals, 1,1,3,3-tetramethyldisiloxane (TMDSO) was obtained from Sigma Aldrich and potassium phosphate was obtained from VWR (manufactured by Acros Organics). Reaction temperatures were controlled using an IKAmag temperature modulator, and unless stated otherwise, reactions were performed at room temperature ( $\mathrm{rt}$, approximately $23{ }^{\circ} \mathrm{C}$ ). Thin-layer chromatography (TLC) was conducted with EMD gel 60 F254 pre-coated plates $(0.25 \mathrm{~mm})$ and visualized using a combination of UV, anisaldehyde, ceric ammonium molybdate, iodine, vanillin, and potassium permanganate staining. Silicycle Siliaflash P60 (particle size 0.040-0.063 mm) was used for flash column chromatography. ${ }^{1} \mathrm{H}$ NMR spectra were recorded on Bruker spectrometers (at $300,400,500,600 \mathrm{MHz}$ ) and are reported relative to deuterated solvent signals. Data for ${ }^{1} \mathrm{H}$ NMR spectra are reported as follows: chemical shift $(\delta \mathrm{ppm})$, multiplicity, coupling constant $(\mathrm{Hz})$ and integration. ${ }^{13} \mathrm{C}$ NMR spectra were recorded on Bruker Spectrometers (at $125 \mathrm{MHz}$ ). Data for ${ }^{13} \mathrm{C}$ NMR spectra are reported in terms of chemical shift. ${ }^{19}$ F NMR (at 300, $400 \mathrm{MHz}$ ) spectra are reported in terms of chemical shift. IR spectra were recorded on a Perkin-Elmer 100 spectrometer and are reported in terms of frequency of absorption $\left(\mathrm{cm}^{-1}\right)$. Melting points are uncorrected and were obtained on a Laboratory Devices Mel-Temp II instrument. High resolution mass spectra were obtained from both the UC Los Angeles and Irvine Mass Spectrometry Facility. 


\section{Experimental Procedures.}

\section{A. Synthesis of Aryl Carbamate Substrates}

Note: Supporting information for the synthesis of the aryl carbamates shown in Figures 2-5 have previously been reported, ${ }^{1}$ with the exception of the carbamates SI-2, SI-4, SI-6, SI-8, SI-10, SI-13, 4a, $4 \mathbf{b}, 4 \mathbf{c}, 7,8$, and 9 .

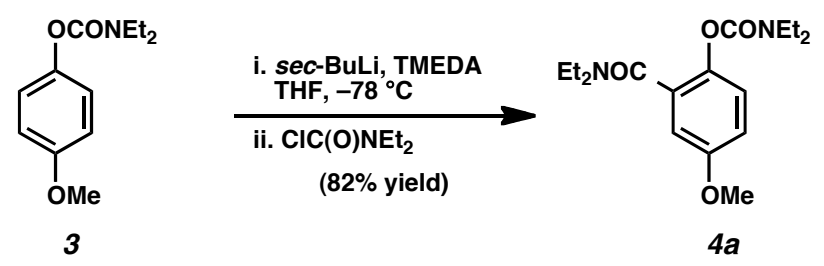

4a. To a solution of carbamate $\mathbf{3}^{1}(0.1 \mathrm{~g}, 0.448 \mathrm{mmol}, 1.0$ equiv) and TMEDA (0.087 $\mathrm{mL}, 0.582 \mathrm{mmol}$, 1.3 equiv) in THF $(2.2 \mathrm{~mL})$ at $-78^{\circ} \mathrm{C}$ was added sec-BuLi $(0.525 \mathrm{~mL}, 0.582 \mathrm{mmol}, 1.3$ equiv) over 15 min. After stirring for $1 \mathrm{~h}, \mathrm{ClC}(\mathrm{O}) \mathrm{NEt}_{2}(0.074 \mathrm{~mL}, 0.582 \mathrm{mmol}, 1.3$ equiv) was added over $10 \mathrm{~min}$. The reaction was stirred at $-78{ }^{\circ} \mathrm{C}$ for $1 \mathrm{~h}$, allowed to warm to $23{ }^{\circ} \mathrm{C}$, and then quenched with saturated aqueous $\mathrm{NH}_{4} \mathrm{Cl}(5 \mathrm{~mL})$. The reaction mixture was diluted with $\mathrm{H}_{2} \mathrm{O}(5 \mathrm{~mL})$ and EtOAc $(10 \mathrm{~mL})$. The layers were separated, and the aqueous layer was extracted with EtOAc $(3$ x $10 \mathrm{~mL})$. The combined organic layers were washed with brine $(10 \mathrm{~mL})$, dried over $\mathrm{MgSO}_{4}$ and concentrated under reduced pressure. The crude residue was purified by flash chromatography (3:1 Hexanes:EtOAc) to yield amide product 4a (0.118 g, 82\% yield) as a light yellow oil. $\mathrm{R}_{f} 0.12$ (3:1 Hexanes:EtOAc); ${ }^{1} \mathrm{H}$ NMR (500 $\left.\mathrm{MHz}, \mathrm{CDCl}_{3}\right): \delta 7.12(\mathrm{~d}, J=9.0,1 \mathrm{H}), 6.90(\mathrm{dd}, J=9.0,3.0,1 \mathrm{H}), 6.78(\mathrm{~d}, J=3.0,1 \mathrm{H}), 3.80(\mathrm{~s}, 3 \mathrm{H})$, 3.74 (as, $1 \mathrm{H}), 3.44-3.23(\mathrm{~m}, 6 \mathrm{H}), 3.13$ (as, $1 \mathrm{H}), 1.21$ (atd, $J=7.0,1.5,6 \mathrm{H}), 1.17(\mathrm{t}, J=7.0,3 \mathrm{H}), 1.07$ $(\mathrm{t}, J=7.0,3 \mathrm{H}) ;{ }^{13} \mathrm{C} \mathrm{NMR}\left(125 \mathrm{MHz}, \mathrm{CDCl}_{3}\right): \delta 167.4,156.6,153.9,140.8,131.3,124.3,115.0,111.5$, 55.7, 42.8, 42.2, 42.0, 38.6, 14.2, 13.9, 13.4, 12.7; IR (film): 2973, 2936, 1714, 1634, 1197, $1152 \mathrm{~cm}^{-1}$; HRMS-ESI $(m / z)[\mathrm{M}+\mathrm{H}]^{+}$calcd for $\mathrm{C}_{17} \mathrm{H}_{26} \mathrm{~N}_{2} \mathrm{O}_{4} \mathrm{H}, 323.1971$; found, 323.1971. 


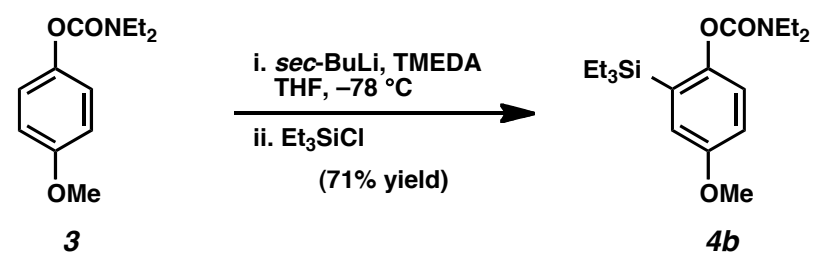

4b. To a solution of carbamate $\mathbf{3}^{1}(0.1 \mathrm{~g}, 0.448 \mathrm{mmol}, 1.0$ equiv) and TMEDA (0.087 mL, $0.582 \mathrm{mmol}$, 1.3 equiv) in THF $(2.2 \mathrm{~mL})$ at $-78^{\circ} \mathrm{C}$ was added sec-BuLi $(0.525 \mathrm{~mL}, 0.582 \mathrm{mmol}, 1.3$ equiv) over 15 min. After stirring for $1 \mathrm{~h}, \mathrm{Et}_{3} \mathrm{SiCl}(0.098 \mathrm{~mL}, 0.582 \mathrm{mmol}, 1.3 \mathrm{equiv})$ was added over $10 \mathrm{~min}$. The reaction was stirred at $-78{ }^{\circ} \mathrm{C}$ for $1 \mathrm{~h}$, allowed to warm to $23{ }^{\circ} \mathrm{C}$, and then quenched with saturated aqueous $\mathrm{NH}_{4} \mathrm{Cl}(5 \mathrm{~mL})$. The reaction mixture was diluted with $\mathrm{H}_{2} \mathrm{O}(5 \mathrm{~mL})$ and EtOAc $(10 \mathrm{~mL})$. The layers were separated, and the aqueous layer was extracted with EtOAc $(3 \mathrm{x} 10 \mathrm{~mL})$. The combined organic layers were washed with brine $(10 \mathrm{~mL})$, dried over $\mathrm{MgSO}_{4}$ and concentrated under reduced pressure. The crude residue was purified by flash chromatography (20:1 Hexanes:EtOAc) to yield silyl product 4b (0.107 g, 71\% yield) as a clear oil. $\mathrm{R}_{f} 0.52$ (3:1 Hexanes:EtOAc); ${ }^{1} \mathrm{H}$ NMR (400 MHz, $\left.\mathrm{CDCl}_{3}\right): \delta 6.97-6.87(\mathrm{~m}, 3 \mathrm{H}), 3.81(\mathrm{~s}, 3 \mathrm{H}), 3.47(\mathrm{q}, J=6.8,2 \mathrm{H}), 3.40(\mathrm{q}, J=7.2,2 \mathrm{H}), 1.25(\mathrm{t}, J=7.2$, $3 \mathrm{H}), 1.19(\mathrm{t}, J=6.8,6 \mathrm{H}), 0.96$ (at, $J=8.0,9 \mathrm{H}), 0.81$ (aq, $J=8.0,6 \mathrm{H}) ;{ }^{13} \mathrm{C} \mathrm{NMR}\left(100 \mathrm{MHz}, \mathrm{CDCl}_{3}\right): \delta$ 156.5, 155.3, 150.0, 123.3, 119.8, 118.4, 83.7, 55.8, 42.1, 41.7, 25.0, 14.2, 13.6; IR (film): 2954, 2876, 1715, 1264, 1186, $1153 \mathrm{~cm}^{-1}$; HRMS-ESI $(\mathrm{m} / z)[\mathrm{M}+\mathrm{H}]^{+}$calcd for $\mathrm{C}_{18} \mathrm{H}_{31} \mathrm{NO}_{3} \mathrm{SiH}, 338.2151$; found, 338.2153 .

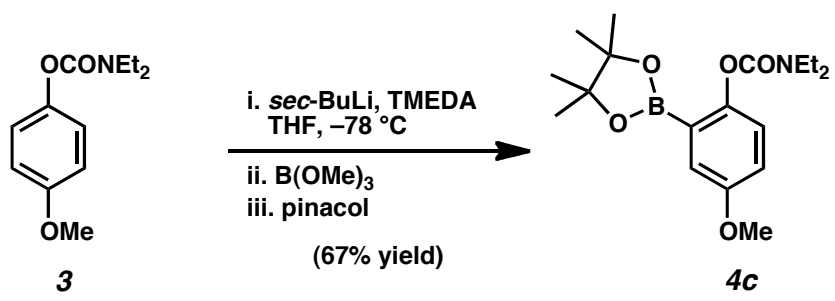

4c. To a solution of carbamate $\mathbf{3}^{1}(0.1 \mathrm{~g}, 0.448 \mathrm{mmol}, 1.0$ equiv) and TMEDA $(0.087 \mathrm{~mL}, 0.582 \mathrm{mmol}$, 1.3 equiv) in THF $(2.2 \mathrm{~mL})$ at $-78^{\circ} \mathrm{C}$ was added sec-BuLi $(0.525 \mathrm{~mL}, 0.582 \mathrm{mmol}, 1.3$ equiv) over 15 min. After stirring for $1 \mathrm{~h}$, trimethylborate $(0.065 \mathrm{~mL}, 0.582 \mathrm{mmol}, 1.3$ equiv) was added over $10 \mathrm{~min}$. The reaction was stirred at $-78^{\circ} \mathrm{C}$ for $1 \mathrm{~h}$, allowed to warm to $23{ }^{\circ} \mathrm{C}$, and then quenched with saturated aqueous $\mathrm{NH}_{4} \mathrm{Cl}(5 \mathrm{~mL})$. The reaction mixture was diluted with $\mathrm{H}_{2} \mathrm{O}(5 \mathrm{~mL})$ and EtOAc $(10 \mathrm{~mL})$. The layers were separated, and the aqueous layer was extracted with EtOAc $(3 \times 10 \mathrm{~mL})$. The combined organic layers were washed with brine $(10 \mathrm{~mL})$, dried over $\mathrm{MgSO}_{4}$ and concentrated under reduced 
pressure. The crude residue was dissolved in $\mathrm{MeOH}(30 \mathrm{ml})$ with pinacol $(0.069 \mathrm{~g}, 0.582 \mathrm{mmol})$, concentrated in vacuo, and purified by flash chromatography (5:1 Hexanes:EtOAc) to yield pinacolborane product $4 \mathrm{c}\left(0.105 \mathrm{~g}, 67 \%\right.$ yield) as a clear oil. $\mathrm{R}_{f} 0.44$ (3:1 Hexanes:EtOAc); ${ }^{1} \mathrm{H}$ NMR $\left(500 \mathrm{MHz}, \mathrm{CDCl}_{3}\right): \delta 7.27(\mathrm{ad}, J=3.0,1 \mathrm{H}), 6.99-6.95(\mathrm{~m}, 2 \mathrm{H}), 3.50$ (q, $\left.J=7.0,2 \mathrm{H}\right), 3.38(\mathrm{q}, J=7.0$, $2 \mathrm{H}), 1.31(\mathrm{~s}, 12 \mathrm{H}), 1.29(\mathrm{t}, J=7.5,3 \mathrm{H}), 1.20(\mathrm{t}, J=7.0,9 \mathrm{H}) ;{ }^{13} \mathrm{C} \mathrm{NMR}\left(125 \mathrm{MHz}, \mathrm{CDCl}_{3}\right): \delta 156.3$, 154.9, 150.2, 130.1, 123.2, 121.1, 114.9, 55.7, 41.9, 41.5, 14.3, 13.4, 7.6, 3.5; IR (film): 2977, 2935, 1712, 1410, 1194, $1156 \mathrm{~cm}^{-1}$; HRMS-ESI $(\mathrm{m} / z)[\mathrm{M}+\mathrm{H}]^{+}$calcd for $\mathrm{C}_{18} \mathrm{H}_{28} \mathrm{BNO}_{5} \mathrm{H}, 350.2142$; found, 350.2144 .
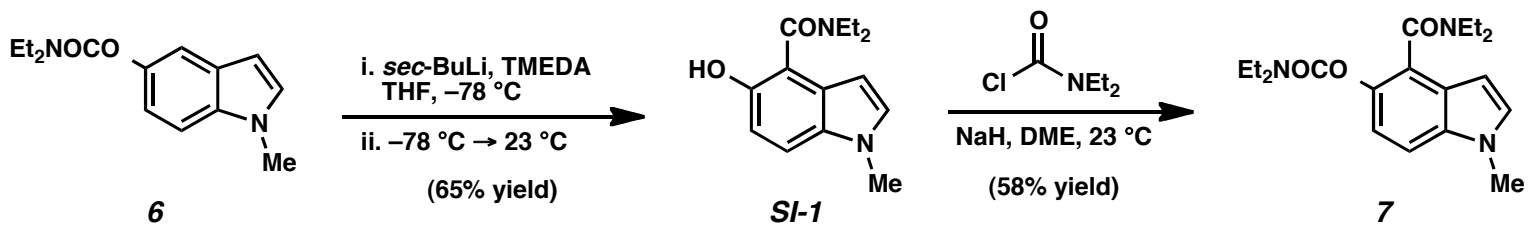

Amide Carbamate 7. To a solution of indole carbamate $6^{2}$ (1.5 g, 6.09 mmol, 1.0 equiv) and TMEDA (1.0 mL, $6.70 \mathrm{mmol}, 1.1$ equiv) in THF $(30 \mathrm{~mL})$ at $-78^{\circ} \mathrm{C}$ was added sec-BuLi $(6.0 \mathrm{~mL}, 6.70 \mathrm{mmol}$, 1.1 equiv) over $15 \mathrm{~min}$. After stirring for $45 \mathrm{~min}$ the reaction was allowed to warm to $23{ }^{\circ} \mathrm{C}$ and stirred for $3 \mathrm{~h}$. The reaction was quenched with $\mathrm{H}_{2} \mathrm{O}(30 \mathrm{~mL})$ and EtOAc $(100 \mathrm{~mL})$. The layers were separated and the aqueous layer was extracted with EtOAc $(4 \times 100 \mathrm{~mL})$. The combined organic layers were washed with brine $(50 \mathrm{~mL})$, dried over $\mathrm{MgSO}_{4}$ and concentrated under reduced pressure. The crude residue was purified by flash chromatography $(7: 1 \rightarrow 5: 1 \rightarrow 4: 1 \rightarrow 2: 1 \rightarrow 1: 1 \rightarrow 1: 2$ Hexanes:Acetone) to yield the amide hydroxyindole product SI-1 (0.980 g, 65\% yield) as a colorless amorphous solid. $\mathrm{R}_{f} 0.13$ (5:1 Hexanes:Acetone); ${ }^{1} \mathrm{H}$ NMR $\left(500 \mathrm{MHz}, \mathrm{CDCl}_{3}\right): \delta 7.33(\mathrm{~d}, J=8.5,1 \mathrm{H})$, 7.23 (at, $J=7.5,1 \mathrm{H}), 7.07-7.09(\mathrm{~m}, 2 \mathrm{H}), 6.44(\mathrm{dd}, J=0.5,3.0,1 \mathrm{H}), 3.81(\mathrm{~s}, 3 \mathrm{H}), 3.65$ (as, 2H), 3.22 (as, 2H), 1.31 (as, 3H), 1.02 (as, 3H); ${ }^{13} \mathrm{C}$ NMR (125 MHz, $\mathrm{CDCl}_{3}$ ): $\delta 170.9,136.9,129.7,129.7$, 125.6, 121.4, 117.2, 109.9, 99.9, 43.2, 38.9, 33.1, 14.6, 13.3; IR (film): 3160, 1596, 1577, 1309, 1255 $\mathrm{cm}^{-1}$; HRMS-ESI $(\mathrm{m} / z)[\mathrm{M}+\mathrm{H}]^{+}$calcd for $\mathrm{C}_{14} \mathrm{H}_{18} \mathrm{~N}_{2} \mathrm{O}_{2} \mathrm{H}, 247.1447$; found, 247.1448.

A round bottom flask was charged with $\mathrm{NaH}(0.175 \mathrm{~g}, 4.38 \mathrm{mmol}, 1.2$ equiv, 60\% dispersion in oil). A solution of amide hydroxyindole SI-1 (0.90 g, $3.65 \mathrm{mmol}, 1$ equiv) in DME (15 mL) and DMSO $(5 \mathrm{~mL})$ was warmed to $50{ }^{\circ} \mathrm{C}$ to fully dissolve the amide hydroxyindole. The homogeneous solution was added dropwise via cannula to the sodium hydride. Diethylcarbamoyl chloride $(0.44 \mathrm{~mL}$, $3.47 \mathrm{mmol}, 0.95$ equiv) was then added dropwise to the reaction vessel. The reaction was stirred for 41 
h. The reaction was diluted with $\mathrm{H}_{2} \mathrm{O}(25 \mathrm{~mL})$ and EtOAc $(25 \mathrm{~mL})$ and the layers were separated. The aqueous layer was extracted with EtOAc $(3 \times 500 \mathrm{~mL})$. The combined organic layers were then washed with $\mathrm{H}_{2} \mathrm{O}(2 \times 50 \mathrm{~mL})$ and brine $(50 \mathrm{~mL})$, dried over $\mathrm{MgSO}_{4}$, and evaporated to dryness. The crude residue was purified by flash chromatography $(6: 1 \rightarrow 4: 1$ Hexanes:Acetone) to yield amide carbamate 7 (0.700 g, 58\% yield) as a yellow oil. $\mathrm{R}_{f} 0.31$ (4:1 Hexanes:Acetone); ${ }^{1} \mathrm{H}$ NMR (500 MHz, $\left.\mathrm{CDCl}_{3}\right): \delta 7.25(\mathrm{~d}, J=5.0,1 \mathrm{H}), 7.06-7.05(\mathrm{~m}, 2 \mathrm{H}), 6.36(\mathrm{~d}, J=3.0,1 \mathrm{H}), 3.79(\mathrm{~s}, 3 \mathrm{H}), 3.72$ (sextet, $J$ $=7.0,1 \mathrm{H}), 3.53$ (sextet, $J=7.0,1 \mathrm{H}), 3.50-3.31(\mathrm{~m}, 4 \mathrm{H}), 3.28$ (sextet, $J=7.0,1 \mathrm{H}), 3.11$ (sextet, $J=$ $7.0,1 \mathrm{H}), 1.27(\mathrm{t}, J=7.0,3 \mathrm{H}), 1.23(\mathrm{t}, J=7.0,3 \mathrm{H}), 1.17(\mathrm{t}, J=7.0,3 \mathrm{H}), 0.98(\mathrm{t}, J=7.0,3 \mathrm{H}) ;{ }^{13} \mathrm{C} \mathrm{NMR}$ (125 MHz, $\left.\mathrm{CDCl}_{3}\right): \delta 167.2,154.7,140.6,134.4,130.2,125.8,121.8,117.4,109.9,100.0,43.0,42.2$, 42.1, 38.5, 33.3, 14.3, 14.2, 13.6, 13.1; IR (film): 2974, 1714, 1632, 1417, 1220, $1160 \mathrm{~cm}^{-1}$; HRMS$\operatorname{ESI}(m / z)[\mathrm{M}+\mathrm{H}]^{+}$calcd for $\mathrm{C}_{19} \mathrm{H}_{27} \mathrm{~N}_{3} \mathrm{O}_{3} \mathrm{H}, 346.2131$; found, 346.2130.

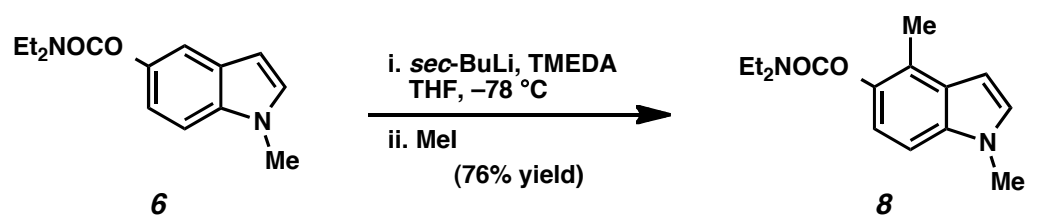

Methyl Carbamate 8. To a solution of indole carbamate $6^{2}(1.0 \mathrm{~g}, 4.06 \mathrm{mmol}, 1.0$ equiv) and TMEDA $\left(0.67 \mathrm{~mL}, 4.47 \mathrm{mmol}, 1.1\right.$ equiv) in THF $(20 \mathrm{~mL})$ at $-78{ }^{\circ} \mathrm{C}$ was added $s e c-B u L i(3.6 \mathrm{~mL}$, $4.47 \mathrm{mmol}, 1.1$ equiv) over $15 \mathrm{~min}$. After stirring for $1 \mathrm{~h}$, methyl iodide $(0.30 \mathrm{~mL}, 4.87 \mathrm{mmol}, 1.2$ equiv) was added dropwise over $1 \mathrm{~min}$ and stirred for $1 \mathrm{~h}$. The reaction was allowed to warm to $23{ }^{\circ} \mathrm{C}$ over $1 \mathrm{~h}$ and quenched with saturated aqueous $\mathrm{NH}_{4} \mathrm{Cl}(10 \mathrm{~mL})$. The reaction mixture was diluted with $\mathrm{H}_{2} \mathrm{O}(20 \mathrm{~mL})$ and EtOAc $(30 \mathrm{~mL})$. The layers were separated, and the aqueous layer was extracted with EtOAc $(3 \times 30 \mathrm{~mL})$. The combined organic layers were washed with brine $(30 \mathrm{~mL})$, dried over $\mathrm{MgSO}_{4}$ and concentrated under reduced pressure. The crude residue was purified by flash chromatography $(7: 1 \rightarrow 5: 1$ Hexanes:EtOAc) to afford the methyl carbamate $8(0.80 \mathrm{~g}, 76 \%$ yield $)$ as a white solid. $\mathrm{R}_{f} 0.30$ (5:1 Hexanes:EtOAc); ${ }^{1} \mathrm{H}$ NMR (500 MHz, $\left.\mathrm{CDCl}_{3}\right): \delta 7.11(\mathrm{~d}, J=8.5,1 \mathrm{H}), 7.03$ $(\mathrm{d}, J=3.0,1 \mathrm{H}), 6.94(\mathrm{~d}, J=8.5,1 \mathrm{H}), 6.46(\mathrm{~d}, J=3.0,1 \mathrm{H}), 3.76(\mathrm{~s}, 3 \mathrm{H}), 3.51(\mathrm{ad}, J=6.0,2 \mathrm{H}), 3.41$ $(\mathrm{ad}, J=6.0,2 \mathrm{H}), 2.37$ (s, 3H), 1.30 (as, 3H), 1.21 (as, 3H); ${ }^{13} \mathrm{C}$ NMR $\left(125 \mathrm{MHz}, \mathrm{CDCl}_{3}\right): \delta 155.1$, 142.8, 134.3, 129.3, 129.1, 121.6, 116.8, 107.1, 99.9, 42.2, 41.9, 33.2, 17.4, 14.5, 12.7; IR (film): 2972 , 1708, 1467, 1418, 1218, $1159 \mathrm{~cm}^{-1}$; HRMS-ESI $(m / z)[\mathrm{M}+\mathrm{Na}]^{+}$calcd for $\mathrm{C}_{15} \mathrm{H}_{20} \mathrm{~N}_{2} \mathrm{O}_{2} \mathrm{Na}, 283.1422$; found, 283.1420 . 


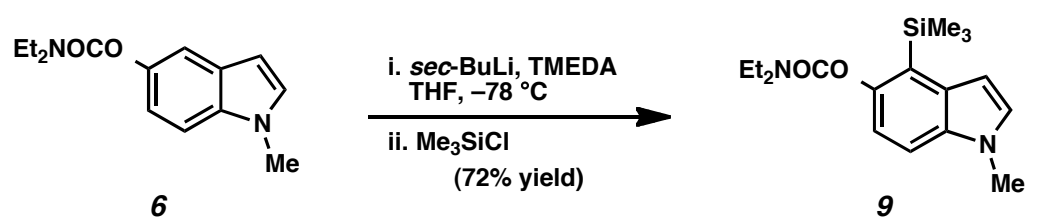

Silyl Carbamate 9. To a solution of indole carbamate $6^{2}$ (1.0 g, $4.06 \mathrm{mmol}, 1.0$ equiv) and TMEDA (0.67 mL, $4.47 \mathrm{mmol}, 1.1$ equiv) in THF $(20 \mathrm{~mL})$ at $-78{ }^{\circ} \mathrm{C}$ was added sec-BuLi (3.6 mL, $4.47 \mathrm{mmol}$, 1.1 equiv) over $15 \mathrm{~min}$. After stirring for $1 \mathrm{~h}, \mathrm{Me}_{3} \mathrm{SiCl}(0.67 \mathrm{~mL}, 4.87 \mathrm{mmol}, 1.2$ equiv) was added dropwise over $1 \mathrm{~min}$ and stirred for $2 \mathrm{~h}$. The reaction was allowed to warm to $23{ }^{\circ} \mathrm{C}$ over 20 min and then quenched with saturated aqueous $\mathrm{NH}_{4} \mathrm{Cl}(10 \mathrm{~mL})$ and $\mathrm{H}_{2} \mathrm{O}(10 \mathrm{~mL})$. The aqueous layer was extracted with EtOAc $(3 \times 30 \mathrm{~mL})$. The combined organic layers were washed with brine $(30 \mathrm{~mL})$, dried over $\mathrm{MgSO}_{4}$ and concentrated under reduced pressure. The crude residue was purified by flash chromatography $(19: 1 \rightarrow 9: 1 \rightarrow 5: 1$ Hexanes:EtOAc) to yield silyl carbamate product $9(0.933 \mathrm{~g}, 72 \%$ yield) as an off-white solid. $\mathrm{R}_{f} 0.20$ (5:1 Hexanes:EtOAc); ${ }^{1} \mathrm{H}$ NMR (500 MHz, $\left.\mathrm{CDCl}_{3}\right): \delta 7.30(\mathrm{~d}, J=$ $8.5,1 \mathrm{H}), 7.09(\mathrm{~d}, J=3.0,1 \mathrm{H}), 6.88(\mathrm{~d}, J=8.5,1 \mathrm{H}), 6.64(\mathrm{dd}, J=3.0,0.5,1 \mathrm{H}), 3.78(\mathrm{~s}, 3 \mathrm{H}), 3.52(\mathrm{q}, J$ $=7.0,2 \mathrm{H}), 3.42(\mathrm{q}, J=7.0,2 \mathrm{H}), 1.28(\mathrm{t}, J=7.0,3 \mathrm{H}), 1.21(\mathrm{q}, J=7.0,3 \mathrm{H}), 0.42(\mathrm{~s}, 9 \mathrm{H}) ;{ }^{13} \mathrm{C} \mathrm{NMR}$ (125 MHz, $\left.\mathrm{CDCl}_{3}\right): \delta 155.6,150.4,133.7,132.7,129.3,122.2,116.9,111.1,102.6,41.8,41.5,33.2$, 14.4, 14.5, 1.1; IR (film): 2972, 1707, 1601, 1401, 1210, $1157 \mathrm{~cm}^{-1} ; \operatorname{HRMS}-E S I(m / z)[\mathrm{M}+\mathrm{Na}]^{+}$calcd for $\mathrm{C}_{17} \mathrm{H}_{26} \mathrm{~N}_{2} \mathrm{O}_{2} \mathrm{ASiNa}$, 341.1661; found, 341.1660 .

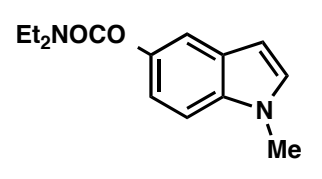

6
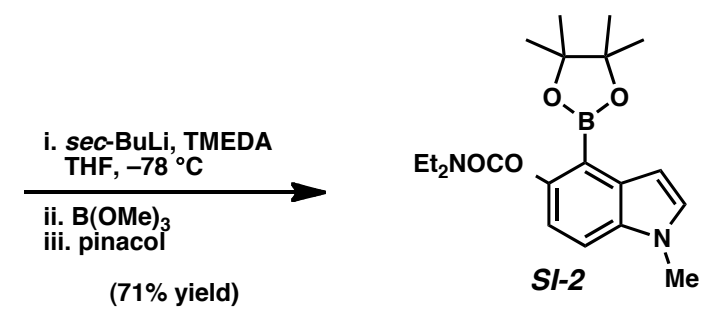

SI-2. To a solution of indole carbamate $\mathbf{6}^{2}(1.0 \mathrm{~g}, 4.06 \mathrm{mmol}, 1.0$ equiv) and TMEDA $(0.67 \mathrm{~mL}, 4.47$ mmol, 1.1 equiv) in THF $(20 \mathrm{~mL})$ at $-78{ }^{\circ} \mathrm{C}$ was added $s e c-B u L i(4.0 \mathrm{~mL}, 4.47 \mathrm{mmol}, 1.1$ equiv) over 15 min. After stirring for $45 \mathrm{~min}$, trimethylborate $(0.54 \mathrm{~mL}, 4.87 \mathrm{mmol}, 1.2$ equiv) was added dropwise and stirred for $1.5 \mathrm{~h}$. The reaction was allowed to warm to $23{ }^{\circ} \mathrm{C}$ over $30 \mathrm{~min}$ and then quenched with saturated aqueous $\mathrm{NH}_{4} \mathrm{Cl}(15 \mathrm{~mL})$ and a drop of $\mathrm{H}_{2} \mathrm{O}$. The reaction mixture was diluted with $\mathrm{H}_{2} \mathrm{O}(30 \mathrm{~mL})$ and EtOAc $(30 \mathrm{~mL})$. The layers were separated and the aqueous layer extracted with EtOAc $(3 \times 50 \mathrm{~mL})$. The combined organic layers were washed with brine $(30 \mathrm{~mL})$, dried over $\mathrm{MgSO}_{4}$ and concentrated under reduced pressure. The crude product was dissolved in dry $\mathrm{MeOH}(40$ $\mathrm{mL})$ and pinacol $(0.53 \mathrm{~g}, 4.47 \mathrm{mmol}, 1.1$ equiv) was added. The solution was evaporated to dryness 
over $10 \mathrm{~min}$. The crude residue was purified by flash chromatography (15:1 Hexanes:Acetone) to generate boronic ester indole carbamate product SI-2 (1.08 g, 71\% yield) as a yellow oil. $\mathrm{R}_{f} 0.25$ (5:1 Hexanes:Acetone); ${ }^{1} \mathrm{H}$ NMR $\left(500 \mathrm{MHz}, \mathrm{CDCl}_{3}\right): \delta 7.33(\mathrm{~d}, J=9.0,1 \mathrm{H}), 7.07(\mathrm{~d}, J=3.0,1 \mathrm{H}), 6.94-$ $6.92(\mathrm{~m}, 2 \mathrm{H}), 3.77(\mathrm{~s}, 3 \mathrm{H}), 3.54(\mathrm{q}, J=7.0,2 \mathrm{H}), 3.40(\mathrm{q}, J=7.0,2 \mathrm{H}), 1.34(\mathrm{~s}, 12 \mathrm{H}), 1.33-1.29(\mathrm{~m}$, $3 \mathrm{H}), 1.20(\mathrm{t}, J=6.0,3 \mathrm{H}) ;{ }^{13} \mathrm{C} \mathrm{NMR}\left(125 \mathrm{MHz}, \mathrm{CDCl}_{3}\right): \delta 155.8,150.8,138.0,134.1,133.8,130.0$, 129.2, 125.4, 116.7, 112.3, 103.5, 83.1, 42.0, 41.6, 33.1, 25.2, 25.0, 21.6, 14.3, 13.7; IR (film): 2976, 2933, 1709, 1412, 1275, 1214, $1162 \mathrm{~cm}^{-1}$; HRMS-ESI $(\mathrm{m} / \mathrm{z})[\mathrm{M}+\mathrm{H}]^{+}$calcd for $\mathrm{C}_{20} \mathrm{H}_{29} \mathrm{BN}_{2} \mathrm{O}_{4} \mathrm{H}$, 373.2303; found, 373.2305 .

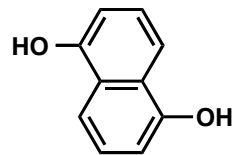

SI-3

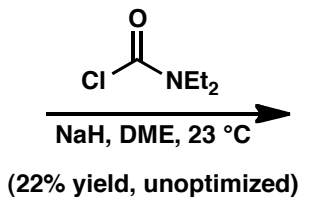

(22\% yield, unoptimized)

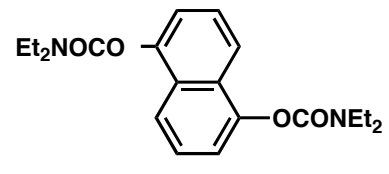

SI-4

SI-4. A round bottom flask was charged with $\mathrm{NaH}(0.60 \mathrm{~g}, 14.98 \mathrm{mmol}, 2.4$ equiv, $60 \%$ dispersion in oil). A solution of 1,5-dihydroxynaphthalene (SI-3) (1.0 g, $6.24 \mathrm{mmol}, 1$ equiv) in DME (25 mL) was added dropwise via cannula to the sodium hydride. Diethylcarbamoyl chloride $(1.50 \mathrm{~mL}, 11.86 \mathrm{mmol}$, 1.9 equiv) was then added dropwise to the reaction vessel. The reaction was allowed to stir for $20 \mathrm{~h}$. The volatiles were removed under reduced pressure and then EtOAc $(30 \mathrm{~mL})$ and $\mathrm{H}_{2} \mathrm{O}(20 \mathrm{~mL})$ were added. The layers were separated, and the organic layer was washed successively with $1 \mathrm{M} \mathrm{KOH} \mathrm{(20}$ $\mathrm{mL})$ and $\mathrm{H}_{2} \mathrm{O}(20 \mathrm{~mL})$. The combined aqueous layers were extracted with EtOAc $(3 \mathrm{x} 50 \mathrm{~mL})$. The combined organic layers were then washed with brine $(10 \mathrm{~mL})$, dried over $\mathrm{MgSO}_{4}$, and concentrated under reduced pressure. The crude residue was purified by flash chromatography (5:1 Benzene:Et $\left.{ }_{2} \mathrm{O}\right)$ to yield biscarbamate naphthalene SI-4 as a red amorphous solid (0.50 g, 22\% yield). $\mathrm{R}_{f} 0.30$ (5:1 Benzene:Et $\left.{ }_{2} \mathrm{O}\right) ;{ }^{1} \mathrm{H}$ NMR $\left(500 \mathrm{MHz}, \mathrm{CDCl}_{3}\right): \delta 7.79(\mathrm{~d}, J=8.5,2 \mathrm{H}), 7.45(\mathrm{t}, J=8.0,2 \mathrm{H}), 7.31(\mathrm{~d}, J=$ $7.5,2 \mathrm{H}), 3.61(\mathrm{q}, J=7.0,4 \mathrm{H}), 3.45(\mathrm{q}, J=7.0,4 \mathrm{H}), 1.38(\mathrm{t}, J=7.0,6 \mathrm{H}), 1.25(\mathrm{t}, J=7.0,6 \mathrm{H}) ;{ }^{13} \mathrm{C}$ NMR (125 MHz, $\mathrm{CDCl}_{3}$ ): $\delta$ 154.2, 147.6, 129.0, 126.0, 118.8. 118.6, 42.5, 42.2, 14.6, 13.6; IR (film): 2975, 1709, 1394, 1242, $1153 \mathrm{~cm}^{-1}$; HRMS-ESI $(\mathrm{m} / \mathrm{z})[\mathrm{M}+\mathrm{Na}]^{+}$calcd for $\mathrm{C}_{20} \mathrm{H}_{26} \mathrm{~N}_{2} \mathrm{O}_{4} \mathrm{Na}, 381.1790$; found, 381.1790 . 

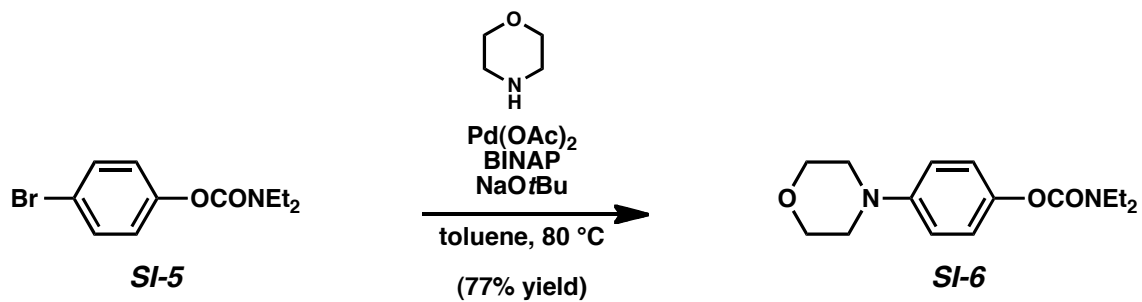

SI-6. A $50 \mathrm{~mL}$ round bottom flask was charged with $\mathrm{Pd}(\mathrm{OAc})_{2}(83.0 \mathrm{mg}, 0.37 \mathrm{mmol}, 10 \mathrm{~mol} \%)$, BINAP (0.24 g, $0.40 \mathrm{mmol}, 11 \mathrm{~mol} \%)$, anhydrous powdered $\mathrm{NaO} t \mathrm{Bu}(0.59 \mathrm{~g}, 5.14 \mathrm{mmol}, 1.4$ equiv), bromide SI-5 $^{3}$ (1.0 g, 3.67 mmol, 1 equiv), morpholine (0.39 mL, $4.4 \mathrm{mmol}, 1.2$ equiv) and a magnetic stir bar, all in a glove box. Subsequently, toluene $(15 \mathrm{~mL})$ that had been rigorously sparged with $\mathrm{N}_{2}$ was added. The vessel was sealed under an atmosphere of argon and then heated at $80{ }^{\circ} \mathrm{C}$ for $24 \mathrm{~h}$. After cooling the reaction vessel to $23{ }^{\circ} \mathrm{C}$, the crude mixture was diluted with $\mathrm{Et}_{2} \mathrm{O}(10 \mathrm{~mL})$, filtered over a plug of celite with additional $\mathrm{Et}_{2} \mathrm{O}(10 \mathrm{~mL})$ and concentrated under reduced pressure. The crude residue was purified by flash chromatography (5:1 Hexanes:EtOAc) to yield aminated carbamate SI-6 (0.7835 g, 77\% yield) as a gray amorphous solid. $\mathrm{R}_{f} 0.10$ (5:1 Hexanes:EtOAc); ${ }^{1} \mathrm{H}$ NMR (500 MHz, $\left.\mathrm{CDCl}_{3}\right): \delta 7.02(\mathrm{~d}, J=9.0,2 \mathrm{H}), 6.89(\mathrm{~d}, J=9.0,2 \mathrm{H}), 3.85(\mathrm{t}, J=4.5,4 \mathrm{H}), 3.42-3.38$ $(\mathrm{m}, 4 \mathrm{H}), 3.10(\mathrm{t}, J=4.5,4 \mathrm{H}), 1.24-1.19(\mathrm{~m}, 6 \mathrm{H}) ;{ }^{13} \mathrm{C} \mathrm{NMR}\left(125 \mathrm{MHz}, \mathrm{CDCl}_{3}\right): \delta$ 154.8, 154.8, 148.9, 145.1, 122.4, 116.8, 67.1, 50.2, 42.3, 41.9, 14.4, 13.5; IR (film): 2971, 2834, 1713, 1512, 1418, 1210 $\mathrm{cm}^{-1}$; HRMS-ESI $(\mathrm{m} / z)[\mathrm{M}+\mathrm{H}]^{+}$calcd for $\mathrm{C}_{15} \mathrm{H}_{22} \mathrm{~N}_{2} \mathrm{O}_{3} \mathrm{H}, 279.1709$; found, 279.1710.
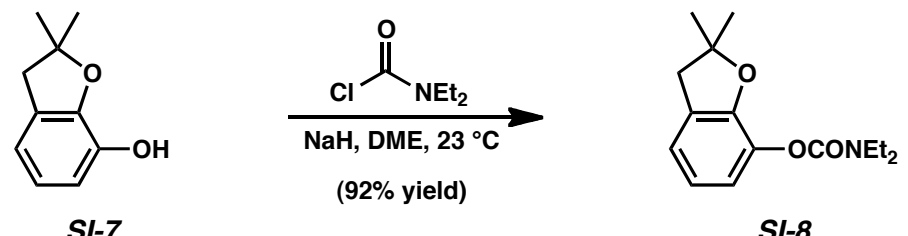

SI-8

SI-8. A round bottom flask was charged with $\mathrm{NaH}(0.88 \mathrm{~g}, 21.92 \mathrm{mmol}, 1.2$ equiv, 60\% dispersion in oil). A solution of dihydrobenzofuranol SI-7 (3.0 mL, $18.27 \mathrm{mmol}, 1$ equiv) in DME (40 mL) was added dropwise via cannula to the sodium hydride. A solution of diethylcarbamoyl chloride $(2.2 \mathrm{~mL}$, $17.36 \mathrm{mmol}, 0.95$ equiv) in DME (30 mL) was then added dropwise via cannula to the reaction vessel. The reaction was stirred at $23{ }^{\circ} \mathrm{C}$ for $45 \mathrm{~h}$. The volatiles were removed under reduced pressure and then $\mathrm{Et}_{2} \mathrm{O}(30 \mathrm{~mL})$ and $\mathrm{H}_{2} \mathrm{O}(20 \mathrm{~mL})$ were added. The layers were separated and the organic layer was washed successively with $1 \mathrm{M} \mathrm{KOH}(20 \mathrm{~mL})$ and $\mathrm{H}_{2} \mathrm{O}(20 \mathrm{~mL})$. The combined aqueous layers were extracted with $\mathrm{Et}_{2} \mathrm{O}(3 \times 20 \mathrm{~mL})$. The combined organic layers were then washed with brine $(20 \mathrm{~mL})$, dried over $\mathrm{MgSO}_{4}$, and evaporated to dryness. The crude residue was purified by flash chromatography 
(7:1 Hexanes:EtOAc) to yield carbamate SI-8 as a clear oil (1.0 g, 92\% yield). $\mathrm{R}_{f} 0.4$ (Benzene); ${ }^{1} \mathrm{H}$ $\operatorname{NMR}\left(400 \mathrm{MHz}, \mathrm{CDCl}_{3}\right): \delta 6.95(\mathrm{dd}, J=7.5,1.5,1 \mathrm{H}), 6.91(\mathrm{ad}, J=8.0,1 \mathrm{H}), 6.76(\mathrm{at}, J=7.5,1 \mathrm{H})$, 3.44-3.38 (m, 4H), $3.01(\mathrm{~s}, 2 \mathrm{H}), 1.47(\mathrm{~s}, 6 \mathrm{H}), 1.26-1.20(\mathrm{~m}, 6 \mathrm{H}) ;{ }^{13} \mathrm{C}$ NMR $\left(125 \mathrm{MHz}, \mathrm{CDCl}_{3}\right): \delta$ 153.8, 150.6, 135.4, 129.3, 121.9, 121.8, 119.9, 87.8, 43.1, 42.3, 42.1, 28.2, 14.1, 13.4; IR (film): 2974, 2934, 1718, 1416, 1152, $1052 \mathrm{~cm}^{-1}$; HRMS-ESI $(\mathrm{m} / z)[\mathrm{M}+\mathrm{Na}]^{+}$calcd for $\mathrm{C}_{15} \mathrm{H}_{21} \mathrm{NO}_{3} \mathrm{Na}, 286.1419$; found, 286.1420 .
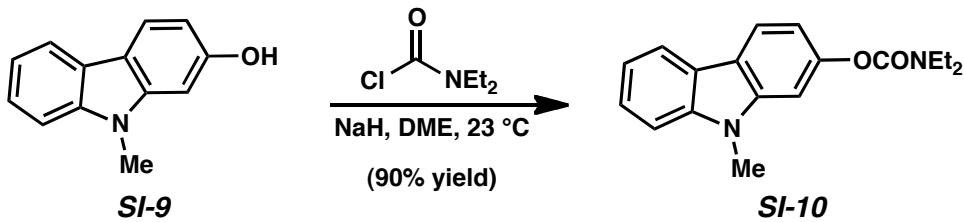

SI-10. A round bottom flask was charged with $\mathrm{NaH}(122 \mathrm{mg}, 3.04 \mathrm{mmol}, 1.2$ equiv, 60\% dispersion in oil). A solution of 2-hydroxycarbazole SI-9 (500 mg, $2.54 \mathrm{mmol}, 1$ equiv) in DME (10 mL) was added dropwise via cannula to the sodium hydride. Diethylcarbamoyl chloride $(0.31 \mathrm{~mL}, 2.41 \mathrm{mmol}, 0.95$ equiv) was then added dropwise to the reaction vessel. The reaction was stirred at $23{ }^{\circ} \mathrm{C}$ for $13 \mathrm{~h}$. The reaction was diluted with $\mathrm{H}_{2} \mathrm{O}(10 \mathrm{~mL})$ and the volatiles were removed under reduced pressure. EtOAc (30 mL) and $\mathrm{H}_{2} \mathrm{O}(20 \mathrm{~mL})$ were added and the layers were separated. The organic layer was washed successively with $1 \mathrm{M} \mathrm{KOH}(20 \mathrm{~mL})$ and $\mathrm{H}_{2} \mathrm{O}(20 \mathrm{~mL})$. The combined aqueous layers were extracted with EtOAc $(3 \times 30 \mathrm{~mL})$. The combined organic layers were then washed with brine $(20 \mathrm{~mL})$, dried over $\mathrm{MgSO}_{4}$, and concentrated under reduced pressure. The crude residue was purified by flash chromatography (2:1 Hexanes:EtOAc) to generate carbazole carbamate SI-10 as a white solid (0.643 g, 90\% yield). $\mathrm{R}_{f} 0.15$ (5:1 Hexanes:EtOAc); ${ }^{1} \mathrm{H}$ NMR $\left(500 \mathrm{MHz}, \mathrm{CDCl}_{3}\right): \delta 8.06(\mathrm{~d}, J=8.0,1 \mathrm{H}), 8.04$ $(\mathrm{d}, J=8.5,1 \mathrm{H}), 7.46-7.44(\mathrm{~m}, 1 \mathrm{H}), 7.39(\mathrm{~d}, J=8.0,1 \mathrm{H}), 7.25-7.21(\mathrm{~m}, 2 \mathrm{H}), 6.99(\mathrm{dd}, J=8.5,2.0$, $1 \mathrm{H}), 3.81(\mathrm{~s}, 3 \mathrm{H}), 3.52(\mathrm{q}, J=7.0,2 \mathrm{H}), 3.44(\mathrm{q}, J=7.0,2 \mathrm{H}), 1.32(\mathrm{t}, J=7.0,3 \mathrm{H}), 1.25(\mathrm{t}, J=7.0,3 \mathrm{H})$; ${ }^{13} \mathrm{C}$ NMR (125 MHz, $\left.\mathrm{CDCl}_{3}\right): \delta 154.8,150.3,141.6,141.6,125.4,122.7,120.7,120.3,120.2,119.2$, 113.3, 108.5, 102.2, 42.4, 42.0, 29.4, 14.5, 13.6; IR (film): 3055, 2978, 1710, 1602, 1417, 1266, 1154 $\mathrm{cm}^{-1}$; HRMS-ESI $(\mathrm{m} / \mathrm{z})[\mathrm{M}+\mathrm{Na}]^{+}$calcd for $\mathrm{C}_{18} \mathrm{H}_{20} \mathrm{~N}_{2} \mathrm{O}_{2} \mathrm{Na}, 319.1422$; found, 319.1421 . 


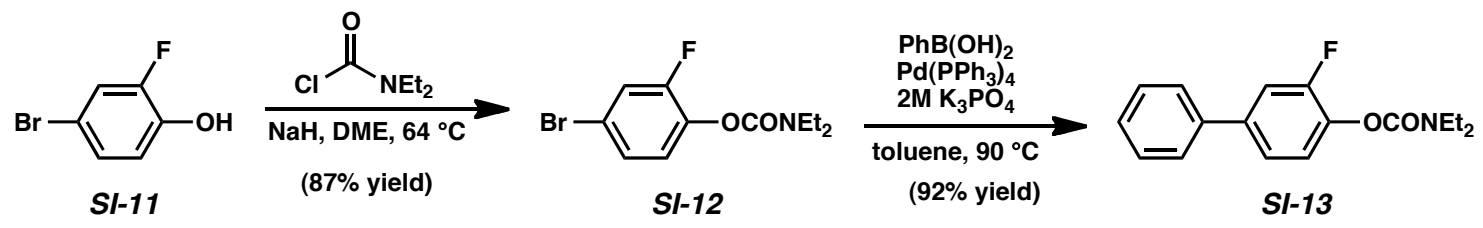

SI-13. A round bottom flask was charged with $\mathrm{NaH}(0.188 \mathrm{~g}, 4.70 \mathrm{mmol}, 1.2$ equiv, 60\% dispersion in oil). A solution of phenol SI-11 (0.43 mL, $6.24 \mathrm{mmol}, 1$ equiv) in DME ( $7 \mathrm{~mL})$ was added dropwise via cannula to the sodium hydride. A solution of diethylcarbamoyl chloride $(0.47 \mathrm{~mL}, 3.73 \mathrm{mmol}, 0.95$ equiv) in DME (9 $\mathrm{mL})$ was then added dropwise via cannula to the reaction vessel. The reaction was stirred at $64{ }^{\circ} \mathrm{C}$ for $1.5 \mathrm{~h}$. The reaction was stopped and cooled to $23{ }^{\circ} \mathrm{C}$. The volatiles were removed under reduced pressure and then $\mathrm{Et}_{2} \mathrm{O}(30 \mathrm{~mL})$ and $\mathrm{H}_{2} \mathrm{O}(20 \mathrm{~mL})$ were added. The layers were separated, and the organic layer was washed successively with $1 \mathrm{M} \mathrm{KOH}(20 \mathrm{~mL})$ and $\mathrm{H}_{2} \mathrm{O}(20 \mathrm{~mL})$. The combined aqueous layers were extracted with $\mathrm{Et}_{2} \mathrm{O}(3 \times 20 \mathrm{~mL})$. The combined organic layers were then washed with brine $(20 \mathrm{~mL})$, dried over $\mathrm{MgSO}_{4}$, and evaporated to dryness. The crude residue was purified by flash chromatography (7:1 Hexanes:EtOAc) to yield carbamate SI-12 (1.0 g, 87\% yield) as a clear oil. Spectral data match those previously reported. ${ }^{4}$

A $20 \mathrm{~mL}$ scintillation vial was charged with a magnetic stir bar, $\mathrm{K}_{3} \mathrm{PO}_{4}(2.2 \mathrm{~mL}, 2 \mathrm{M}$ aqueous) and toluene $(4.3 \mathrm{~mL})$ and the biphasic solution was sparged with $\mathrm{N}_{2}$ for $1 \mathrm{~h}$. To the solution was added bromide SI-12 (250 mg, $0.86 \mathrm{mmol}, 1$ equiv), phenylboronic acid (126 mg, $1.03 \mathrm{mmol}, 1.2 \mathrm{equiv}$ ) and $\mathrm{Pd}\left(\mathrm{PPh}_{3}\right)_{4}(149 \mathrm{mg}, 0.13 \mathrm{mmol}, 15 \mathrm{~mol} \%)$ and the resulting mixture was sparged with $\mathrm{N}_{2}$ for $10 \mathrm{~min}$. The vial was sealed with a Teflon-coated screw-cap and heated at $90{ }^{\circ} \mathrm{C}$ for $18 \mathrm{~h}$. After cooling to 23 ${ }^{\circ} \mathrm{C}, \mathrm{CH}_{2} \mathrm{Cl}_{2}(10 \mathrm{~mL})$ and $\mathrm{Na}_{2} \mathrm{SO}_{4}$ were added and the mixture was allowed to stand for $30 \mathrm{~min}$. The crude mixture was then filtered over silica and concentrated under reduced pressure. The crude residue was purified by flash chromatography $(15: 1 \rightarrow 10: 1$ Hexanes: EtOAc) to yield fluorobiphenyl carbamate SI-13 (140 mg, 92\% yield) as a clear oil. $\mathrm{R}_{f} 0.05$ (Hexanes); ${ }^{1} \mathrm{H}$ NMR $\left(500 \mathrm{MHz}, \mathrm{CDCl}_{3}\right): \delta$ $7.56-7.51(\mathrm{~m}, 2 \mathrm{H}), 7.46-7.41(\mathrm{~m}, 2 \mathrm{H}), 7.38-7.31(\mathrm{~m}, 3 \mathrm{H}), 7.26(\mathrm{t}, J=8.0,1 \mathrm{H}), 3.48(\mathrm{q}, J=7.0,2 \mathrm{H})$, $3.42(\mathrm{q}, J=7.0,2 \mathrm{H}), 1.29(\mathrm{t}, J=7.0,3 \mathrm{H}), 1.23(\mathrm{t}, J=7.0,3 \mathrm{H}) ;{ }^{13} \mathrm{C} \mathrm{NMR}\left(125 \mathrm{MHz}, \mathrm{CDCl}_{3}\right): \delta 155.6$, $153.7,153.3,134.0,139.9,139.6,128.9,127.7,127.1,124.4,122.8,115.2,115.1,42.6,42.1,14.1$, 13.3; IR (film): 2976, 1714, 1471, 1367, $1141 \mathrm{~cm}^{-1}$; HRMS-ESI $(m / z)[\mathrm{M}+\mathrm{H}]^{+}$calcd for $\mathrm{C}_{17} \mathrm{H}_{18} \mathrm{FNO}_{2} \mathrm{H}, 288.1400$; found 288.1399. 


\section{B. Reduction of Aryl Carbamates}
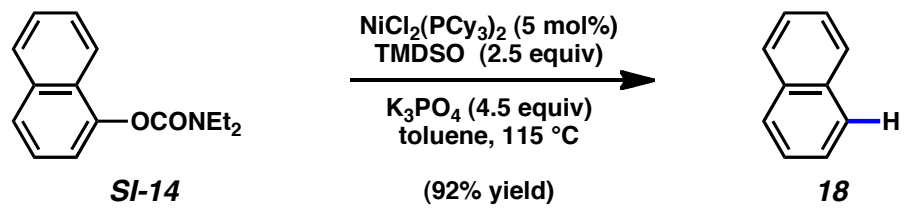

Representative Procedure (reduction of naphthylcarbamate SI-14, Figure 5 is used as an example). Naphthalene (18, Figure 5). A 4-mL vial was charged with anhydrous powdered $\mathrm{K}_{3} \mathrm{PO}_{4}$ ( $0.379 \mathrm{~g}, 1.8 \mathrm{mmol}, 4.5$ equiv) and a magnetic stir bar. The vial and contents were flame-dried under reduced pressure, then allowed to cool under $\mathrm{N}_{2}$. Naphthyl carbamate SI-14 (96.8 mg, $0.4 \mathrm{mmol}, 1$ equiv) and $\mathrm{NiCl}_{2}\left(\mathrm{PCy}_{3}\right)_{2}(13.8 \mathrm{mg}, 0.02 \mathrm{mmol}, 5 \mathrm{~mol} \%)$ were added. Subsequently, tetramethyldisiloxane (TMDSO) $(0.17 \mathrm{~mL}, 1.0 \mathrm{mmol}, 2.5$ equiv) and toluene $(1.5 \mathrm{~mL})$ were added. The septum cap was replaced with a Teflon-lined screw cap. The heterogeneous mixture was stirred at $115{ }^{\circ} \mathrm{C}$ for $15 \mathrm{~h}$. The reaction vessel was cooled to $23{ }^{\circ} \mathrm{C}$. The reaction mixture was diluted with EtOAc $(5 \mathrm{~mL})$, filtered over a pad of celite (eluted with an additional $5 \mathrm{~mL}$ of EtOAc), and evaporated to dryness. The crude residue was purified by flash chromatography (100\% Hexanes) to yield deoxygenated product 18 (47.2 $\mathrm{mg}, 92 \%$ yield) as a white amorphous solid. $\mathrm{R}_{f} 0.52$ (100\% Hexanes). Spectral data match those previously reported. ${ }^{5}$

Any modifications of the conditions shown in this representative procedure are specified in the following schemes, which depict all of the results shown in Figures 2, 3, 4, and 5.
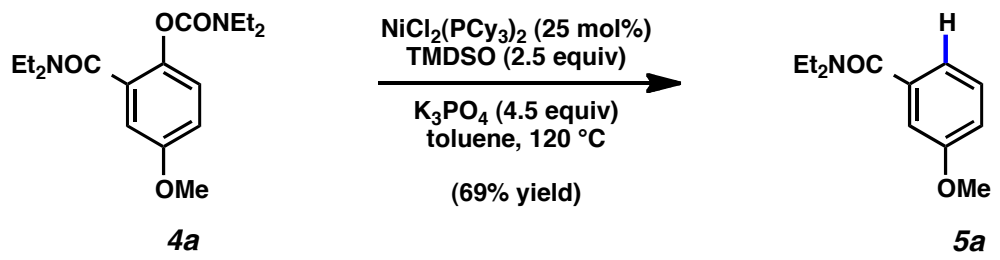

Amide 5a (Figure 2). Purification by flash chromatography (3:1 Hexanes:EtOAc) generated deoxygenated product 5a (91\% yield) as a clear oil. $\mathrm{R}_{f} 0.28$ (1:1 Hexanes:EtOAc). Spectral data match those previously reported. ${ }^{6}$ 

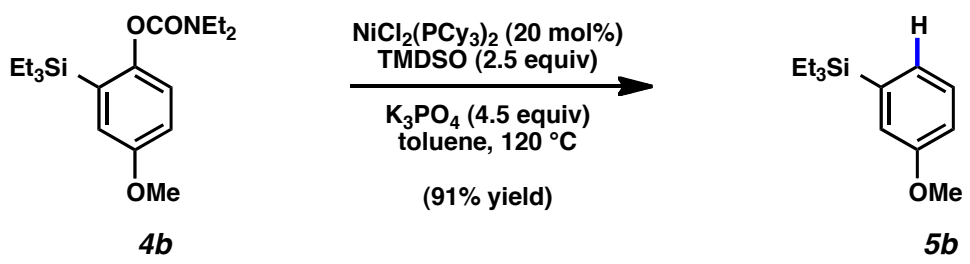

Silane 5b (Figure 2). Purification by flash chromatography (19:1 Hexanes:EtOAc) generated deoxygenated product $\mathbf{5 b}$ (91\% yield) as a clear oil. $\mathrm{R}_{f} 0.44$ (19:1 Hexanes:EtOAc). Spectral data match those previously reported. ${ }^{7}$
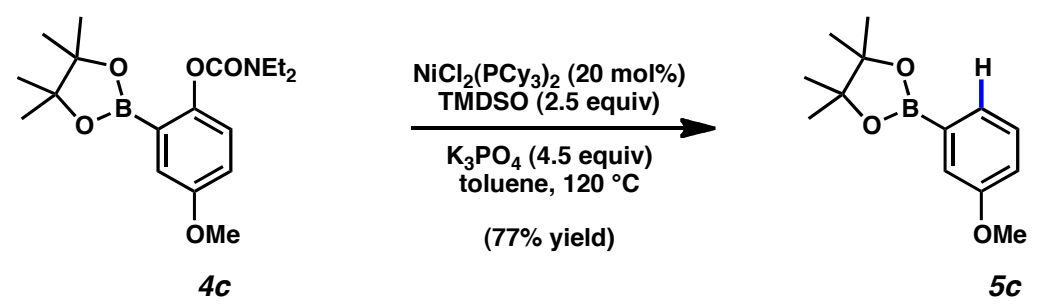

Boronic Ester 5c (Figure 2). Purification by flash chromatography (19:1 Hexanes:EtOAc) afforded deoxygenated product $5 \mathbf{c}$ (77\% yield) as a clear oil. $\mathrm{R}_{f} 0.30$ (19:1 Hexanes:EtOAc). Spectral data match those previously reported. ${ }^{8}$
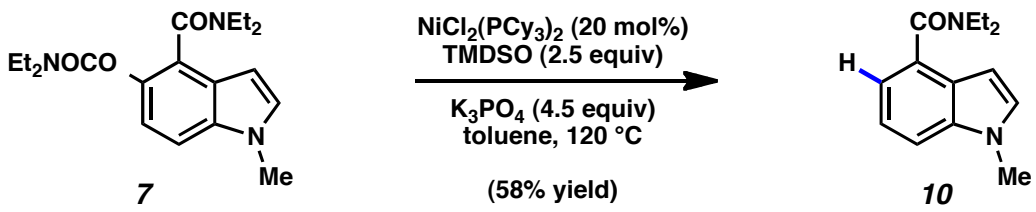

Amide Indole 10 (Figure 3). Purification by flash chromatography (7:1 Hexanes:Acetone) yielded deoxygenated product 10 (58\% yield) as a pale green solid. $\mathrm{R}_{f} 0.09$ (5:1 Hexanes:EtOAc); ${ }^{1} \mathrm{H}$ NMR $\left(500 \mathrm{MHz}, \mathrm{CDCl}_{3}\right): \delta 7.33(\mathrm{ad}, J=8.5,1 \mathrm{H}), 7.22$ (at, $\left.J=7.5,1 \mathrm{H}\right), 7.09-7.07(\mathrm{~m}, 2 \mathrm{H}), 6.44$ (dd, $J=$ 3.0, 0.5, 1H), 3.81 (s, 3H), 3.65 (as, $2 \mathrm{H}), 3.22$ (as, $2 \mathrm{H}), 1.31$ (as, $3 \mathrm{H}), 1.02$ (as, $3 \mathrm{H}) ;{ }^{13} \mathrm{C}$ NMR $(125$ $\left.\mathrm{MHz}, \mathrm{CDCl}_{3}\right): \delta 170.9,136.9,129.7,129.7,125.6,121.4,117.2,109.9,99.9,43.2,38.9,33.1,14.6$, 13.3; IR (film): 2972, 1624, 1427, 1288, $1113 \mathrm{~cm}^{-1}$; HRMS-ESI $(m / z)[\mathrm{M}+\mathrm{H}]^{+}$calcd for $\mathrm{C}_{14} \mathrm{H}_{18} \mathrm{~N}_{2} \mathrm{OH}, 231.1497$; found, 231.1495 . 

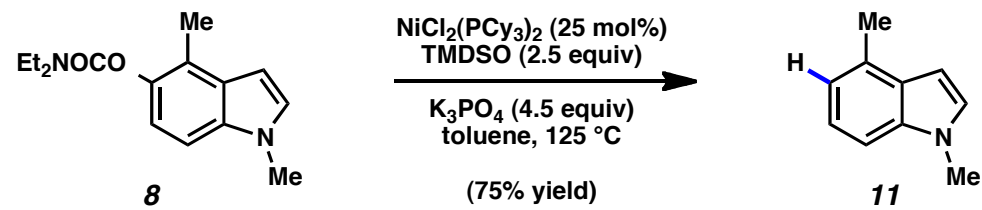

Methylindole 11 (Figure 3). Purification by flash chromatography (20:1 Hexanes:EtOAc) generated deoxygenated product 11 (75\% yield) as a light yellow liquid. $\mathrm{R}_{f} 0.42$ (20:1 Hexanes:EtOAc). Spectral data match those previously reported. ${ }^{14}$
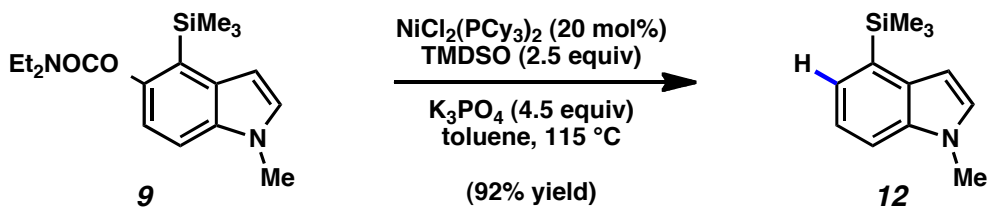

Silylindole 12 (Figure 3). Purification by flash chromatography (5:1 Hexanes:EtOAc) yielded deoxygenated product 12 (92\% yield) as a pale green solid. $\mathrm{R}_{f} 0.47$ (5:1 Hexanes:EtOAc); ${ }^{1} \mathrm{H}$ NMR $\left(500 \mathrm{MHz}, \mathrm{CDCl}_{3}\right): \delta 7.36(\mathrm{ad}, J=8.0,1 \mathrm{H}), 7.29-7.22(\mathrm{~m}, 2 \mathrm{H}), 7.11(\mathrm{~d}, J=3.5,1 \mathrm{H}), 6.62(\mathrm{dd}, J=$ 2.5, 1.0, 1H), $3.87(\mathrm{~s}, 3 \mathrm{H}), 0.41(\mathrm{~s}, 9 \mathrm{H}) ;{ }^{13} \mathrm{C} \mathrm{NMR}\left(125 \mathrm{MHz}, \mathrm{CDCl}_{3}\right): \delta$ 135.6, 132.4, 132.2, 128.7 , 125.4, 121.2, 110.4, 102.1, 32.9, 0.42; IR (film): 3044, 2956, 1518, 1406, $1248 \mathrm{~cm}^{-1}$; HRMS-ESI (m/z) $[\mathrm{M}+\mathrm{H}]^{+}$calcd for $\mathrm{C}_{12} \mathrm{H}_{17} \mathrm{NSiH}, 204.1208$; found, 204.1213.
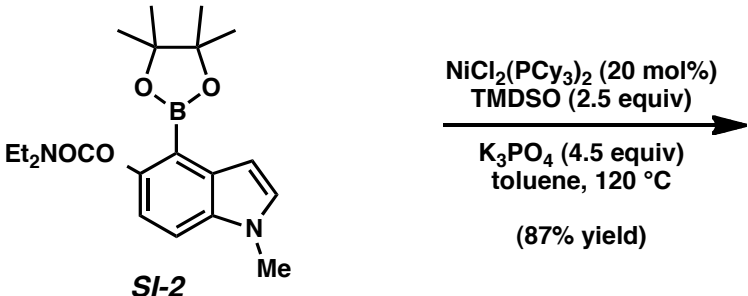

Boronic Ester Indole 13 (Figure 4). Purification by flash chromatography (10:1 Hexanes:EtOAc) generated deoxygenated product $\mathbf{1 3}$ (87\% yield) as a white solid. $\mathrm{R}_{f} 0.37$ (10:1 Hexanes:EtOAc). Spectral data match those previously reported. ${ }^{9}$ 

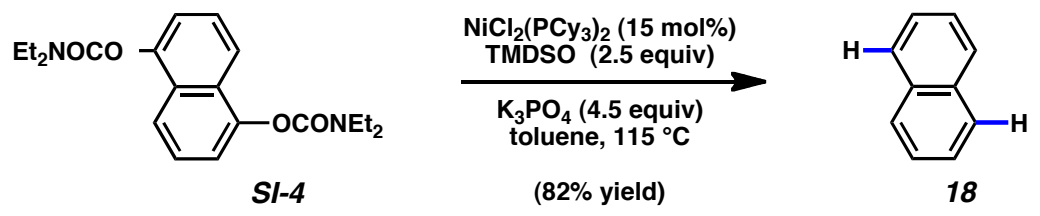

Naphthalene (18, Figure 5). Purification by flash chromatography (100\% Hexanes) yielded deoxygenated product 18 (82\% yield) as a white amorphous solid. $\mathrm{R}_{f} 0.52$ (100\% Hexanes). Spectral data match those previously reported. ${ }^{5}$
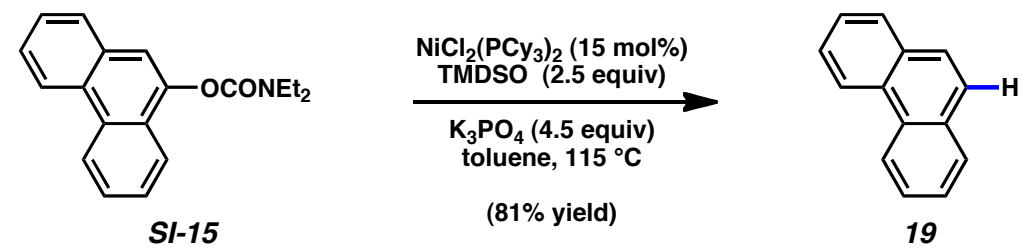

Phenanthrene (19, Figure 5). Purification by flash chromatography (100\% Hexanes) afforded deoxygenated product 19 (81\% yield) as a white amorphous solid. $\mathrm{R}_{f} 0.35$ (100\% Hexanes). Spectral data match those previously reported. ${ }^{5}$
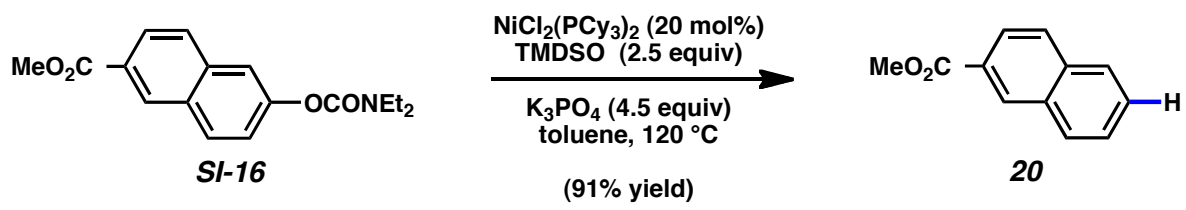

Naphthyl Ester 20 (Figure 5). Purification by flash chromatography (9:1 Hexanes:EtOAc) afforded deoxygenated product 20 (91\% yield) as a white amorphous solid. $\mathrm{R}_{f} 0.37$ (9:1 Hexanes:EtOAc). Spectral data match those previously reported. ${ }^{5}$ 

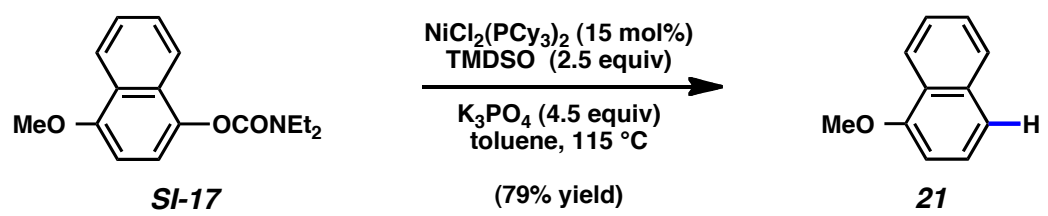

Naphthyl Ether 21 (Figure 5). Purification by flash chromatography (19:1 Hexanes:EtOAc) afforded deoxygenated product 21 (79\% yield) as a white solid. $\mathrm{R}_{f} 0.48$ (19:1 Hexanes:EtOAc). Spectral data match those previously reported. ${ }^{10}$
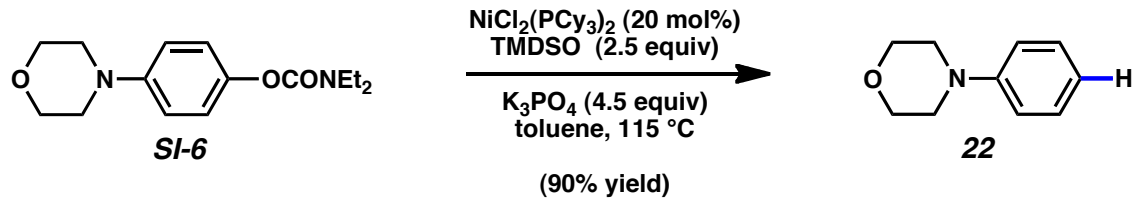

Arylamine 22 (Figure 5). Purification by flash chromatography (9:1 Hexanes:EtOAc) afforded deoxygenated product 22 (90\% yield) as a white amorphous solid. $\mathrm{R}_{f} 0.29$ (9:1 Hexanes:EtOAc). Spectral data match those previously reported. ${ }^{11}$
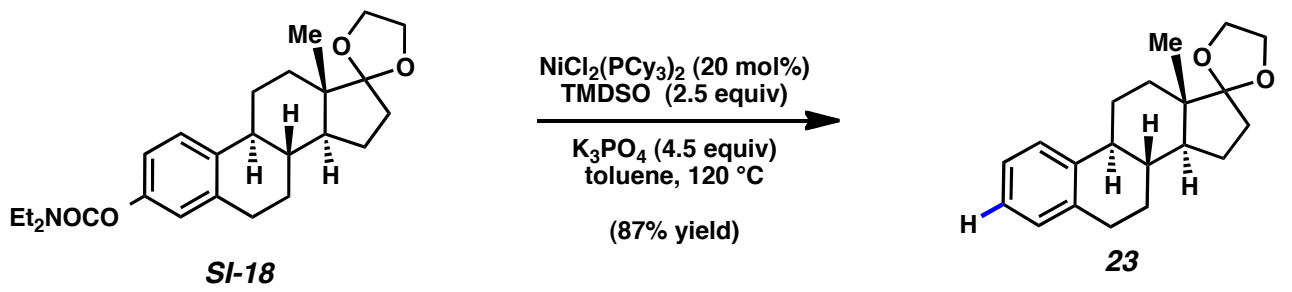

Estrone 23 (Figure 5). Purification by flash chromatography (10:1 Hexanes:EtOAc) generated deoxygenated product 23 (87\% yield) a white solid. $\mathrm{R}_{f} 0.48$ (10:1 Hexanes:EtOAc). Spectral data match those previously reported. ${ }^{12}$ 


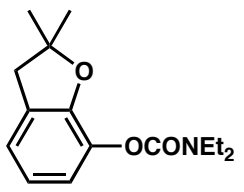

SI-8

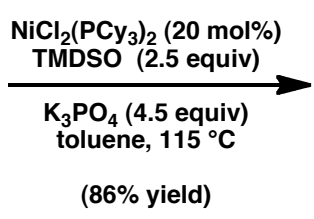

( $86 \%$ yield)

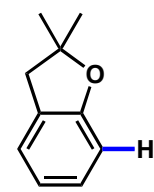

24

Dihydrobenzofuran 24 (Figure 5). Purification by flash chromatography (10:1 Hexanes:EtOAc) afforded deoxygenated product 24 (86\% yield) as a pale yellow oil. $\mathrm{R}_{f} 0.52$ (10:1 Benzene:Et $\left.{ }_{2} \mathrm{O}\right)$. Spectral data match those previously reported. ${ }^{13}$

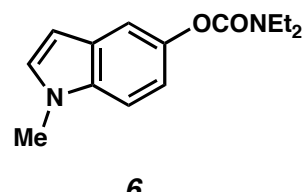

6

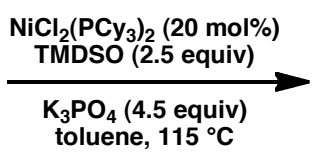

(79\% yield)

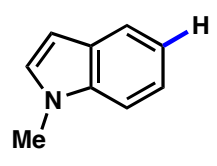

25

Indole 25 (Figure 5). Purification by flash chromatography (7:1 Hexanes:EtOAc) yielded deoxygenated product 25 (79\% yield) as a light yellow liquid. $\mathrm{R}_{f} 0.53$ (7:1 Hexanes:EtOAc). Spectral data match those previously reported. ${ }^{14}$
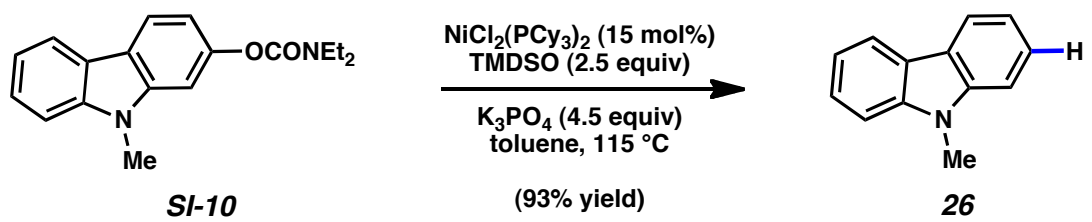

Carbazole 26 (Figure 5). Purification by flash chromatography (10:1 Hexanes:EtOAc) yielded deoxygenated product 26 (93\% yield) as a white solid. $\mathrm{R}_{f} 0.48$ (10:1 Hexanes:EtOAc). Spectral data match those previously reported. ${ }^{5}$ 

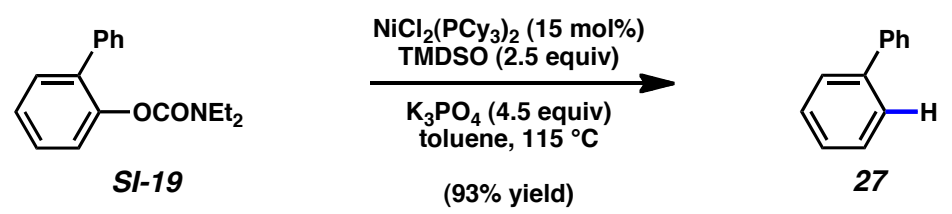

Biphenyl (27, Figure 5). Purification by flash chromatography (9:1 Hexanes:EtOAc) afforded deoxygenated product 27 (93\% yield) as a white solid. $\mathrm{R}_{f} 0.62$ (9:1 Hexanes:EtOAc). Spectral data match those previously reported. ${ }^{5}$
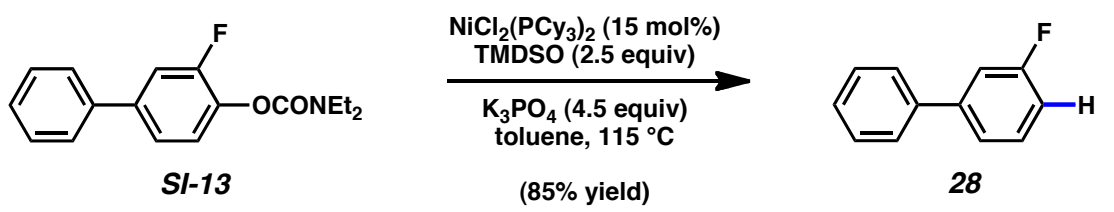

Flurobiphenyl (28, Figure 5). Purification by flash chromatography (100\% Hexanes) yielded deoxygenated product 28 (85\% yield) as a white amorphous solid. $\mathrm{R}_{f} 0.50$ (100\% Hexanes). Spectral data match those previously reported. ${ }^{15}$ 


\section{Cross Coupling Approaches to Ipso and Cine Substituted Products}
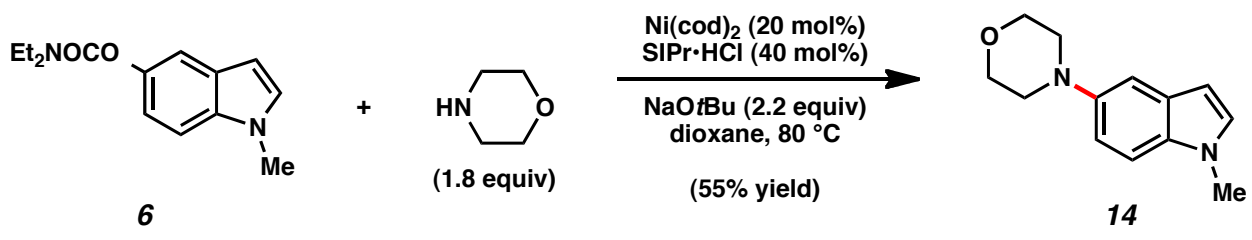

5-Morpholine Indole 14. A $20 \mathrm{~mL}$ scintillation vial was charged with $\mathrm{Ni}(\operatorname{cod})_{2}(27.5 \mathrm{mg}, 0.1 \mathrm{mmol}$, $20 \mathrm{~mol} \%$ ), SIPr $\bullet \mathrm{HCl}(85.4 \mathrm{mg}, 0.2 \mathrm{mmol}, 40 \mathrm{~mol} \%$ ), anhydrous powdered $\mathrm{NaO} t \mathrm{Bu}(105.7 \mathrm{mg}, 1.1$ mmol, 2.2 equiv), and a magnetic stir bar, all in a glove box. Subsequently, a solution of carbamate substrate 6 (123.2 mg, $0.50 \mathrm{mmol}, 1$ equiv) and morpholine (79.0 $\mu \mathrm{L}, 0.9 \mathrm{mmol}, 1.8$ equiv) in dioxane $(2.5 \mathrm{~mL})$ was added. The vessel was removed from the glove box and then heated to $80{ }^{\circ} \mathrm{C}$ for $3 \mathrm{~h}$. After cooling the reaction vessel to $23{ }^{\circ} \mathrm{C}$ and concentrating under reduced pressure, the crude residue was loaded onto a silica gel column $(2.5 \times 10 \mathrm{~cm})$ and purified by flash chromatography $(6: 1: 1$ Benzene: $\mathrm{Et}_{2} \mathrm{O}: \mathrm{CH}_{2} \mathrm{Cl}_{2}$ ) to yield aminated product $14\left(47.6 \mathrm{mg}, 55 \%\right.$ yield) as a white solid. $\mathrm{R}_{f} 0.21$ (10:1:1 Benzene: $\mathrm{Et}_{2} \mathrm{O}: \mathrm{CH}_{2} \mathrm{Cl}_{2}$ ). Spectral data match those previously reported. ${ }^{11}$
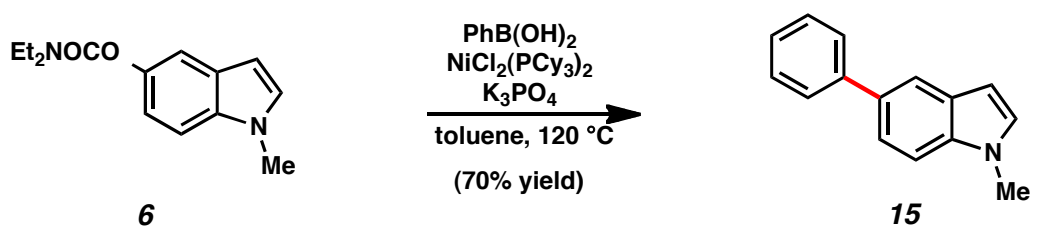

5-Phenylindole 15. A 4-mL vial was charged with anhydrous powdered $\mathrm{K}_{3} \mathrm{PO}_{4}(611 \mathrm{mg}, 2.88 \mathrm{mmol}$, 7.2 equiv) and a magnetic stir bar. The vial and the contents were flame-dried under reduced pressure and then allowed to cool under $\mathrm{N}_{2}$. Phenyl boronic acid (195 mg, $1.6 \mathrm{mmol}, 4.5$ equiv), $\mathrm{NiCl}_{2}\left(\mathrm{PCy}_{3}\right)_{2}$ (27.6 mg, $0.04 \mathrm{mmol}, 10 \mathrm{~mol} \%$ ), and indole carbamate 6 (98.5 mg, $0.4 \mathrm{mmol}, 1$ equiv) were added. The vial was then evacuated and backfilled with $\mathrm{N}_{2}$. Toluene $(1.4 \mathrm{~mL})$ was added and the vial was sealed with a Teflon-lined screw cap and stirred at $23{ }^{\circ} \mathrm{C}$ for $1 \mathrm{~h}$. The heterogeneous mixture was then heated at $120{ }^{\circ} \mathrm{C}$ for $14 \mathrm{~h}$. The reaction vessel was allowed to cool to $23{ }^{\circ} \mathrm{C}$. The mixture was diluted with EtOAc $(5 \mathrm{~mL})$ and filtered over a pad of silica (eluted with an additional $5 \mathrm{~mL}$ of EtOAc). The crude residue was purified by flash chromatography (20:1 Hexanes:EtOAc) to yield coupled product 
15 (88.0 mg, 70\% yield) as a white solid. $\mathrm{R}_{f} 0.53$ (5:1 Hexanes:EtOAc). Spectral data match those previously reported. $^{1 \text { a }}$
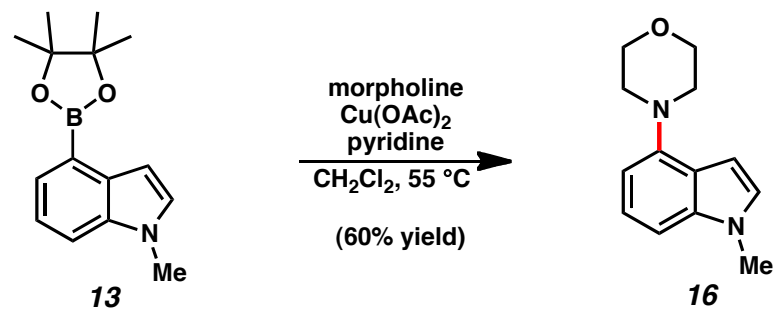

4-Morpholine Indole 16. A 4-mL dram vial equipped with a magnetic stir bar was flame-dried under reduced pressure and backfilled with $\mathrm{N}_{2}$. After cooling to $23{ }^{\circ} \mathrm{C}$, the indole boronic ester $13(0.050 \mathrm{~g}$, $0.194 \mathrm{mmol}, 1$ equiv) and copper acetate $(0.212 \mathrm{~g}, 1.167 \mathrm{mmol}, 6$ equiv) were added to the vial. Morpholine (0.050 mL, $0.583 \mathrm{mmol}, 3$ equiv), pyridine $\left(0.063 \mathrm{~mL}, 0.778 \mathrm{mmol}, 4\right.$ equiv) and $\mathrm{CH}_{2} \mathrm{Cl}_{2}$ $(0.5 \mathrm{~mL})$ were then added to the solids. The septum cap was replaced with a Teflon-coated cap and the reaction was stirred at $55{ }^{\circ} \mathrm{C}$ for $2 \mathrm{~d}$. The reaction vessel was removed from the heating block and cooled to $23{ }^{\circ} \mathrm{C}$. The solution was loaded directly onto a silica gel column and purified by flash chromatography (5:1 hexanes:EtOAc) to yield 4-morpholine indole $16(0.025 \mathrm{~g}, 60 \%$ yield) as a light yellow solid. $\mathrm{R}_{f} 0.42$ (5:1 Hexanes:EtOAc); ${ }^{1} \mathrm{H}$ NMR $\left(500 \mathrm{MHz}, \mathrm{CDCl}_{3}\right): \delta 7.17(\mathrm{t}, J=8.0,1 \mathrm{H}), 7.04$ $(\mathrm{d}, J=8.0,1 \mathrm{H}), 7.02(\mathrm{~d}, J=3.0,1 \mathrm{H}), 6.61(\mathrm{~d}, J=8.0,1 \mathrm{H}), 6.48(\mathrm{~d}, J=3.0,1 \mathrm{H}), 3.9(\mathrm{t}, J=5.0,4 \mathrm{H})$, $3.79(\mathrm{~s}, 3 \mathrm{H}), 3.26(\mathrm{t}, J=5.0,4 \mathrm{H}) ;{ }^{13} \mathrm{C} \mathrm{NMR}\left(125 \mathrm{MHz}, \mathrm{CDCl}_{3}\right): \delta 145.8,138.0,127.5,122.4,121.7$, 106.3, 104.5, 99.5, 67.8, 52.0, 33.2; IR (film): 2963, 2858, 1575, 1498, 1235, $1117 \mathrm{~cm}^{-1}$; HRMS-ESI $(m / z)[\mathrm{M}+\mathrm{H}]^{+}$calcd for $\mathrm{C}_{13} \mathrm{H}_{16} \mathrm{~N}_{2} \mathrm{OH}, 217.1341$; found, 217.1347 .
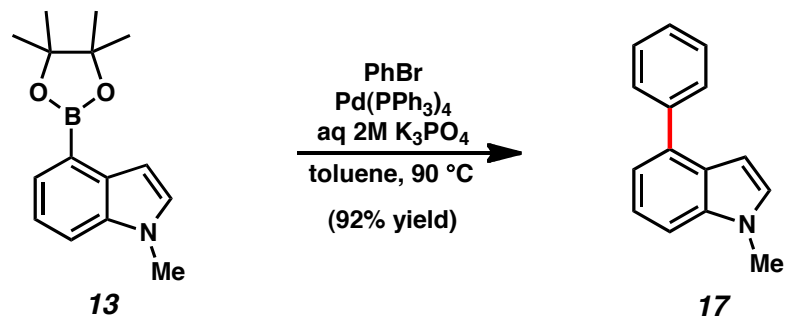

4-Phenylindole 17. A $20 \mathrm{~mL}$ scintillation vial was charged with a magnetic stir bar, $\mathrm{K}_{3} \mathrm{PO}_{4}(3 \mathrm{~mL}, 2$ $\mathrm{M}$ aqueous) and toluene $(1.5 \mathrm{~mL})$. The biphasic solution was then sparged with $\mathrm{N}_{2}$ for $1 \mathrm{~h}$. To the solution was added indole boronic ester 13 (150 mg, $0.583 \mathrm{mmol}, 1$ equiv), phenylboronic acid (123 
mg, 1.167 mmol, 2 equiv) and $\mathrm{Pd}\left(\mathrm{PPh}_{3}\right)_{4}(101 \mathrm{mg}, 0.088 \mathrm{mmol}, 15 \mathrm{~mol} \%)$ and the resulting mixture was sparged with $\mathrm{N}_{2}$ for $10 \mathrm{~min}$. The vial was sealed with a Teflon-coated screw-cap and heated at 90 ${ }^{\circ} \mathrm{C}$ for $14 \mathrm{~h}$. After cooling to $23{ }^{\circ} \mathrm{C}, \mathrm{CH}_{2} \mathrm{Cl}_{2}(5 \mathrm{~mL})$ and $\mathrm{Na}_{2} \mathrm{SO}_{4}$ were added and the mixture was allowed to stand for $30 \mathrm{~min}$. The crude mixture was then filtered over silica and concentrated under reduced pressure. The crude residue was purified by flash chromatography (7:1 Hexanes:EtOAc) to yield 4-phenylindole 17 as a light yellow oil (112 mg, 92\% yield). $\mathrm{R}_{f} 0.41$ (7:1 Hexanes:EtOAc); ${ }^{1} \mathrm{H}$ $\operatorname{NMR}\left(500 \mathrm{MHz}, \mathrm{CDCl}_{3}\right): \delta 7.72(\mathrm{~d}, J=7.5,2 \mathrm{H}), 7.50(\mathrm{t}, J=7.5,2 \mathrm{H}), 7.40-7.32(\mathrm{~m}, 3 \mathrm{H}), 7.22(\mathrm{dd}, J$ $=6.5,1.5,1 \mathrm{H}), 7.12(\mathrm{~d}, J=3.5,1 \mathrm{H}), 6.80(\mathrm{~d}, J=3.0,1 \mathrm{H}) 3.85(\mathrm{~s}, 3 \mathrm{H}) ;{ }^{13} \mathrm{C} \mathrm{NMR}\left(125 \mathrm{MHz}, \mathrm{CDCl}_{3}\right)$ : ठ 141.4, 137.2, 134.5, 129.2, 128.8, 128.5, 127.0, 126.7, 121.9, 119.3, 108.5, 100.4, 32.8; IR (film): 3053, 2909, 1603, 1513, 1413, $1286 \mathrm{~cm}^{-1}$; HRMS-ESI $(\mathrm{m} / z)[\mathrm{M}+\mathrm{H}]^{+}$calcd for $\mathrm{C}_{15} \mathrm{H}_{13} \mathrm{NOH}$, 208.1126; found 208.1128. 


\section{References}

${ }^{1}$ a) Quasdorf, K. W.; Riener, M.; Petrova, K.; Garg, N. K. J. Am. Chem. Soc. 2009, 131, 17748-17749. b) Fu, J.-M.; Snieckus, V. Can. J. Chem. 2000, 78, 905-919. c) Sengupta, S.; Leite, M.; Raslan, D. S.; Quesnelle, C.; Snieckus, V. J. Org. Chem. 1992, 57, 4066-4068. d) van Doorn, A. R.; Bos, M.; Harkema, S.; van Eerden, J.; Verboom, W.; Reinhoudt, D. N. J. Org. Chem. 1991, 69, 2371-2380. e) Zhao, Z.; Snieckus, V. Org. Lett. 2005, 7, 2523-2526. f) Sibi, M. P.; Snieckus, V. J. Org. Chem. 1983, 48, 1935-1937.

${ }^{2}$ Mesganaw, T.; Silberstein, A. L.; Ramgren, S. D.; Fine Nathel, N. F.; Hong, X.; Liu, P.; Garg, N. K. Chem. Sci. 2011, 2, 1766-1771.

${ }^{3}$ Haag, B. A.; Samann, C.; Jana, A.; Knochel, P. Angew. Chem. Int. Ed. 2011, 50, 7290-7294.

${ }^{4}$ Takao, N.; Komaru, A.; Kubota, N.; Takeuchi, Y. (Sony Corp.; Japan, ADEKA Corp.). Jpn. Kokai Tokkyo Koho JP 2002260730 A2 20020913, 2002.

${ }^{5}$ Tobisu, M.; Yamakawa, K.; Shimasaki, T.; Chatani, N. Chem. Commun. 2011, 47, 2946-2948.

${ }^{6}$ Kesenheimer, C.; Kalogerakis, A.; Mebner, A.; Groth, U. Chem. Eur. J. 2010, 16, 8805-8821.

${ }^{7}$ Yamanoi, Y.; Nishihara, H. J. Org. Chem. 2008, 73, 6671-6678.

${ }^{8}$ Zhu, W.; Ma, D. Org. Lett. 2006, 8, 261-263.

${ }^{9}$ Stadlwieser, J. F.; Dambaur, M. E. Helv. Chim. Acta 2006, 89, 936-946.

${ }^{10}$ Zeidan, T. A.; Manoharan, M.; Alabugin, I. V. J. Org. Chem. 2006, 71, 954-961.

${ }^{11}$ Ramgren, S. D.; Silberstein, A. L.; Yang, Y.; Garg, N. K. Angew. Chem. Int. Ed. 2011, 50, 2171-2173.

${ }^{12}$ Birch, A. J.; Cross, P. E.; Connor, D. T.; Subba Rao, G. S. J. Chem. Soc. C. 1966, 54-56.

${ }^{13}$ Wang, X.; Lu, Y.; Dai, H.-X.; Yu, J.-Q. J. Am. Chem. Soc. 2010, 132, 12203-12205.

${ }^{14}$ Schiffner, J. A.; Wöste, T. H.; Oestreich, M. Eur. J. Org. Chem. 2010, 174-182.

${ }^{15}$ Kumar, M. R.; Park, K.; Lee, S. Adv. Synth. Catal. 2010, 352, 3255-3266. 
Mesganaw et al.: Cine Substitution of Arenes Supporting Information - S22

\section{${ }^{1}$ H NMR Spectra}



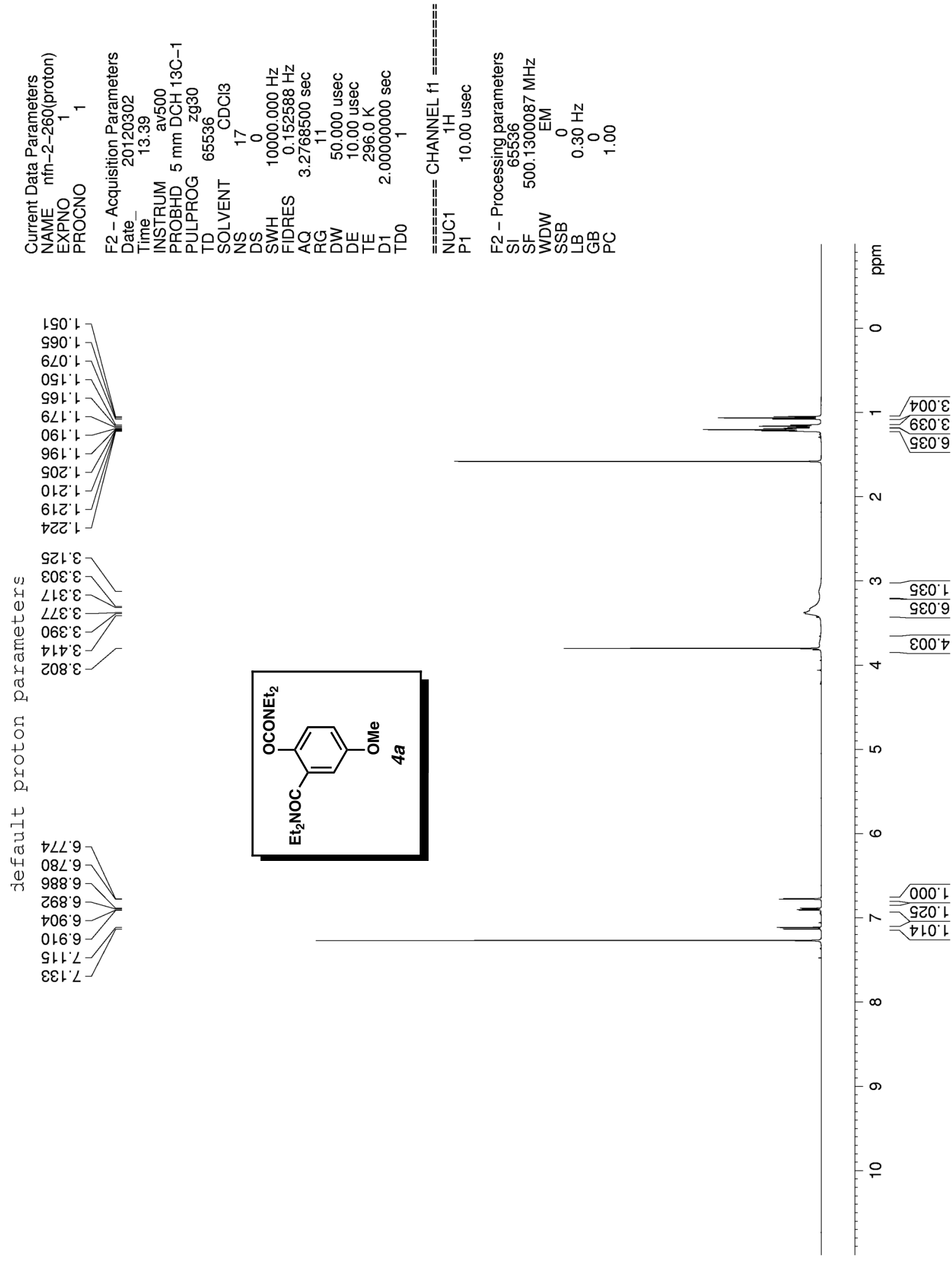


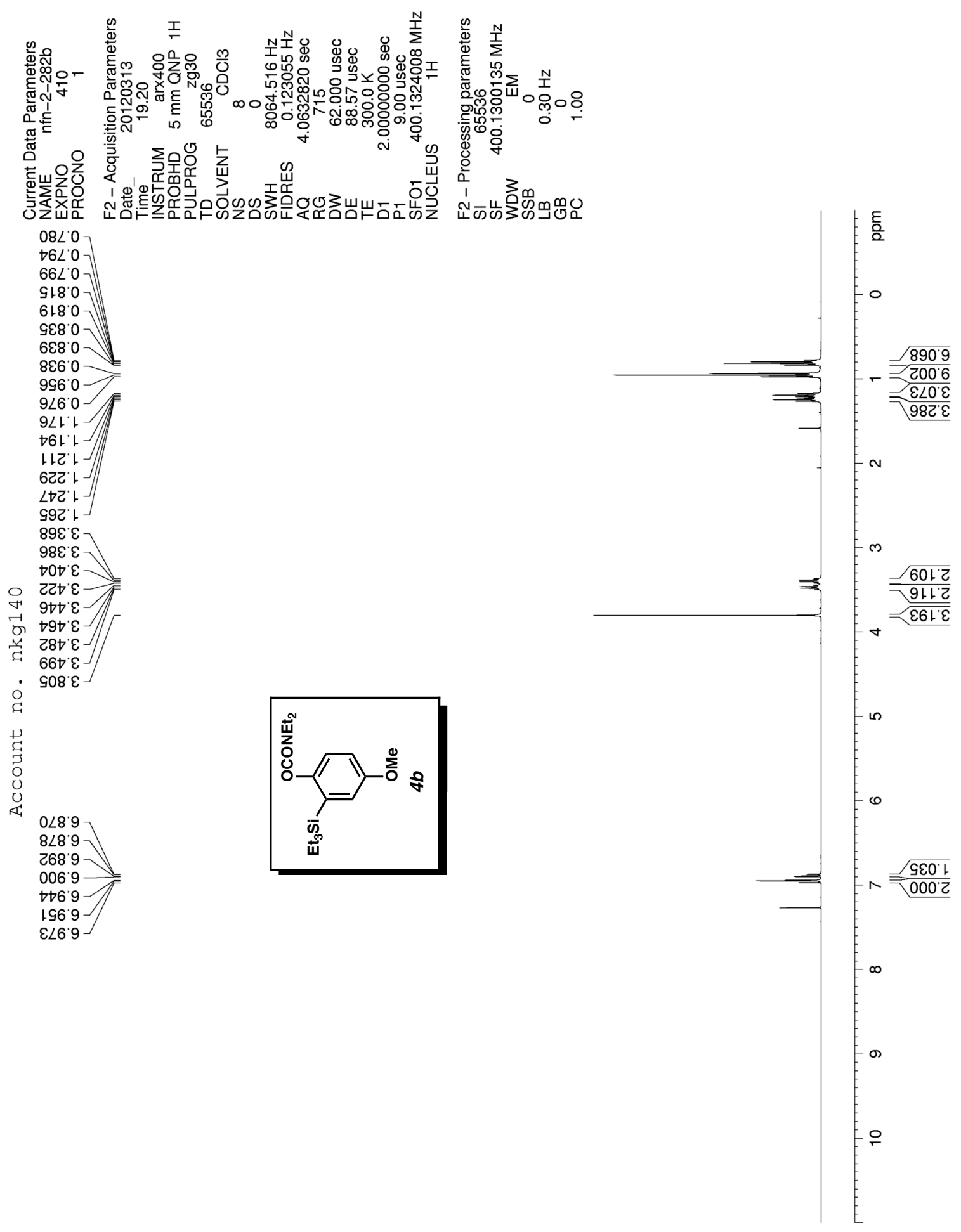



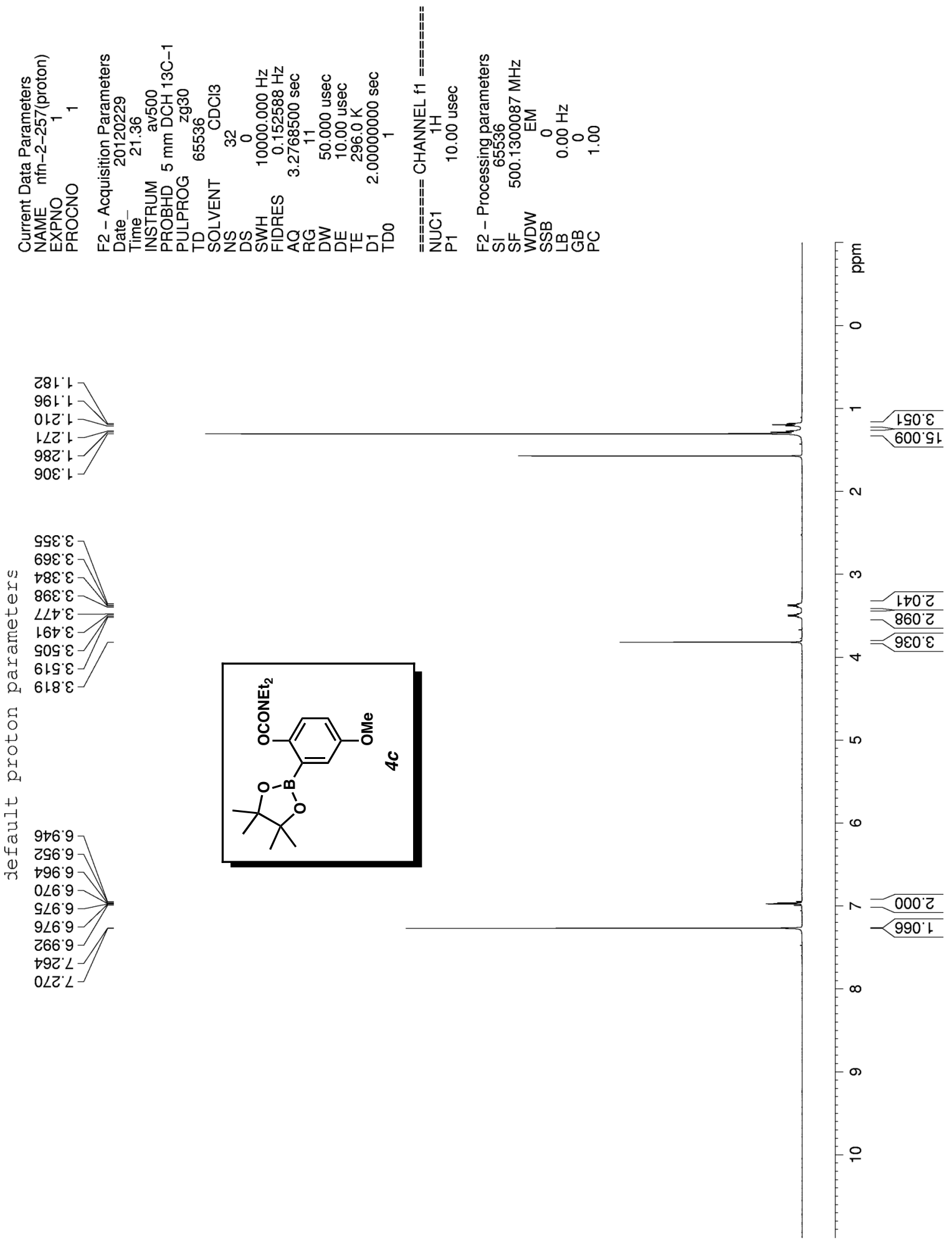

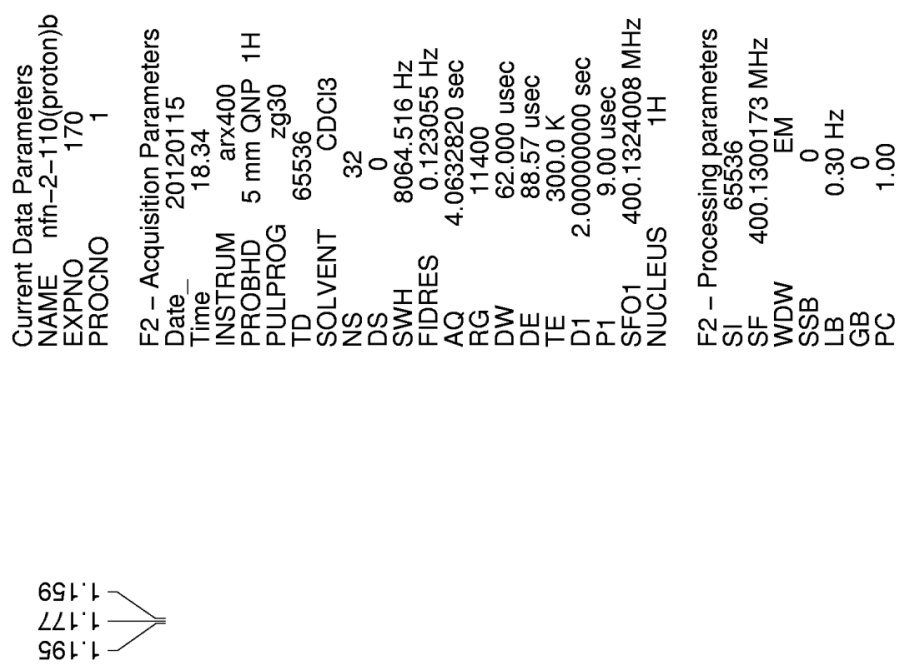

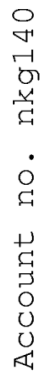

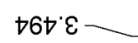

$\varepsilon \varepsilon 9$.

$69 L^{\circ} \varepsilon-$

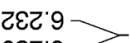

$6 \varepsilon 2.9$

506.9

$\angle 26.9$

$1+0$.

$8+0 \mathrm{~L}$

$\angle t Z \angle$

$\downarrow 96^{\circ} L$
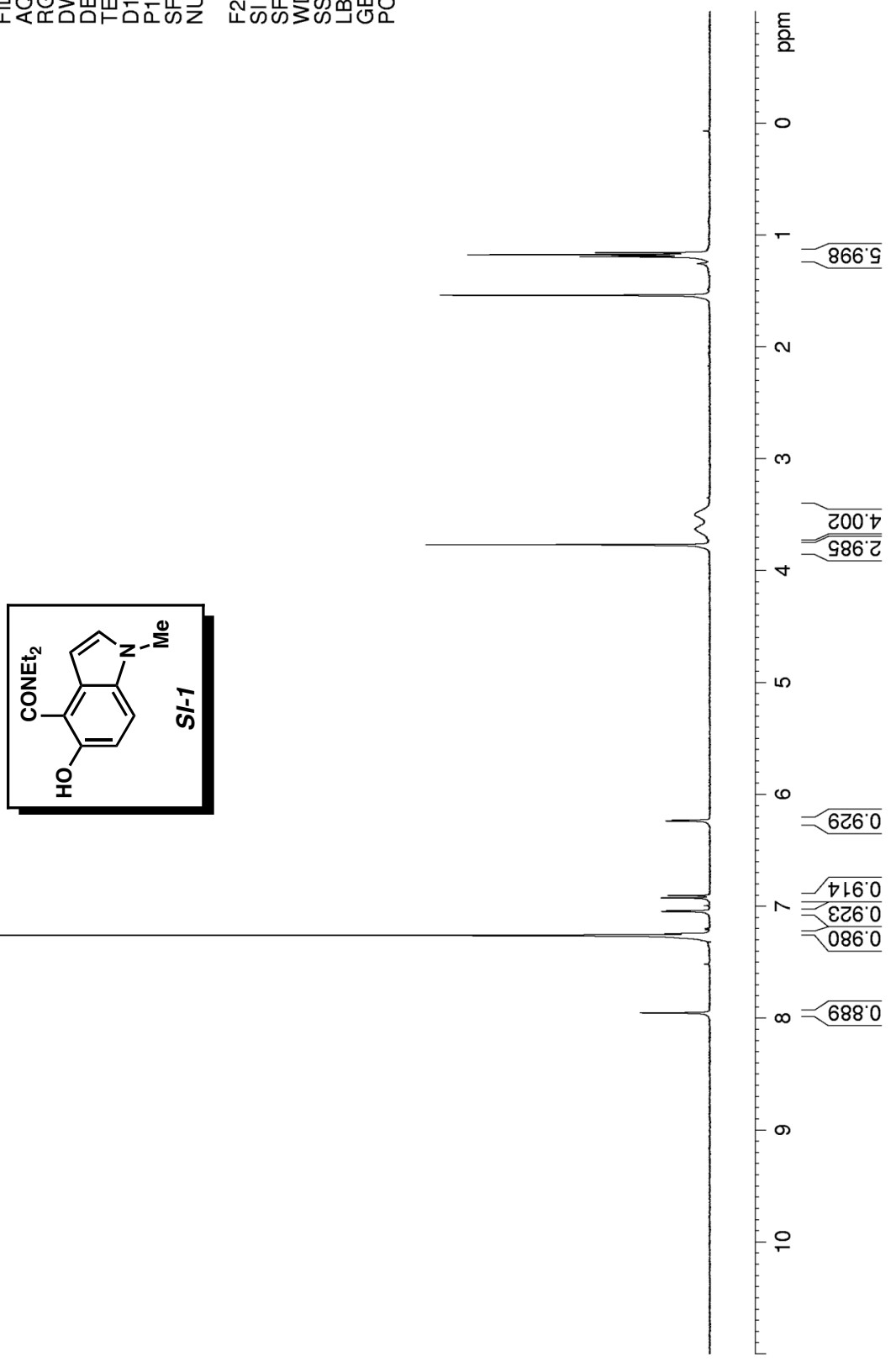


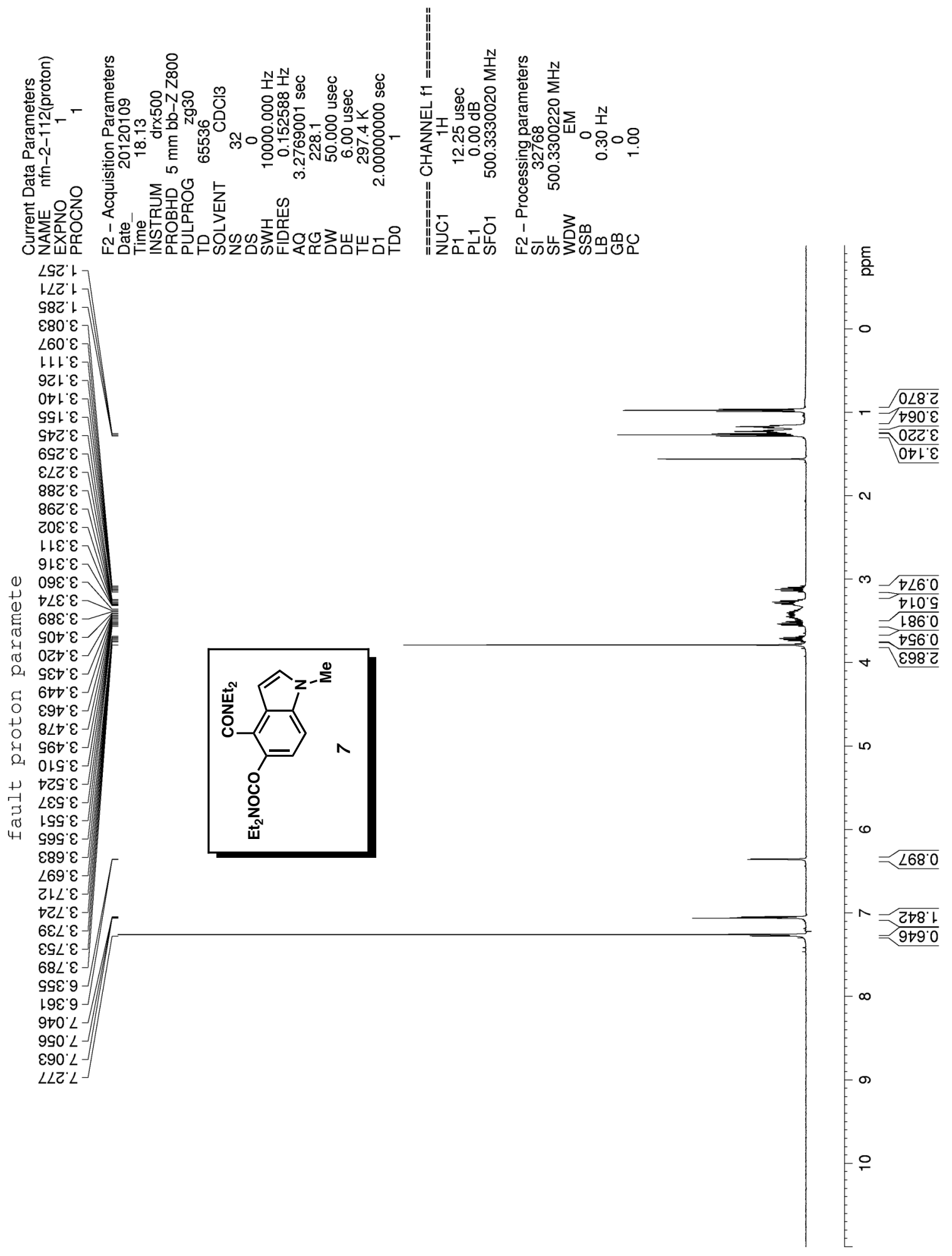



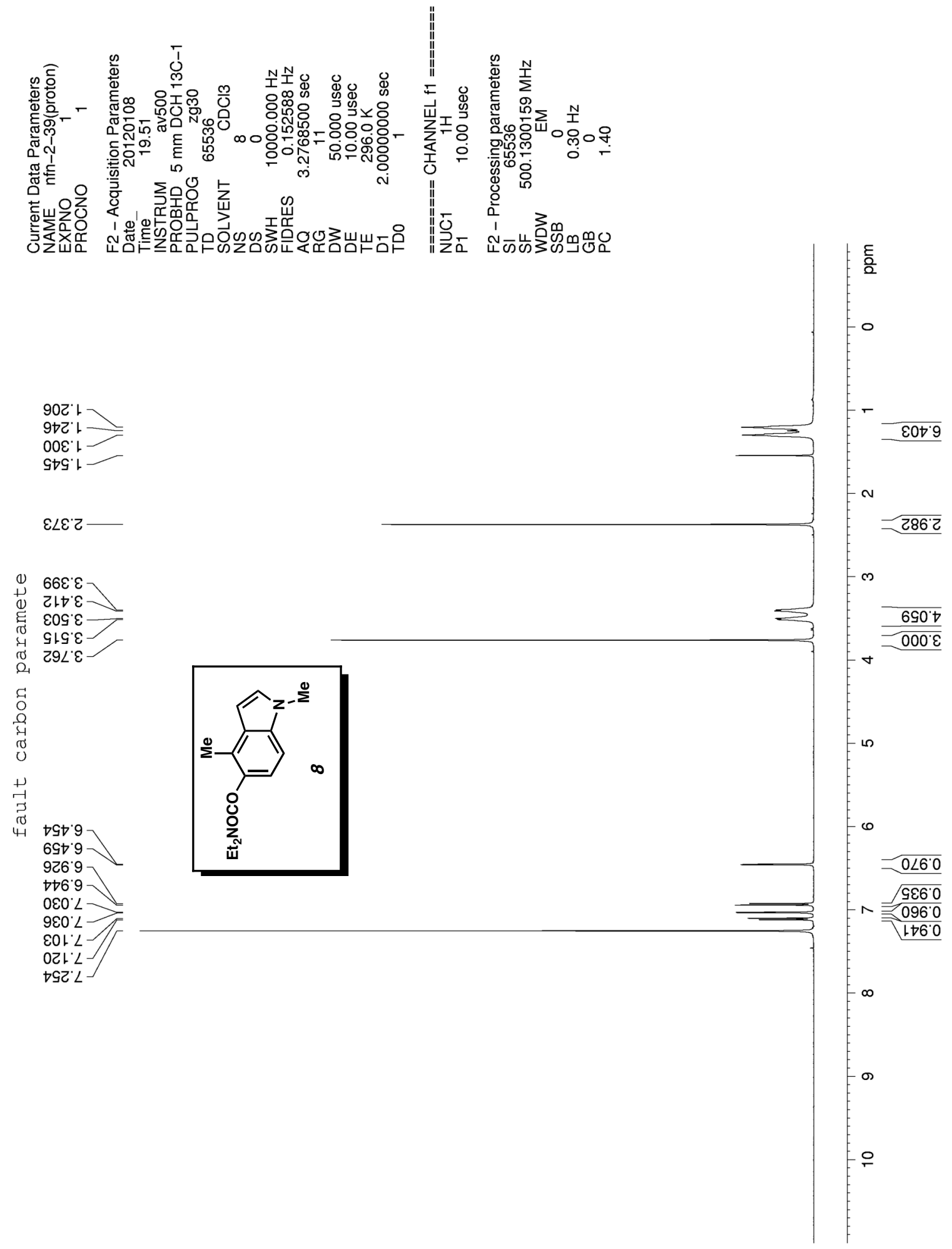

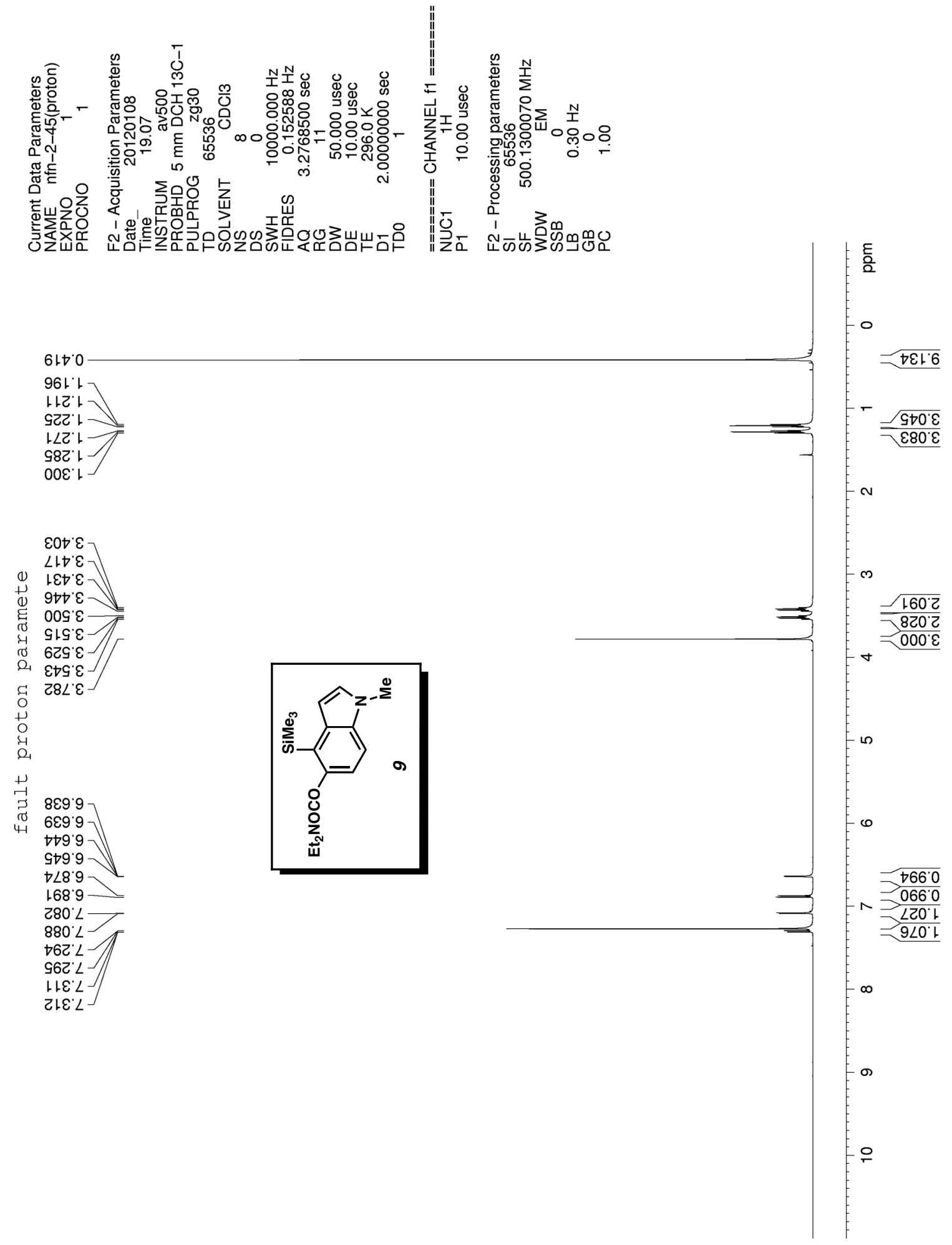

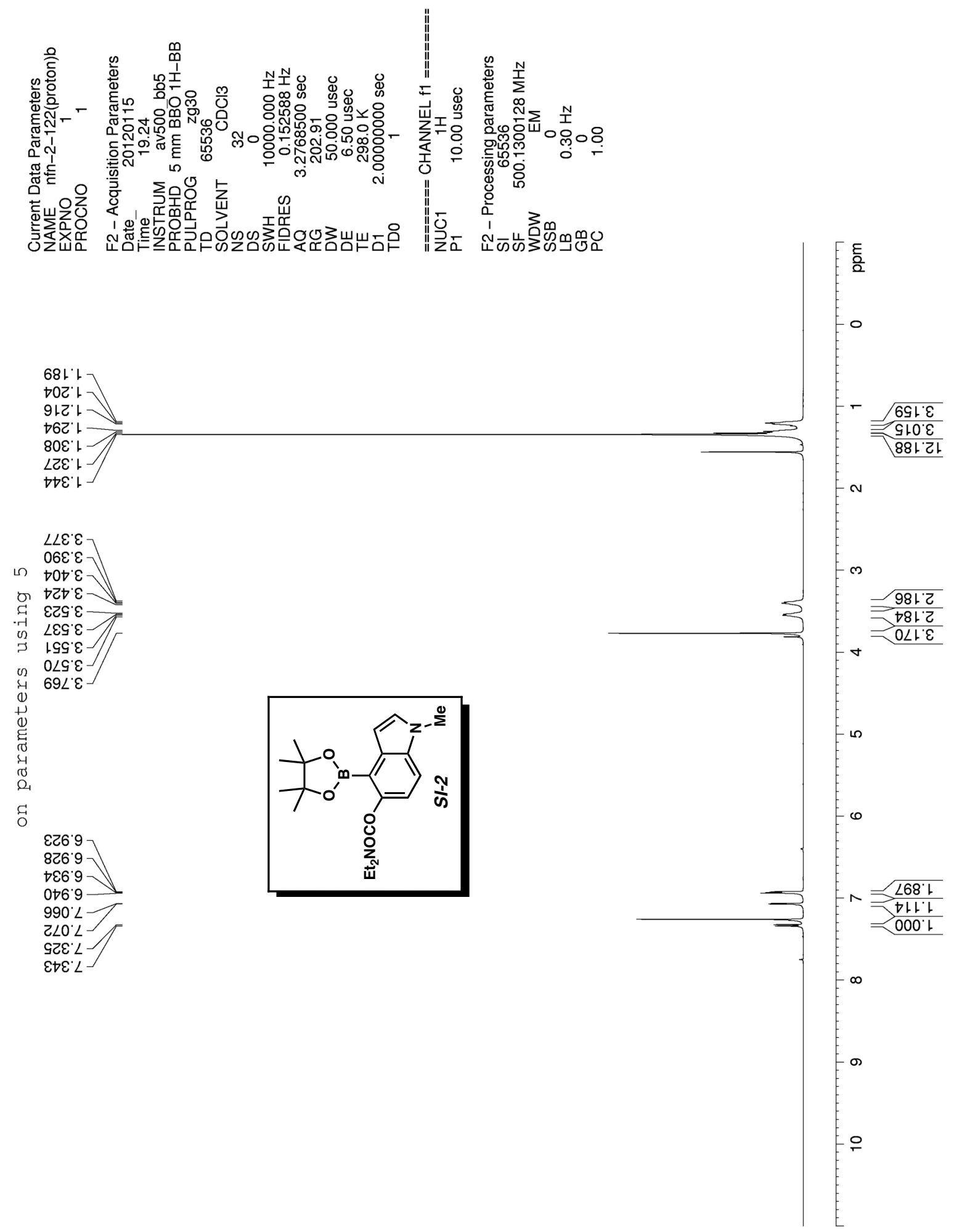

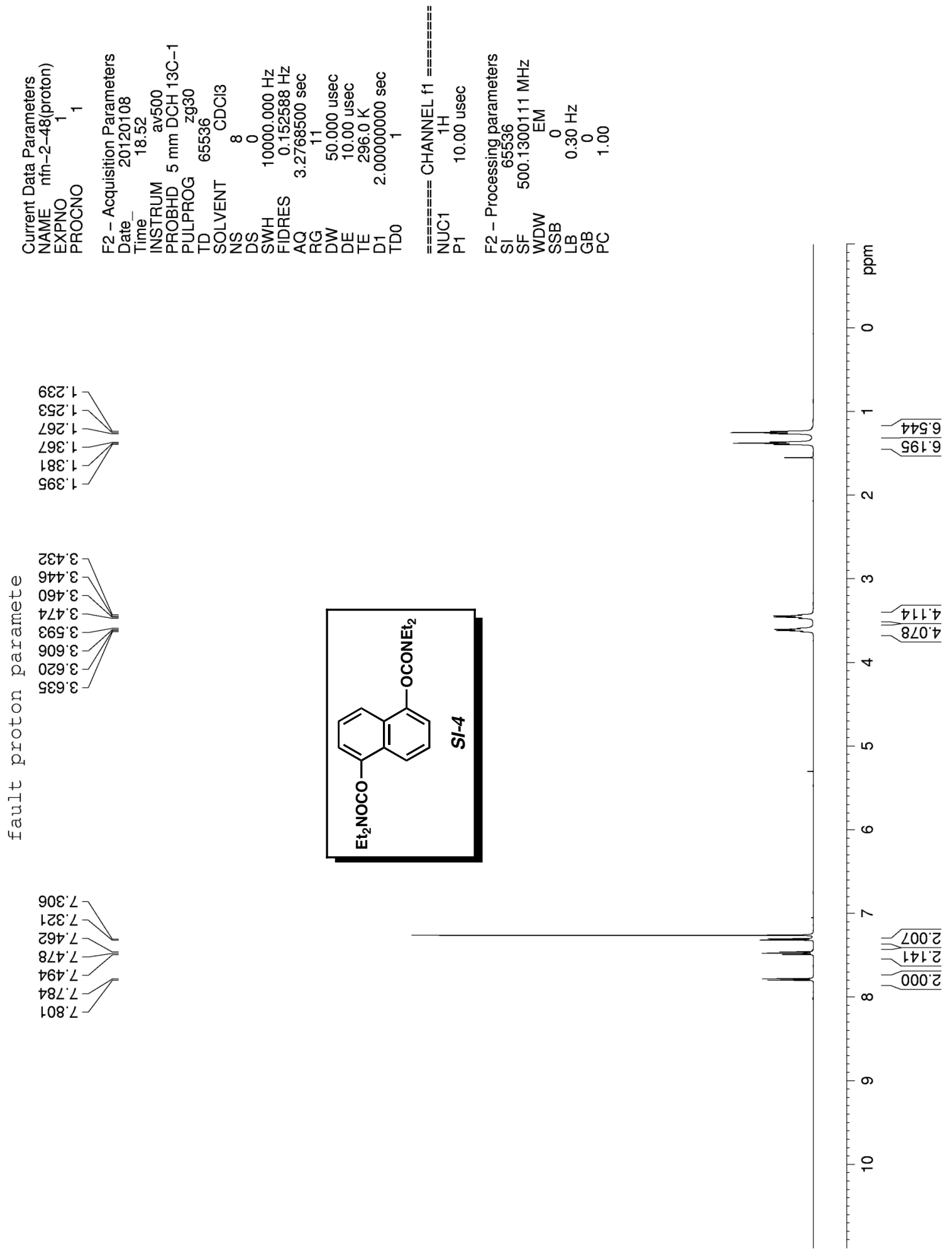

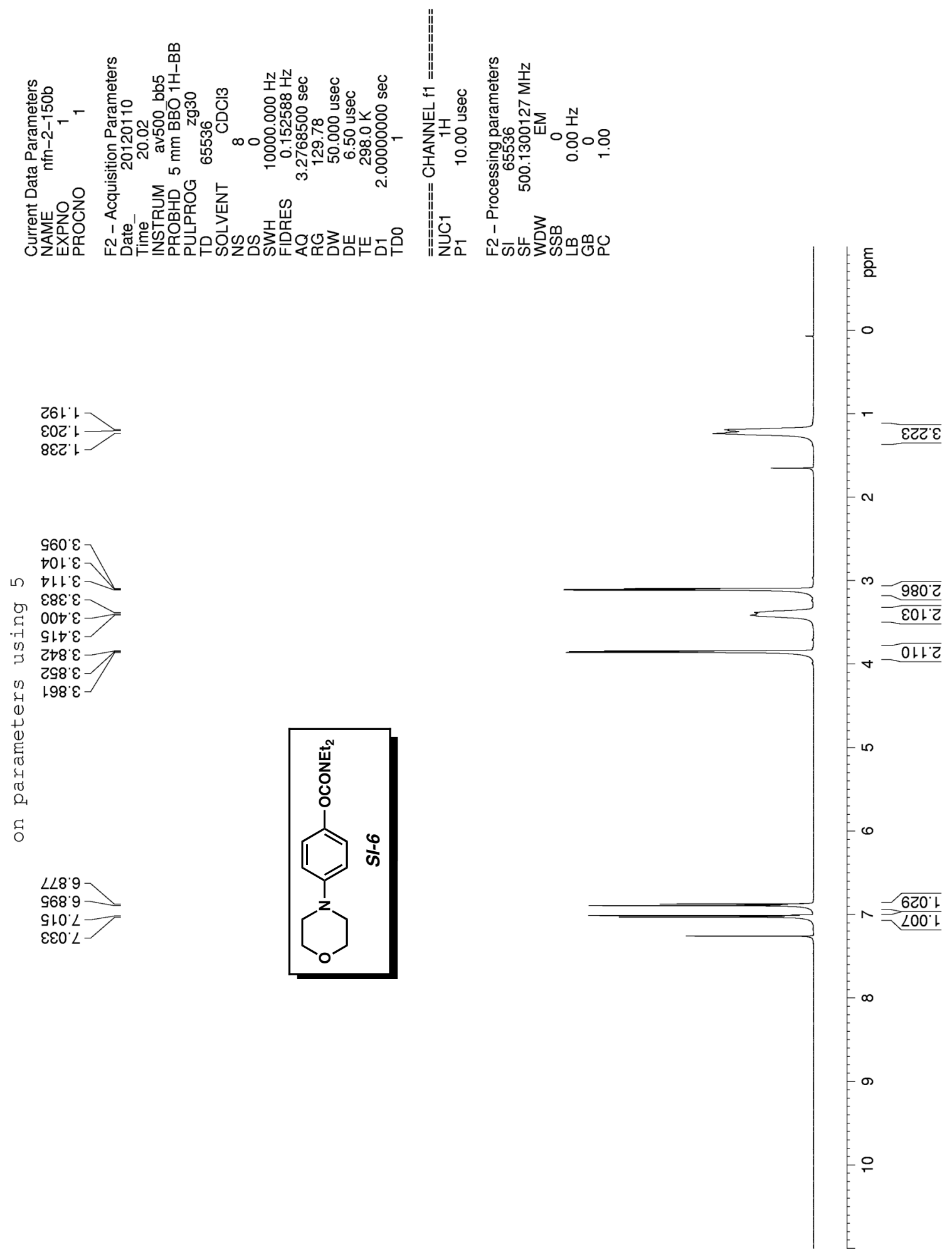

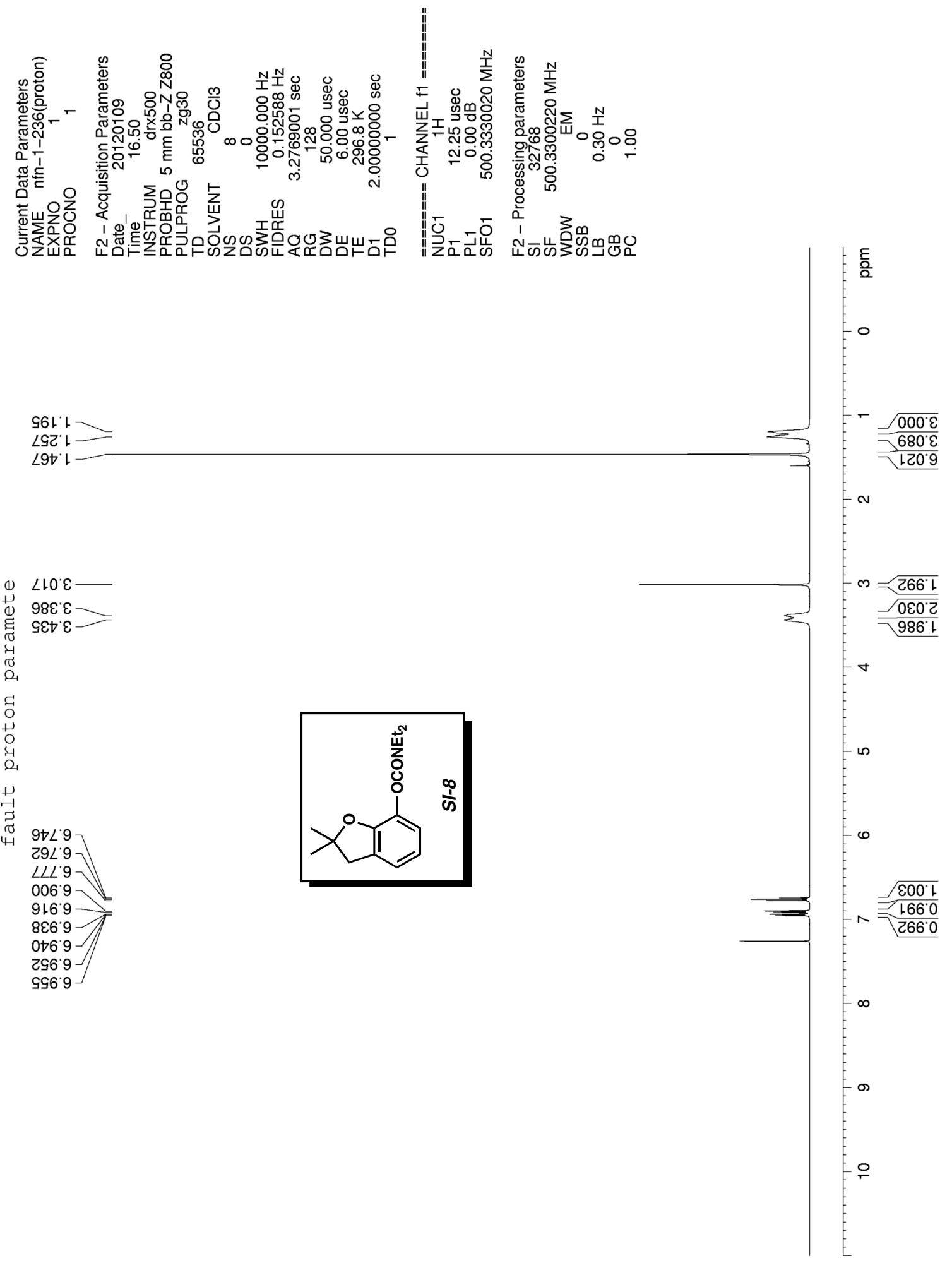

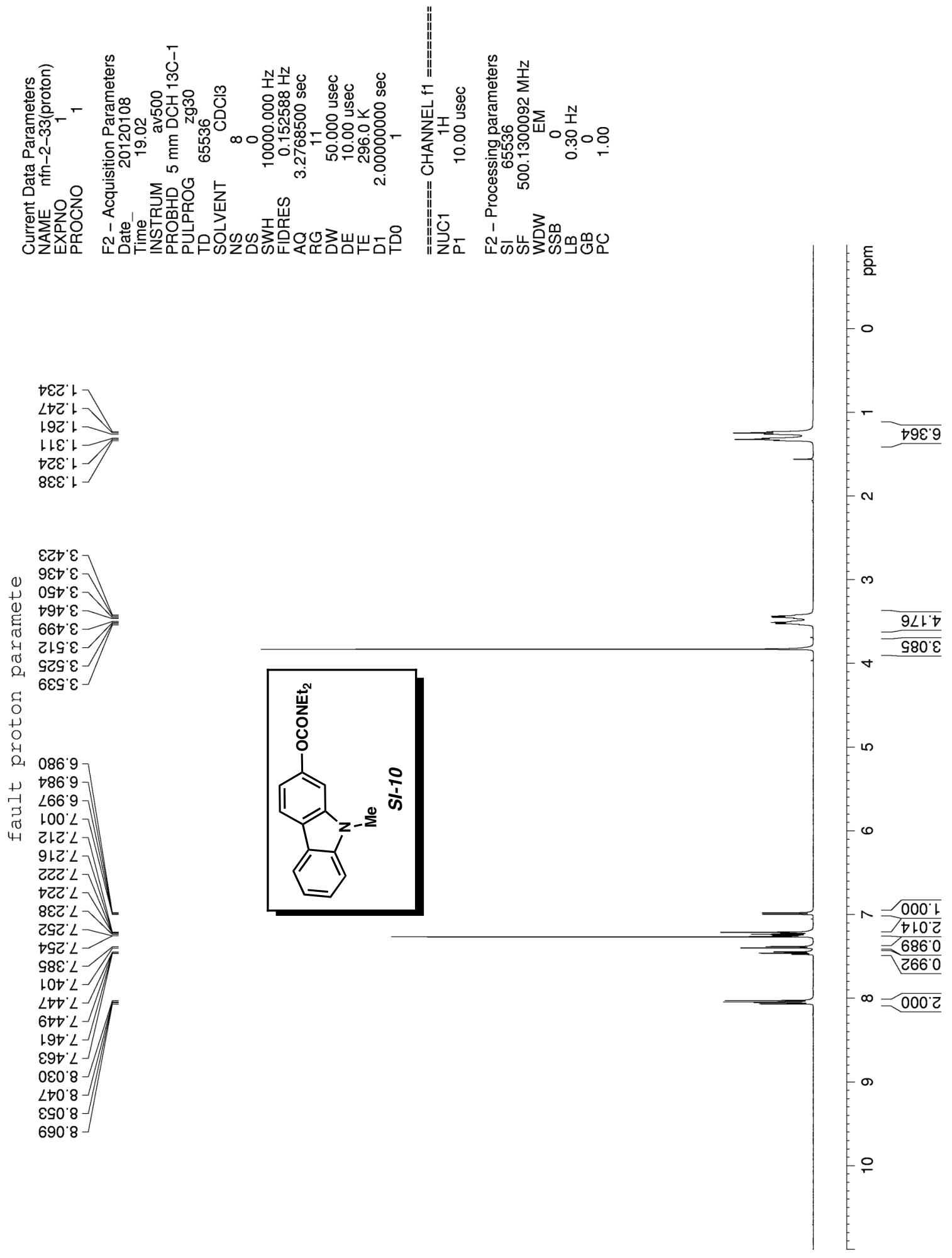

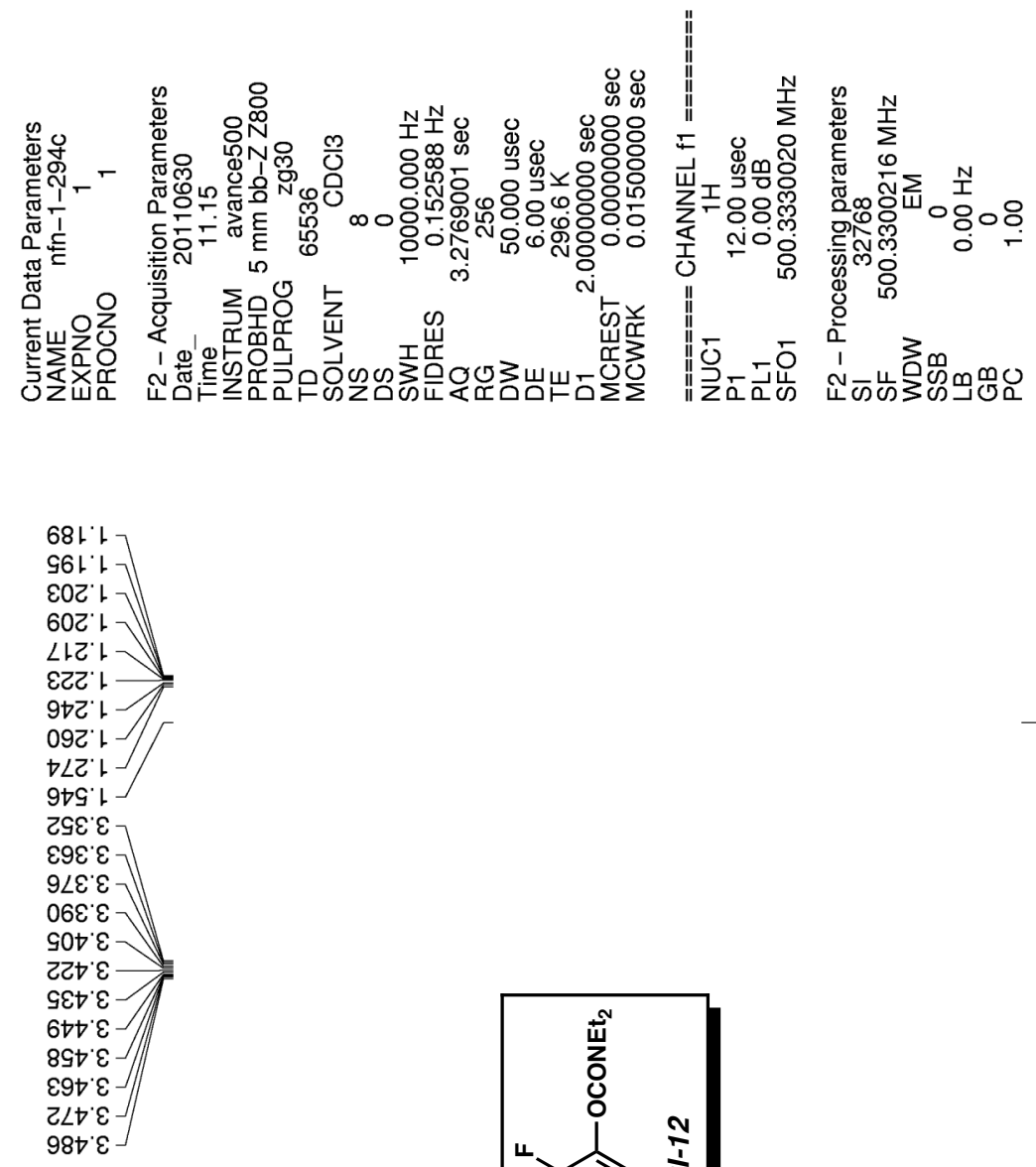

$690^{\circ} \mathrm{L}$

$\left.980^{\circ} L\right]$

201 $L$

OtZ $L$

S๑C'L

092.

$992 \angle$

$662 \angle$

$\varepsilon 0 \varepsilon^{\prime} L$

8เE'L

टटह' $L$
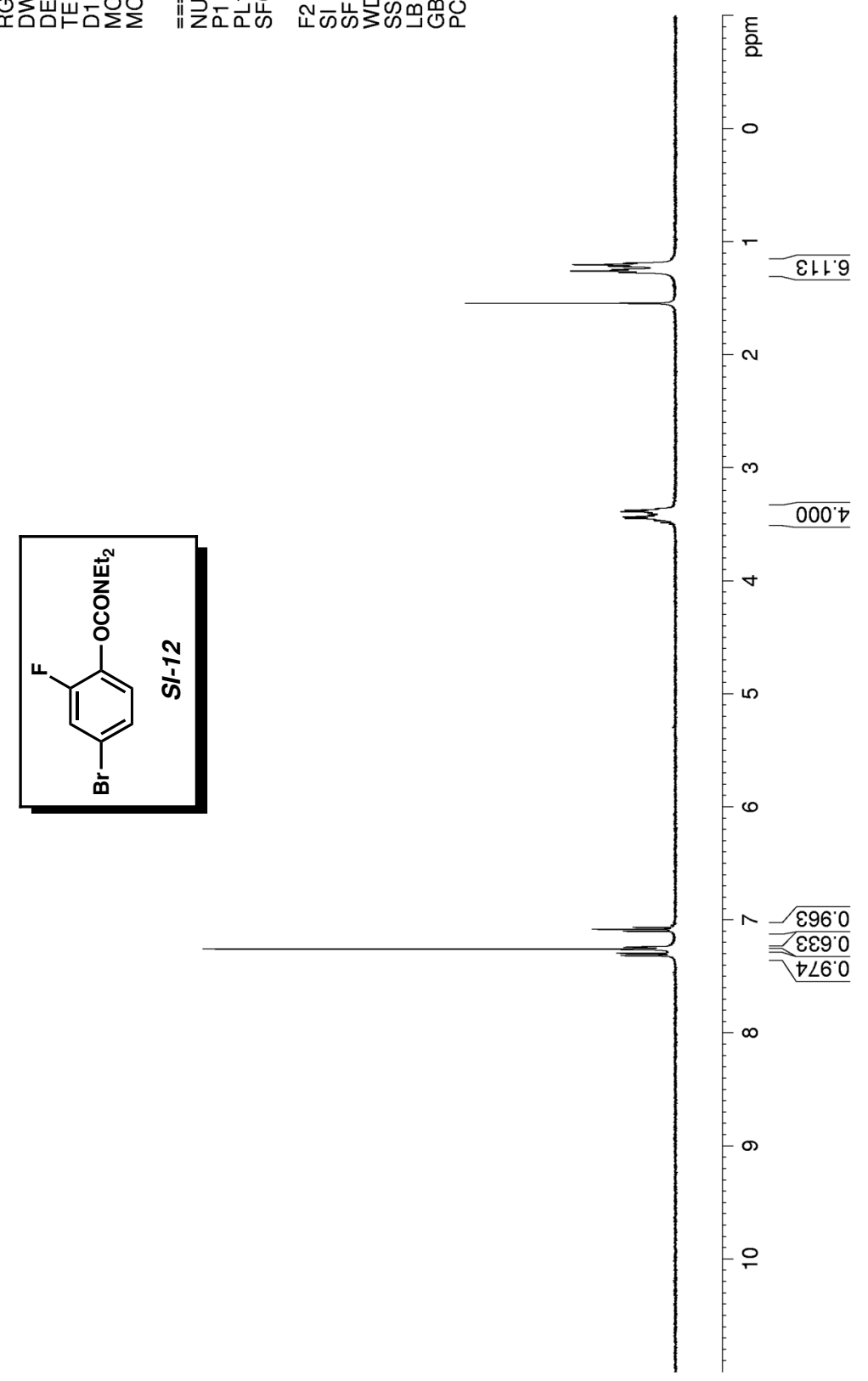

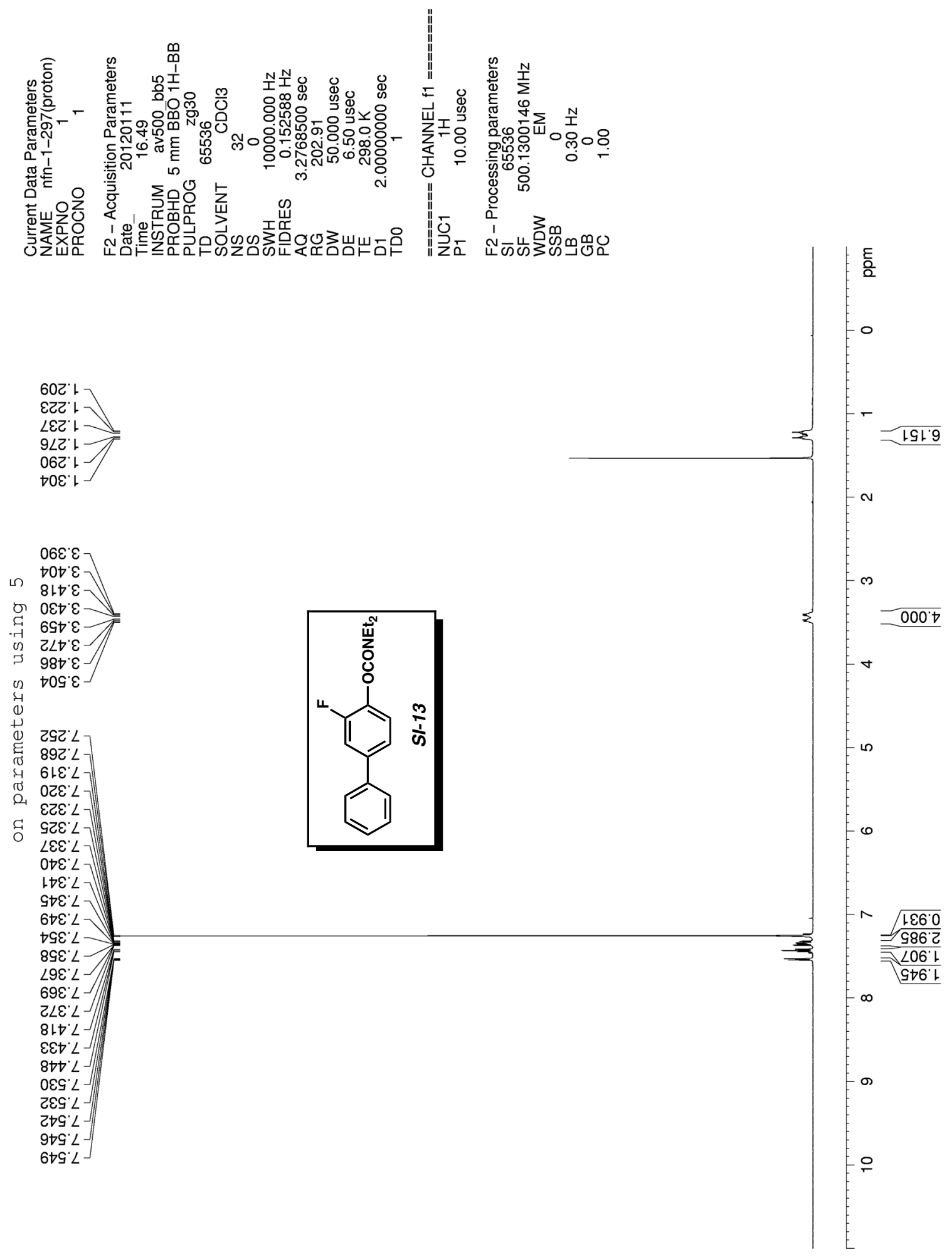

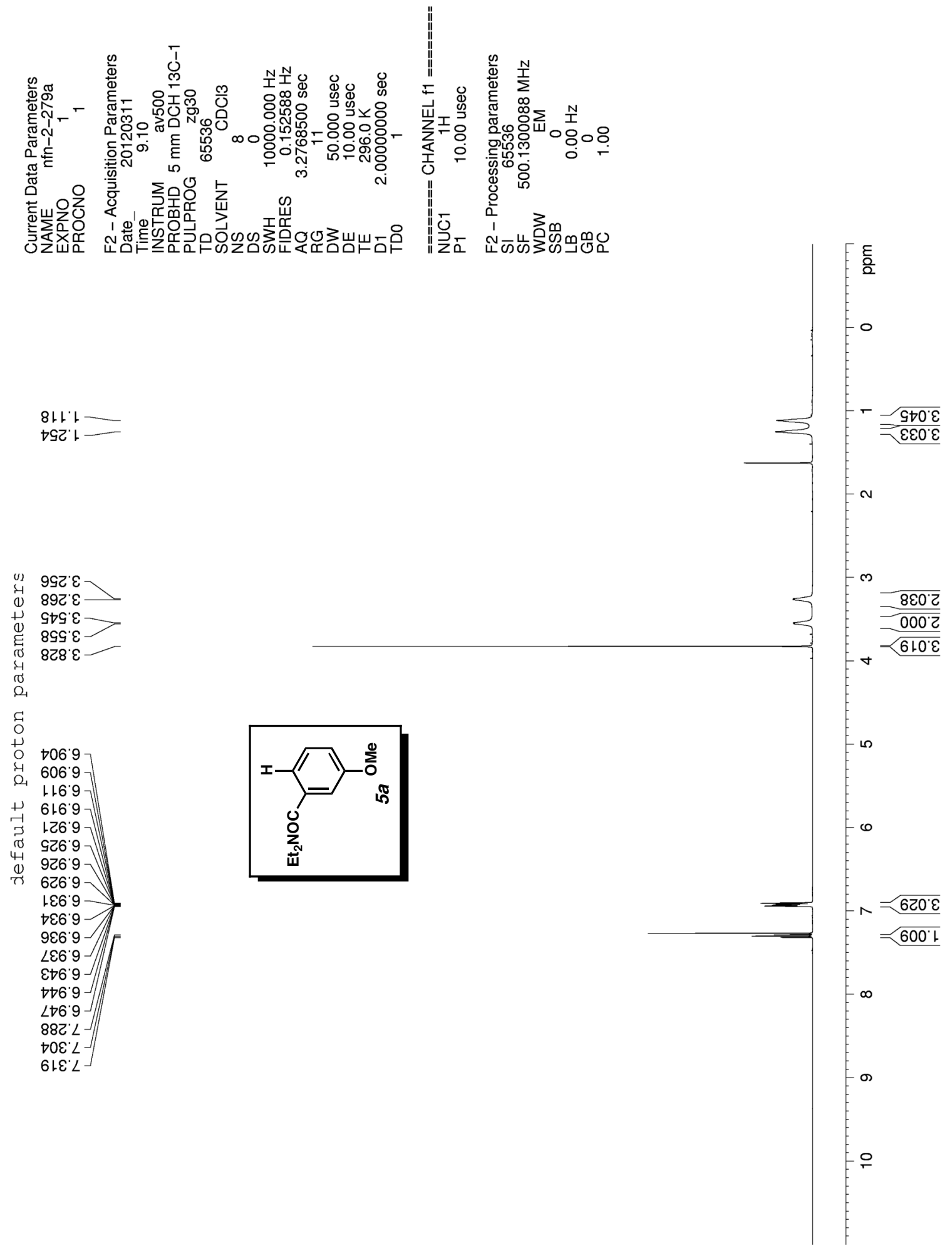

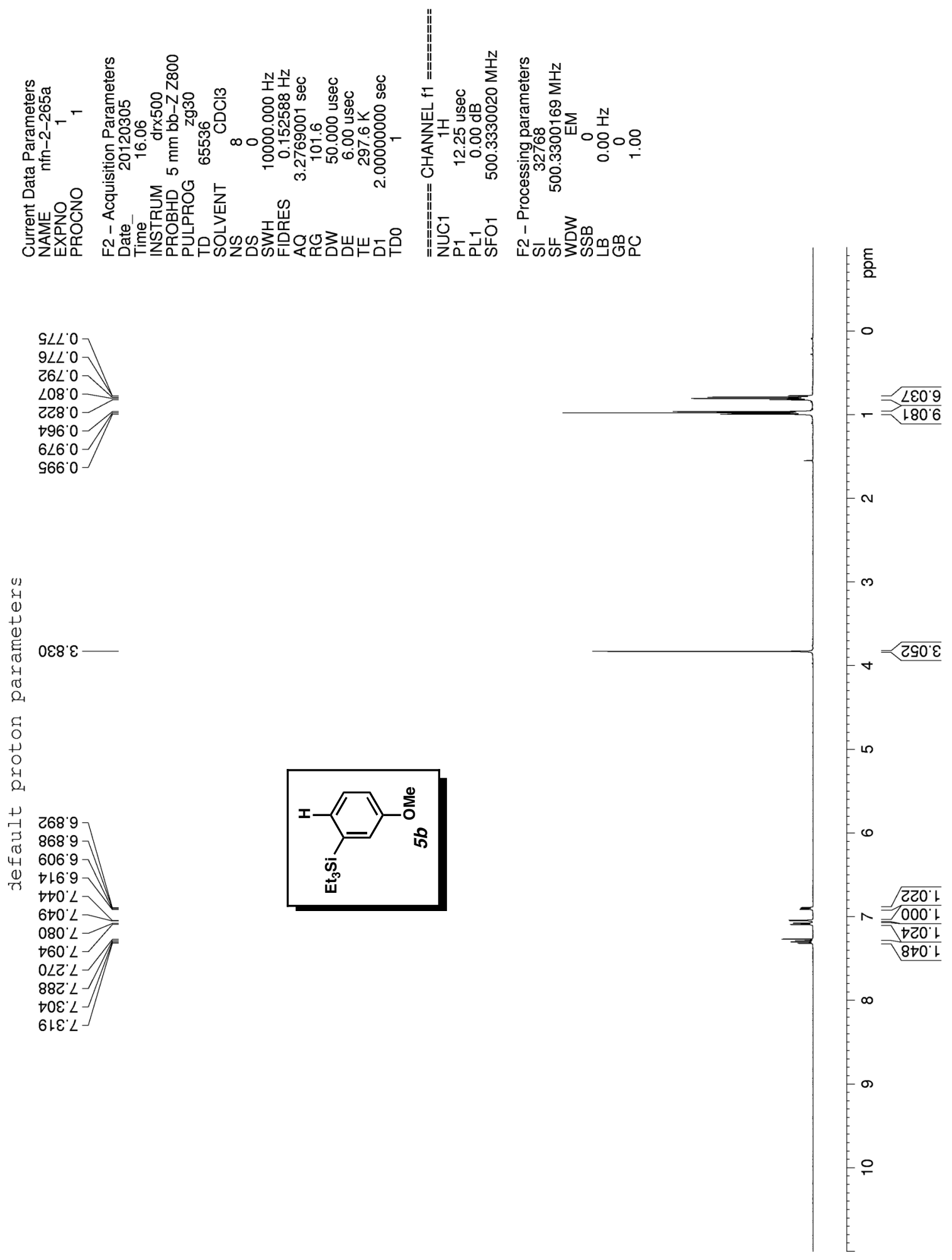

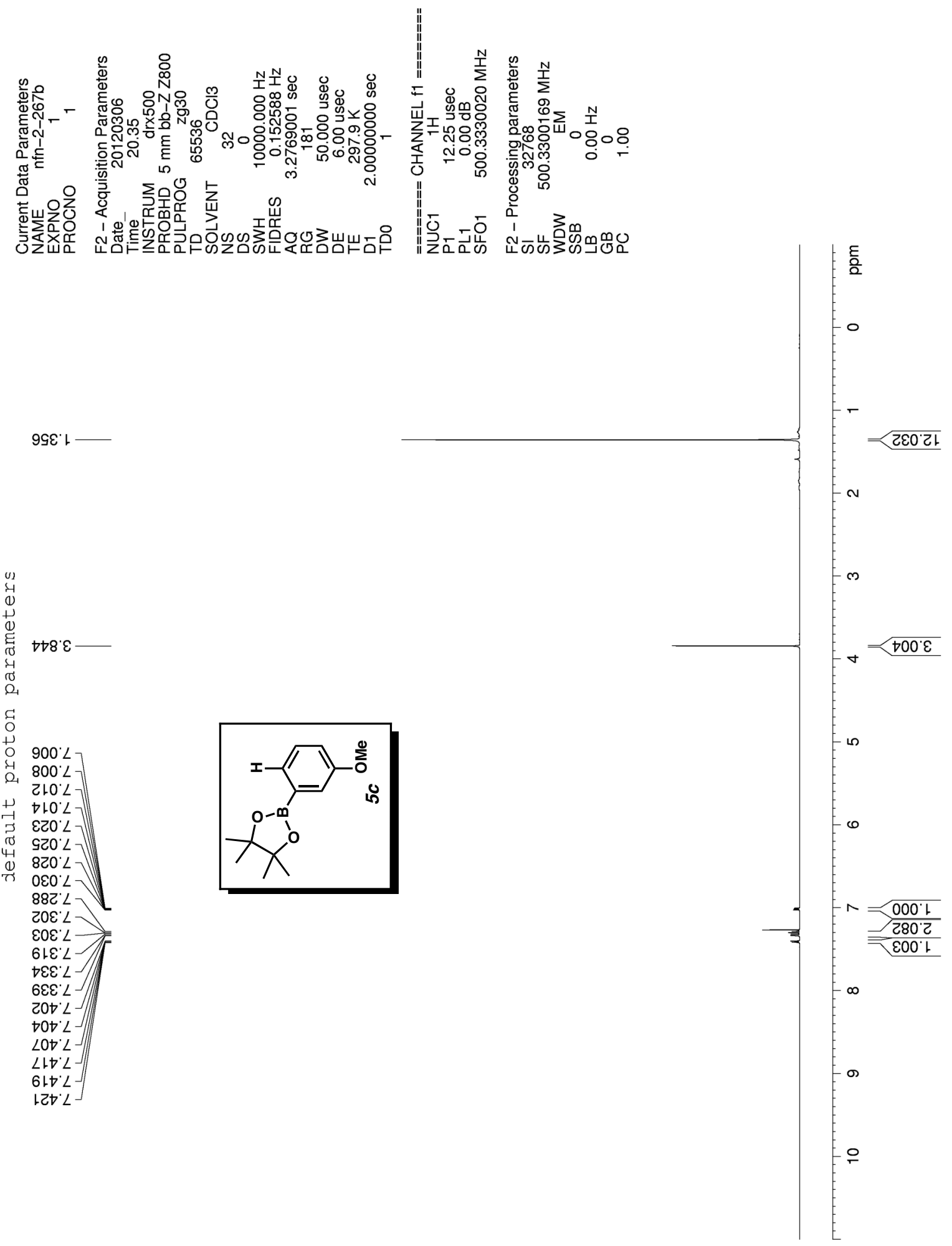

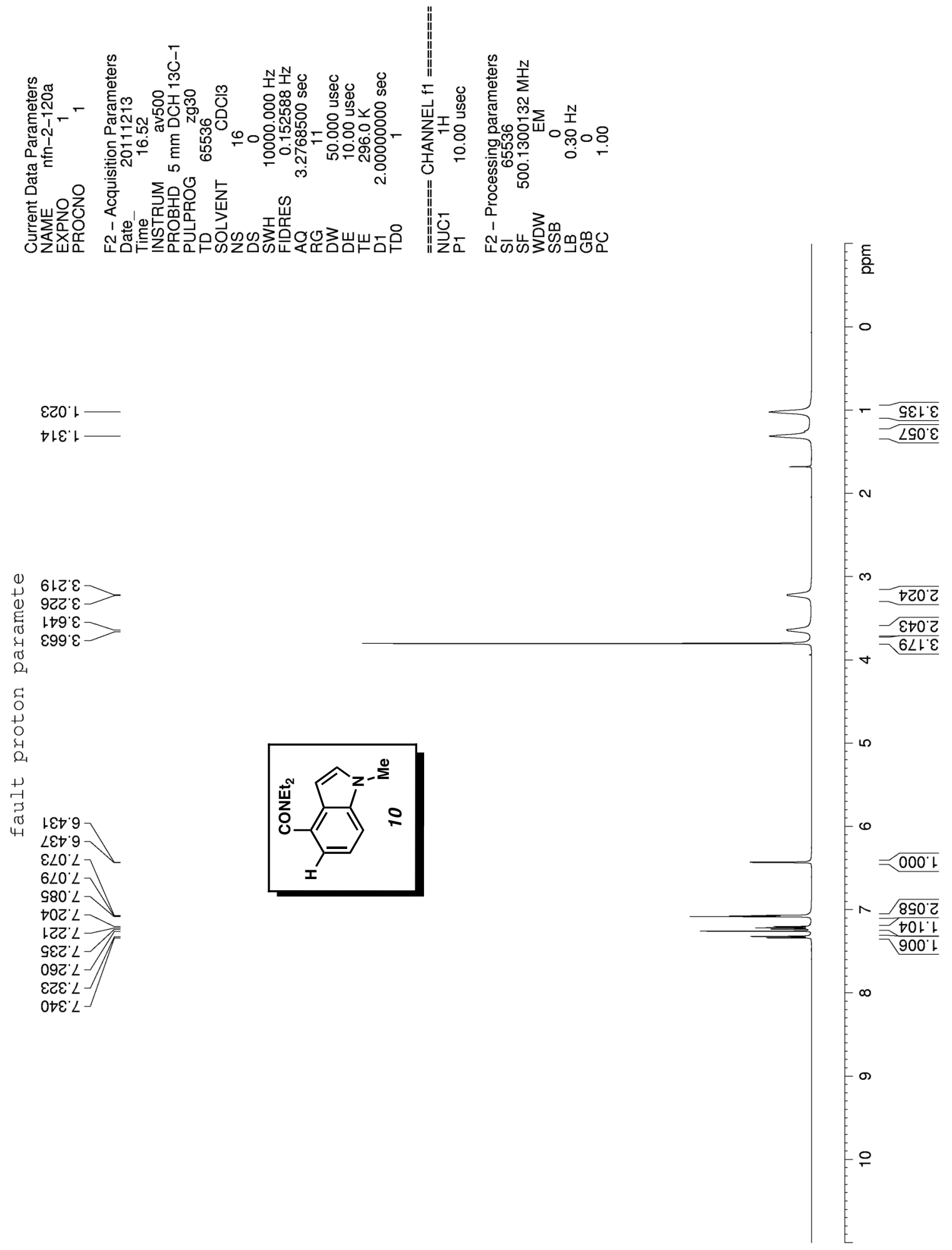

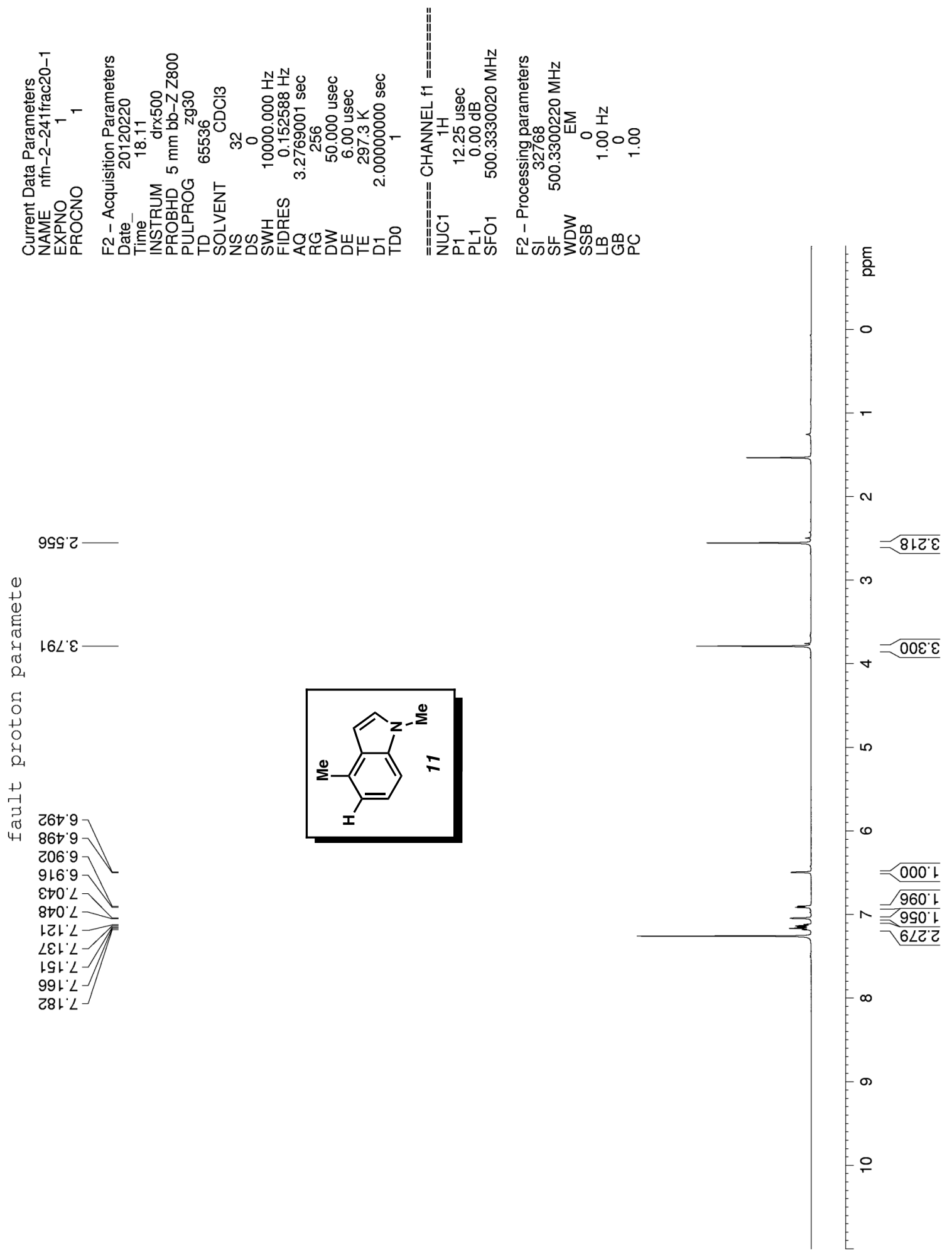

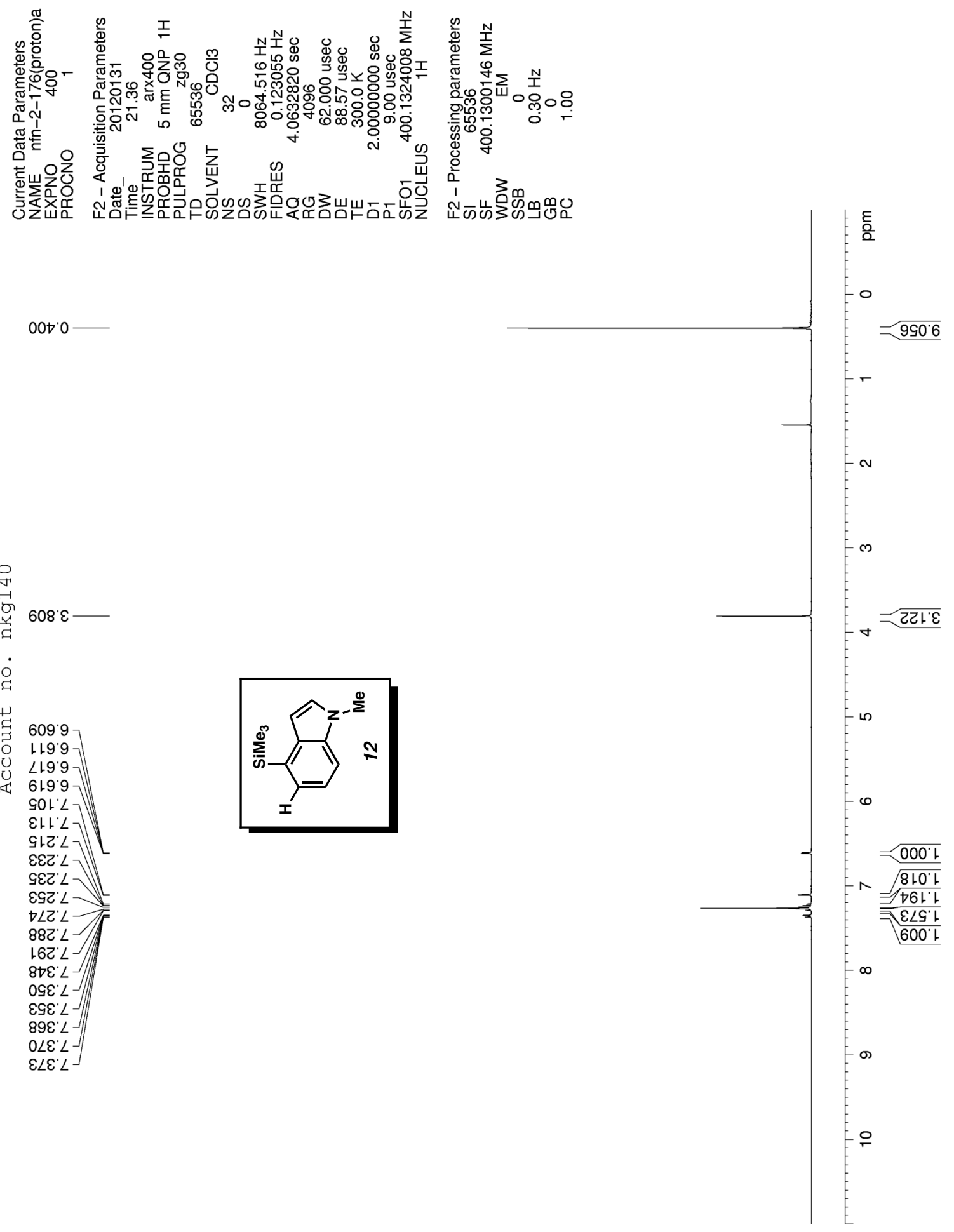

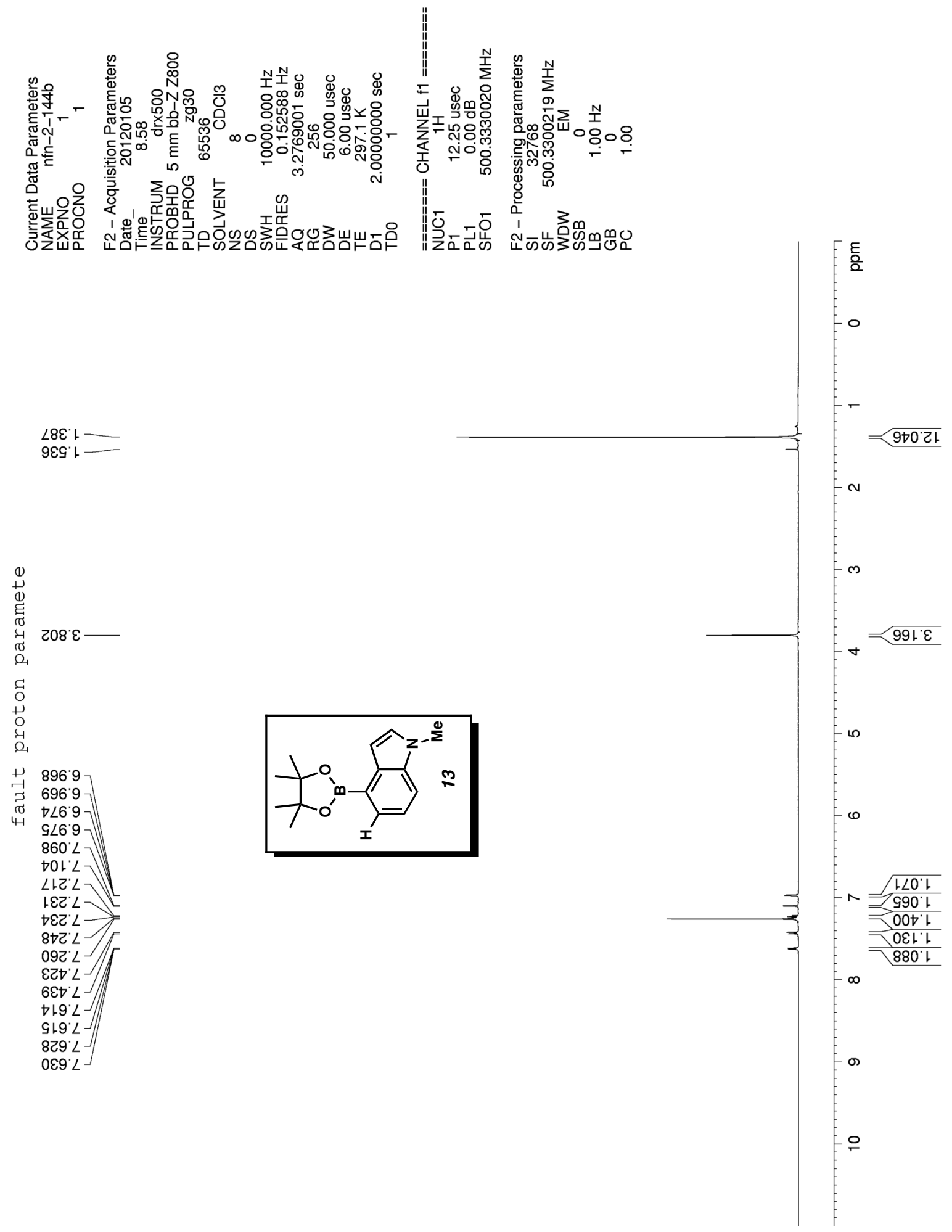


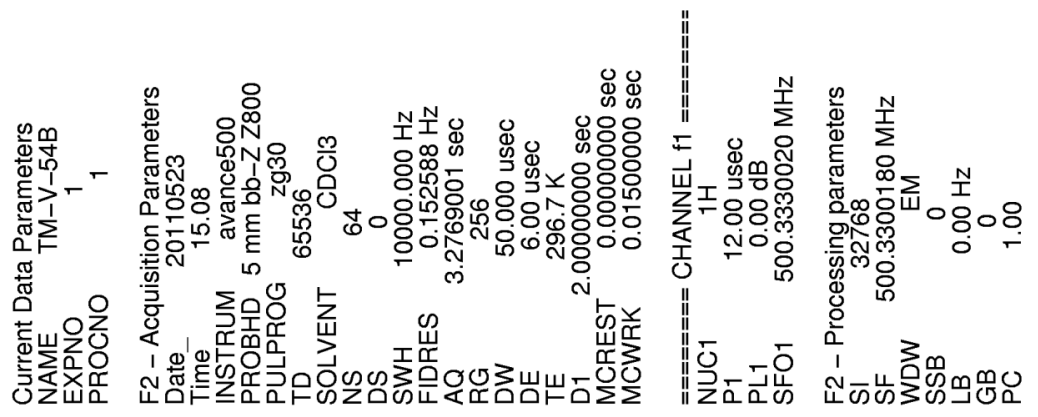

0
+1
0
5
0
0
1
0
0
0
5
0
0
+
0
24
0
0
1
1
5
0
0
4

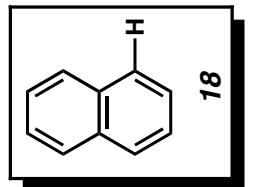

$69 Z^{\circ} \angle$

$987^{\circ} L$

$16 t^{\circ} 1$

$\angle 6 \nabla^{\circ} \angle$

$\rightarrow 092$

เ98 $\angle$

898 L

5982

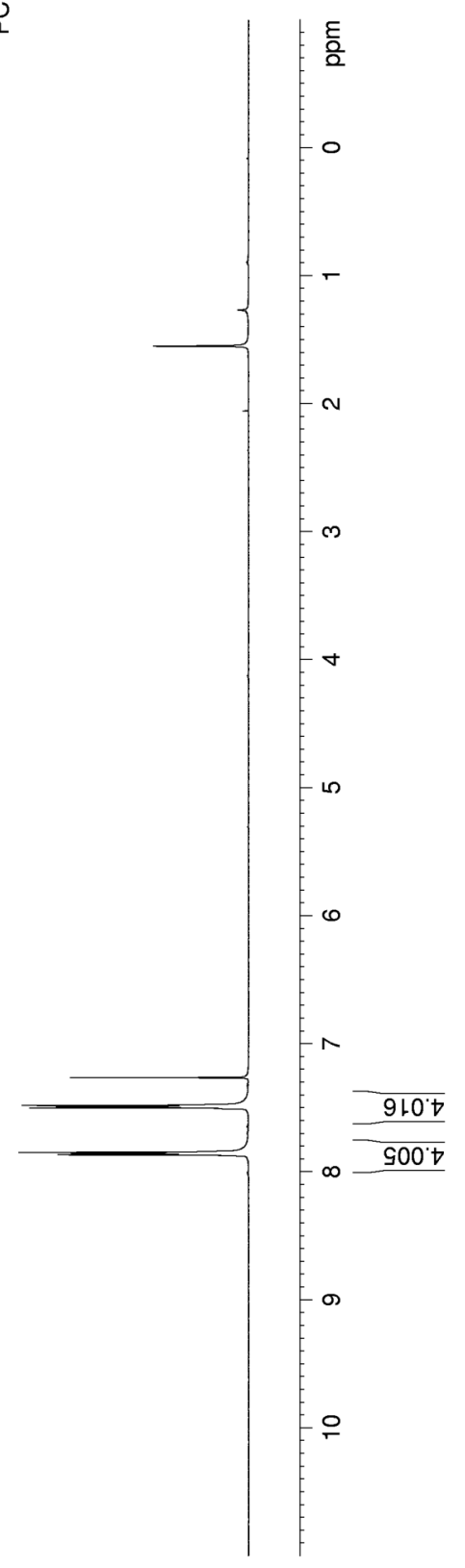



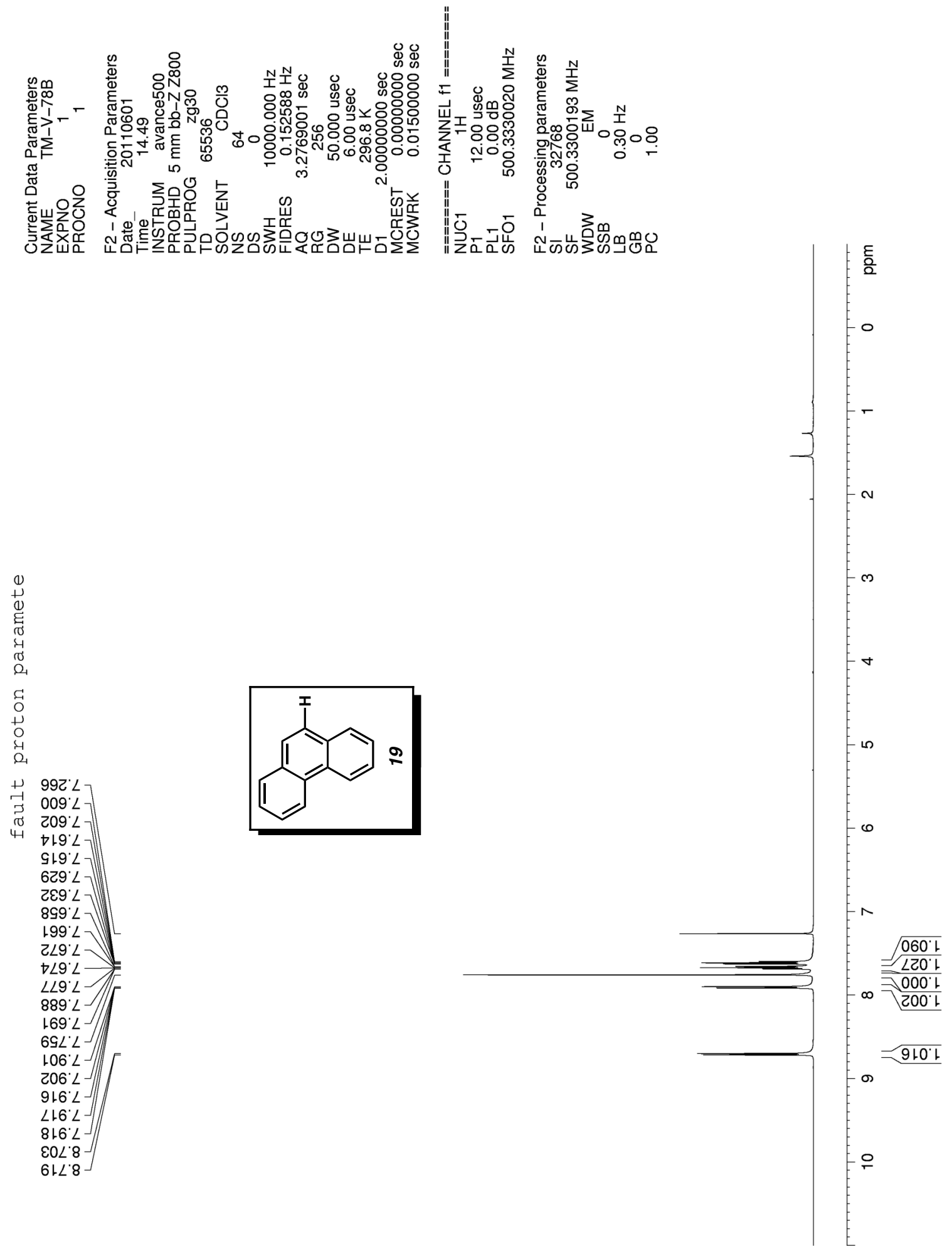

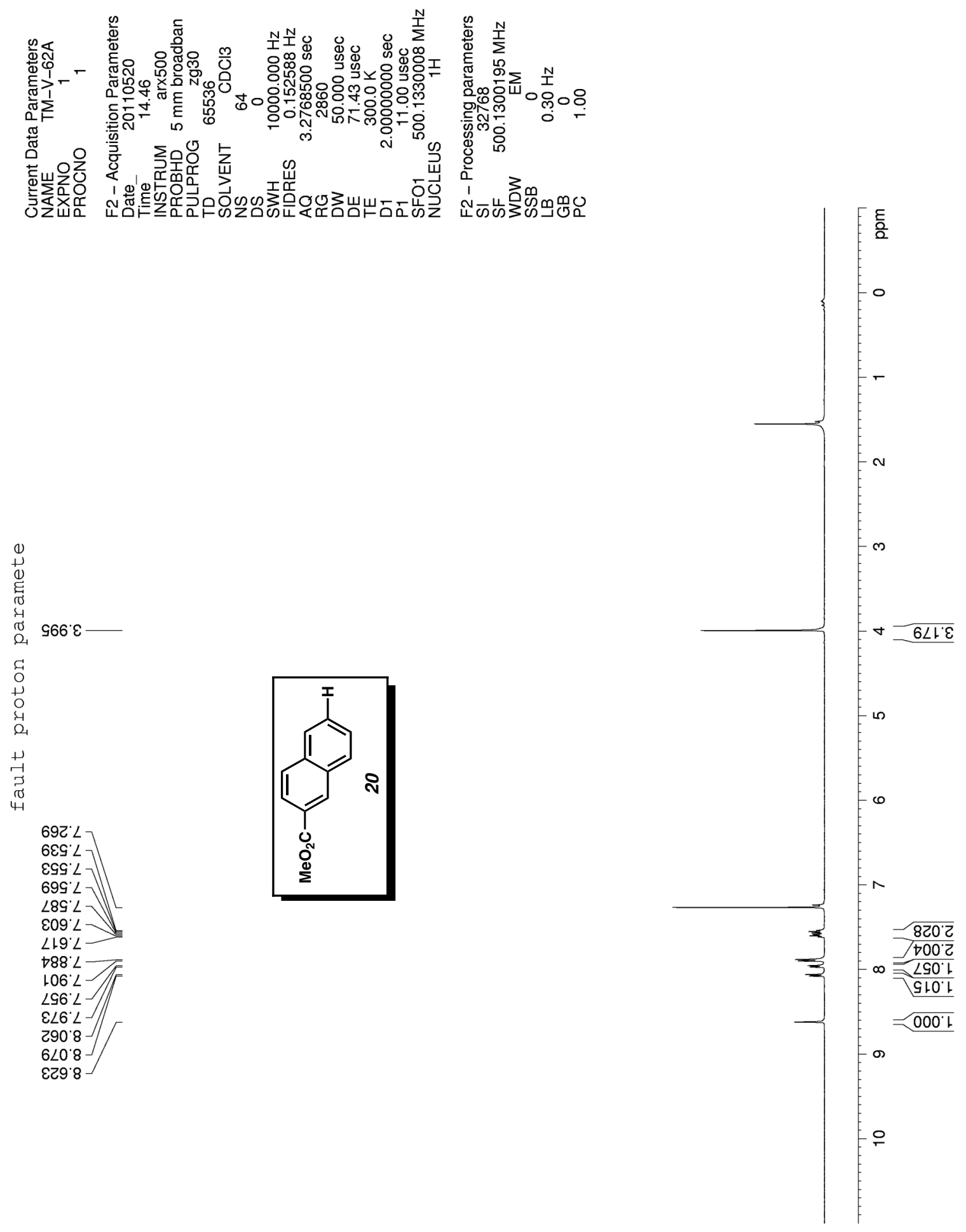

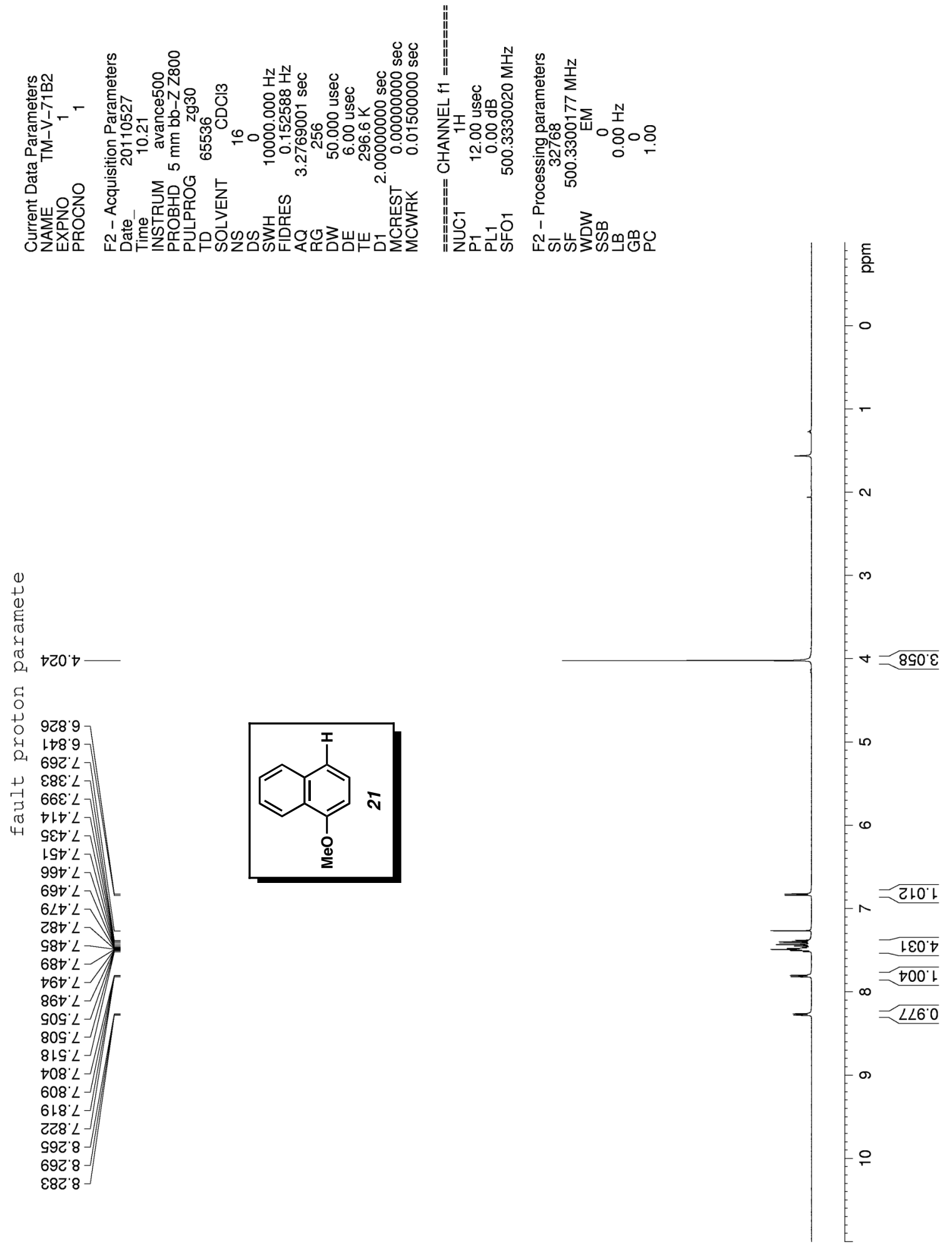

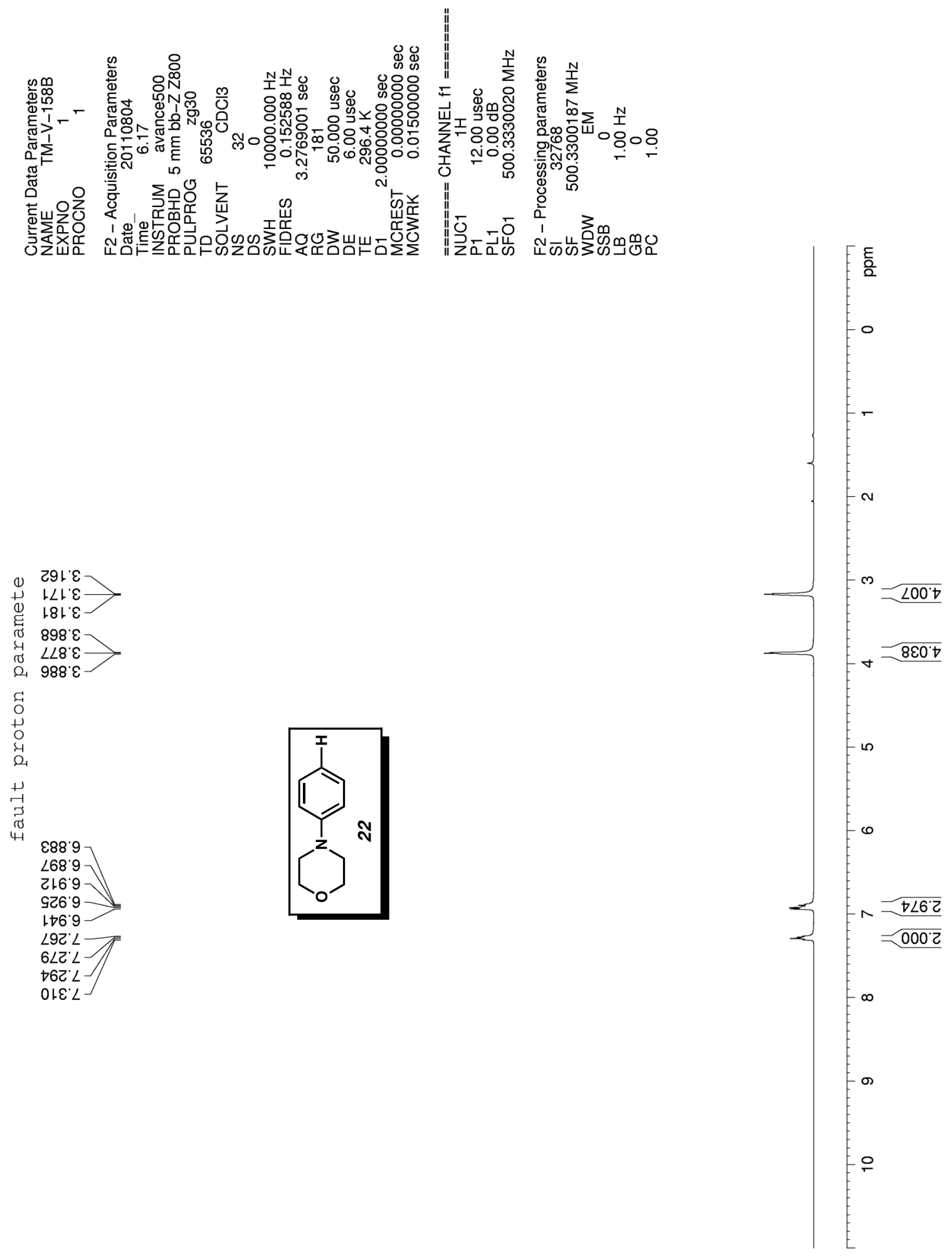


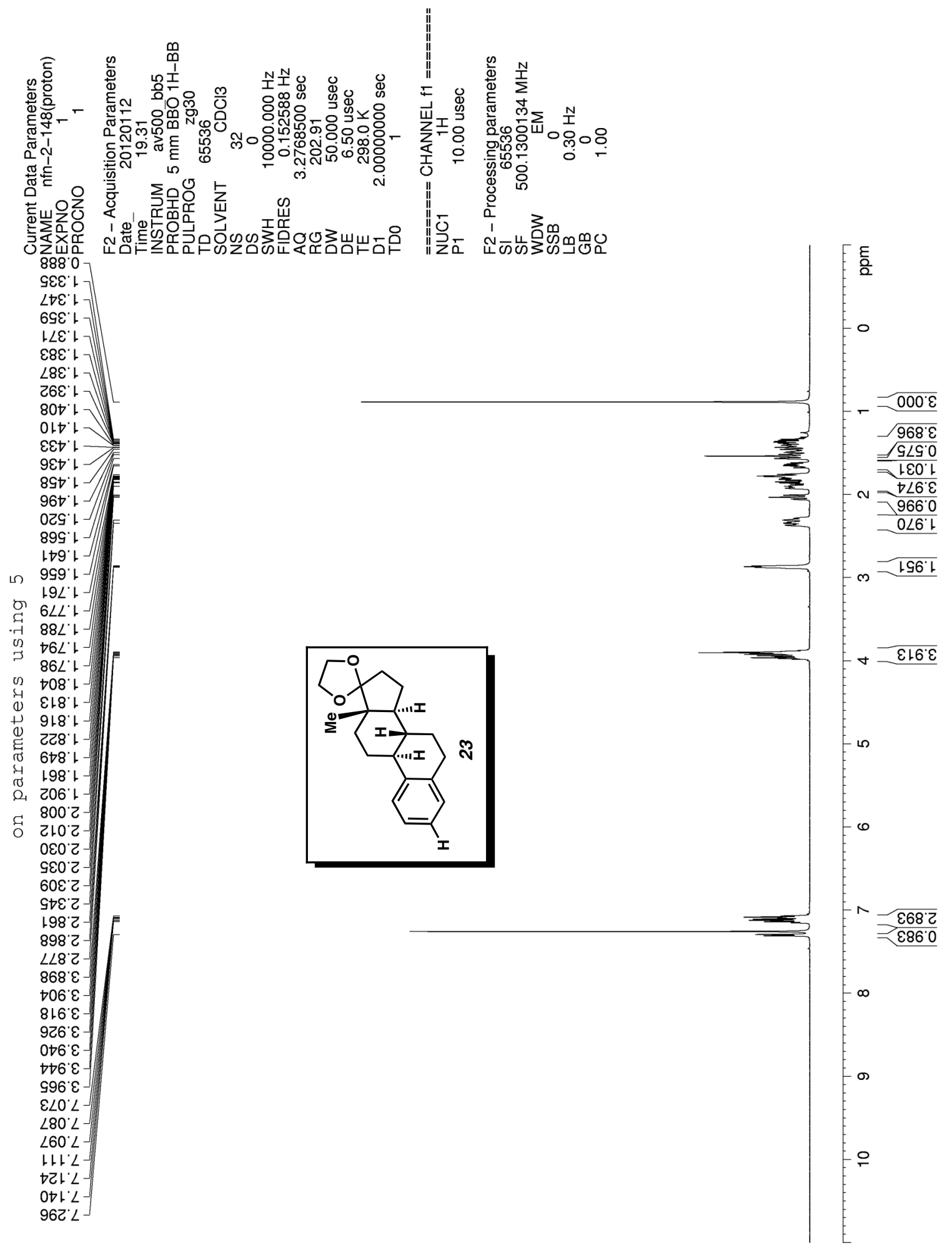



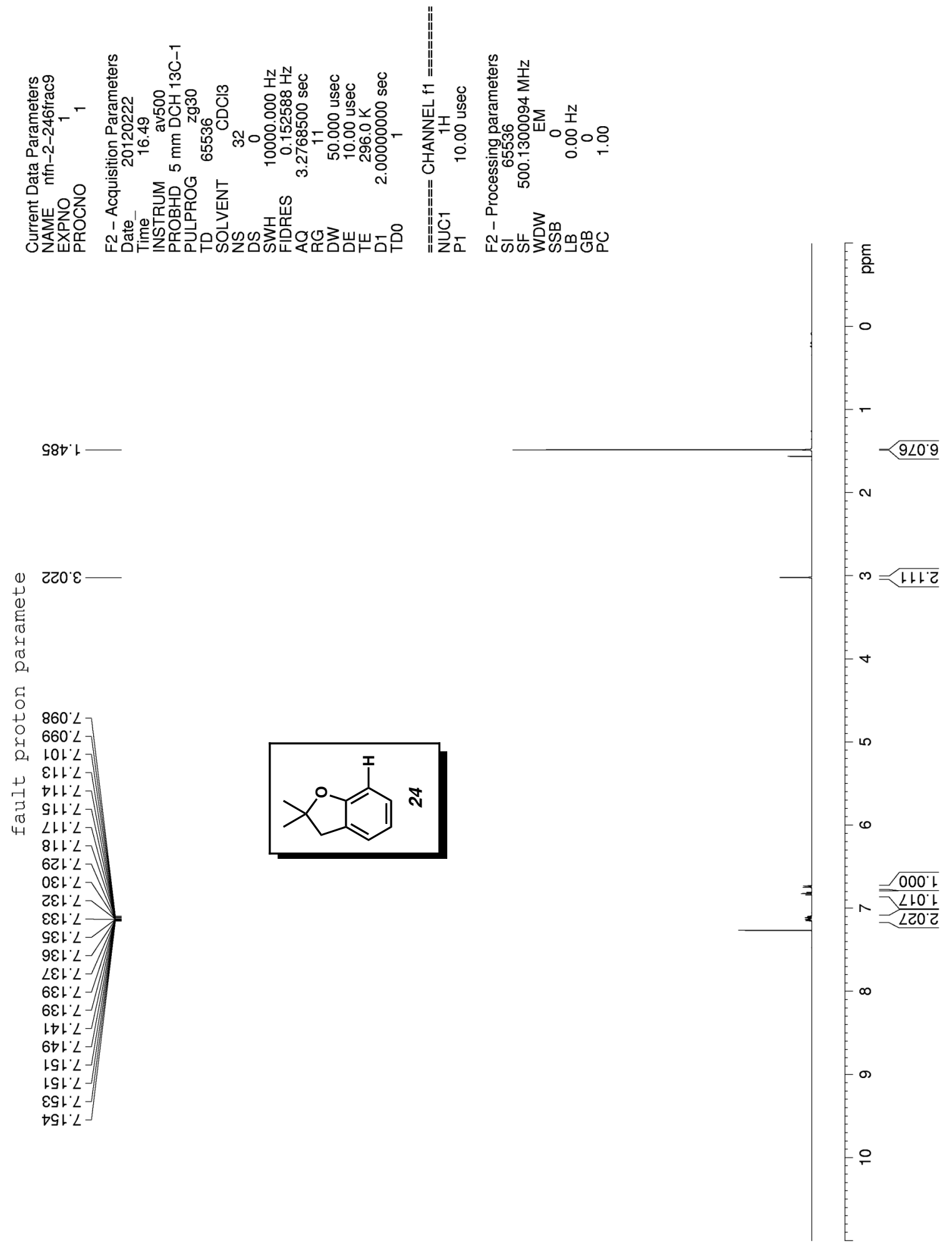

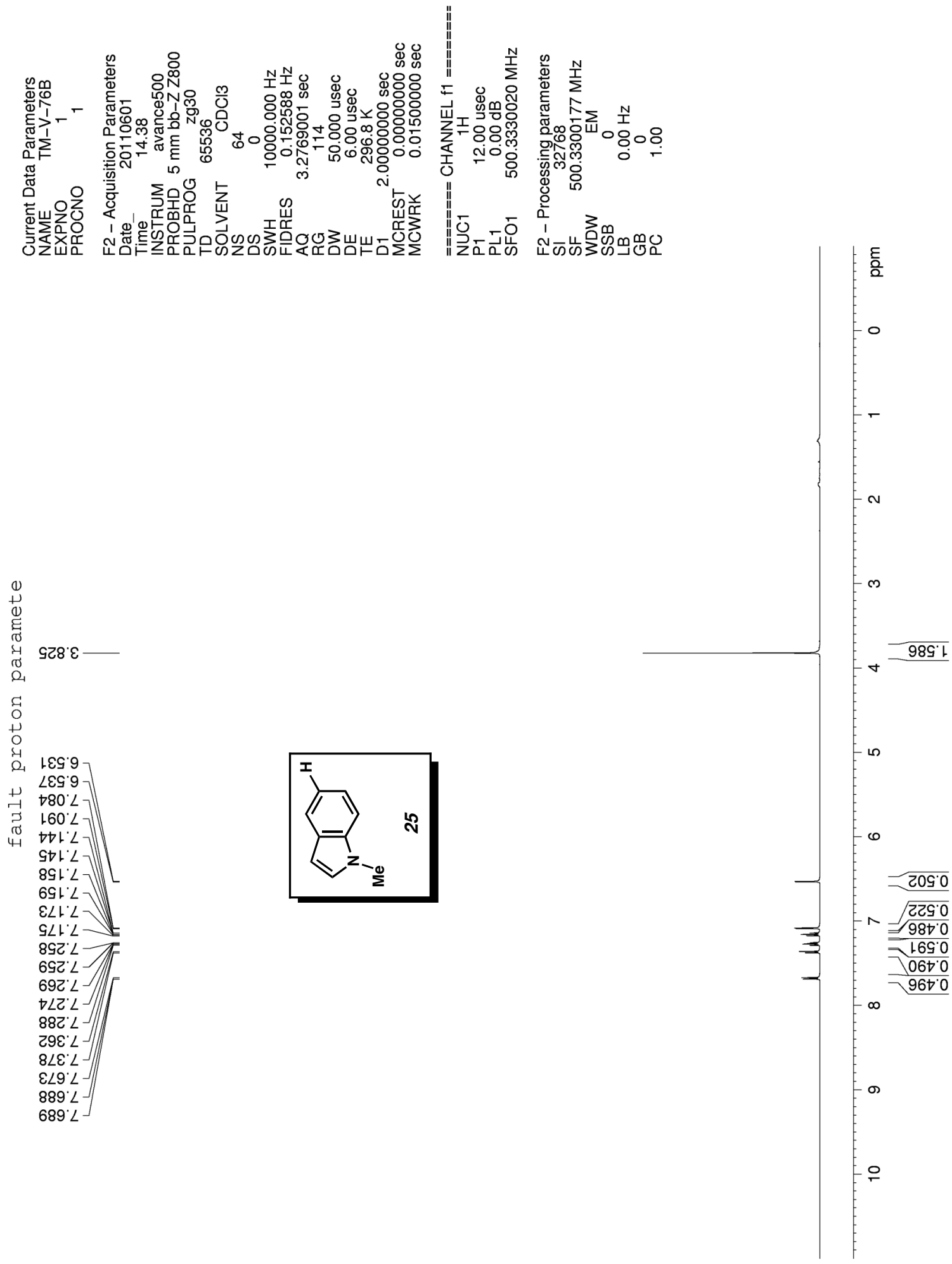

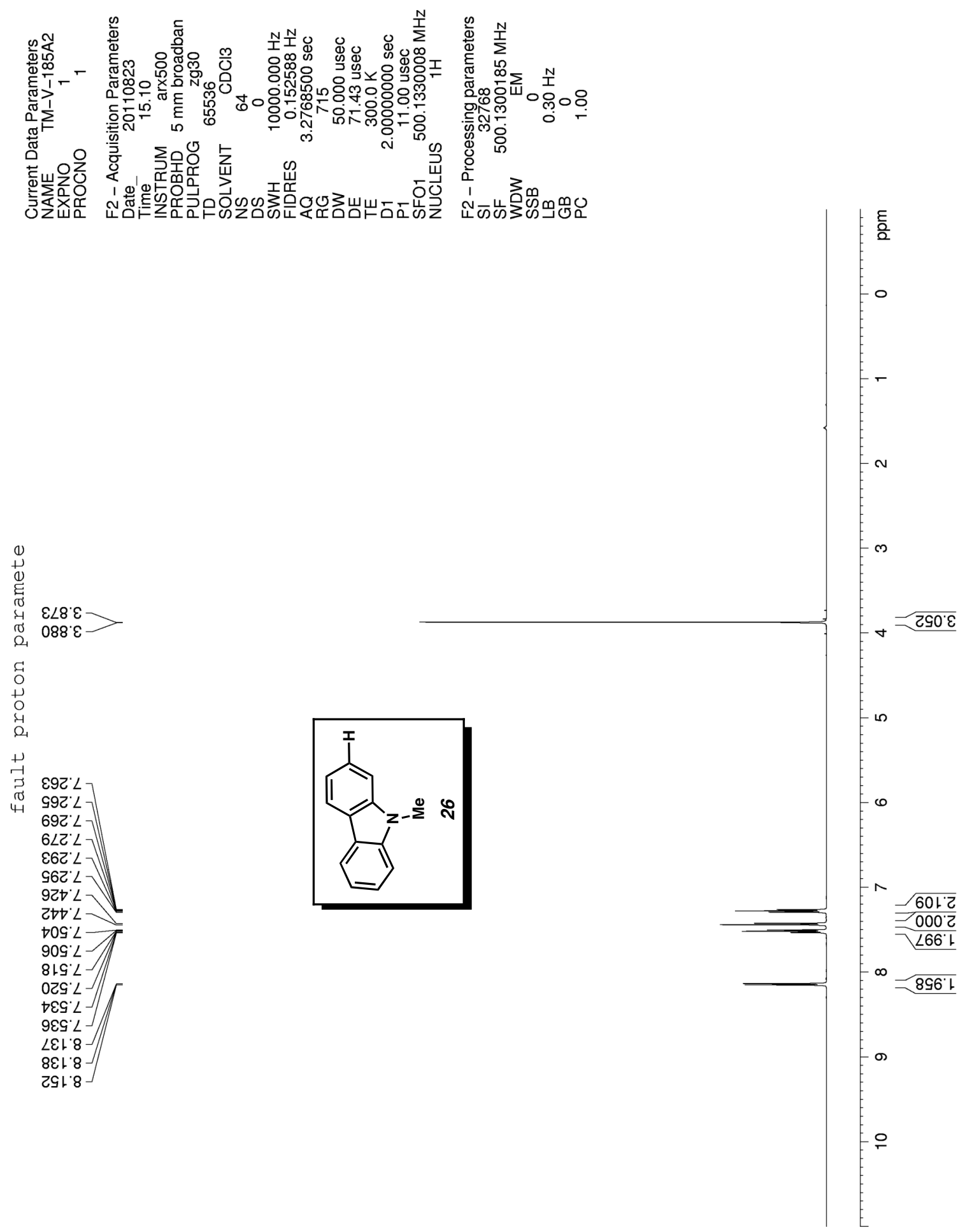


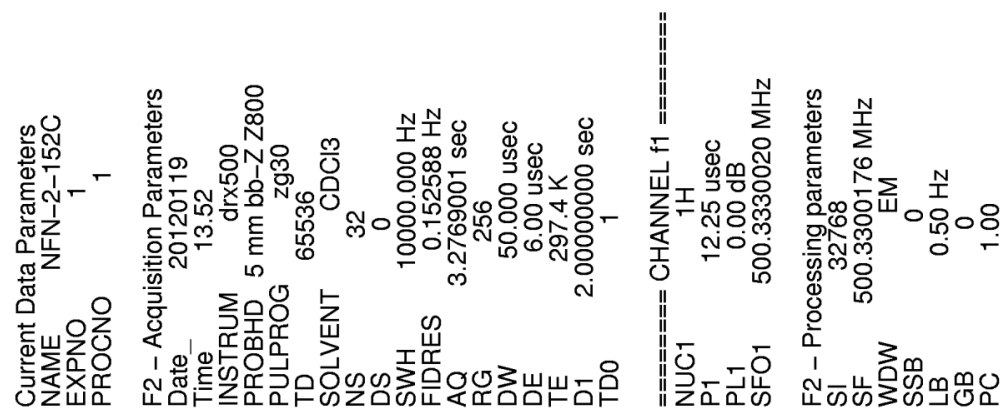

0
+1
0
0
0
0
1
0
0
0
5
0
+
0
0
0
0
1
1
1
5
0
0
4

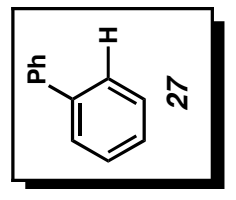

$692^{\prime} \angle$

$\varepsilon t \varepsilon \cdot L$

$89 \varepsilon^{\circ} L$

$8 \varepsilon \nabla^{\circ} L$

tSt: $\angle-7$

$89 \nabla^{\circ} \angle$

$919<$

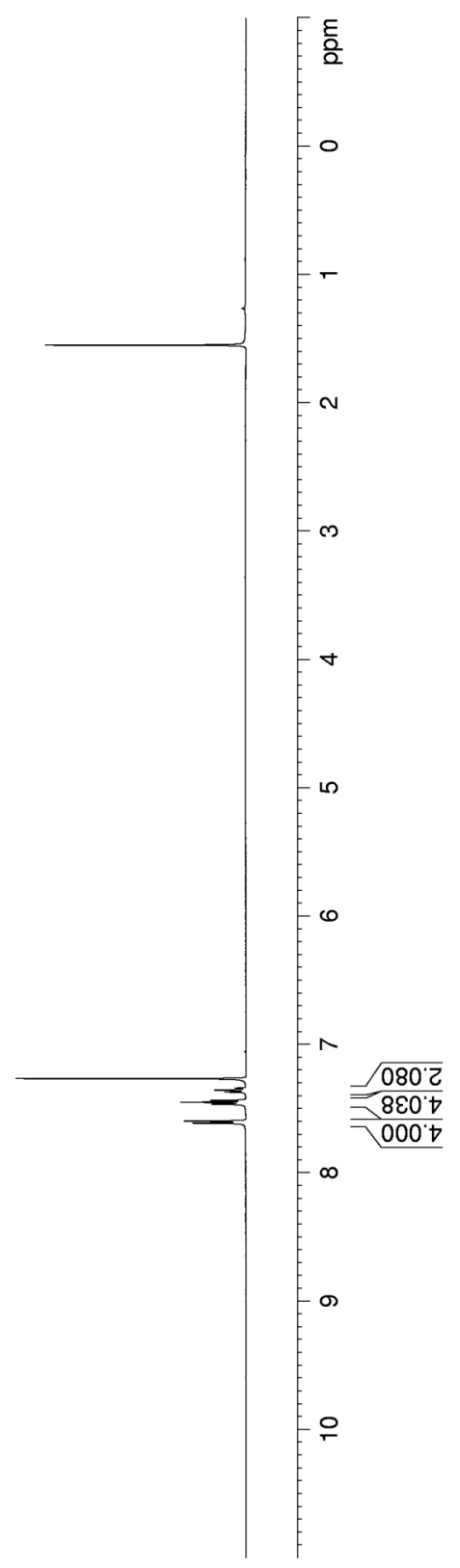



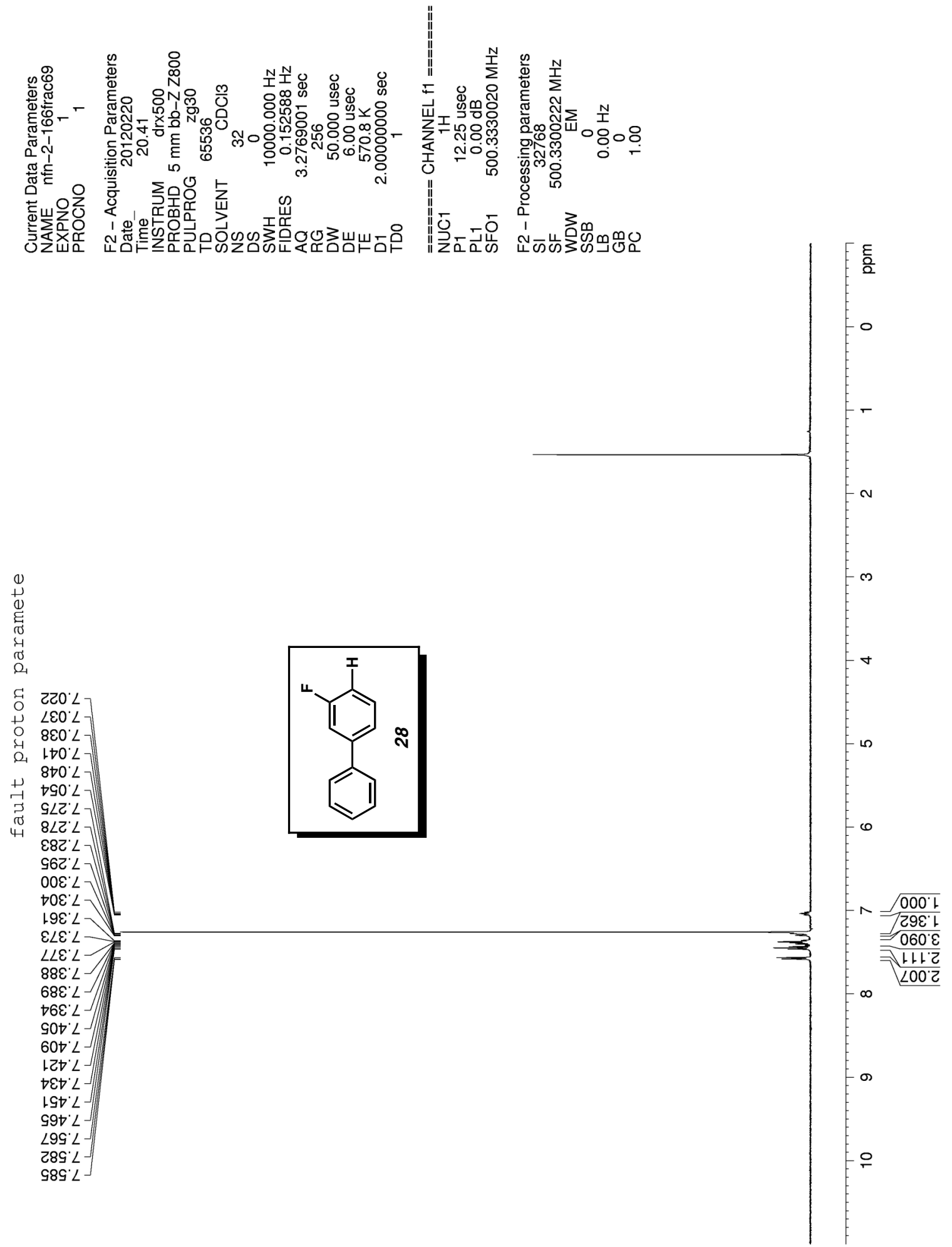


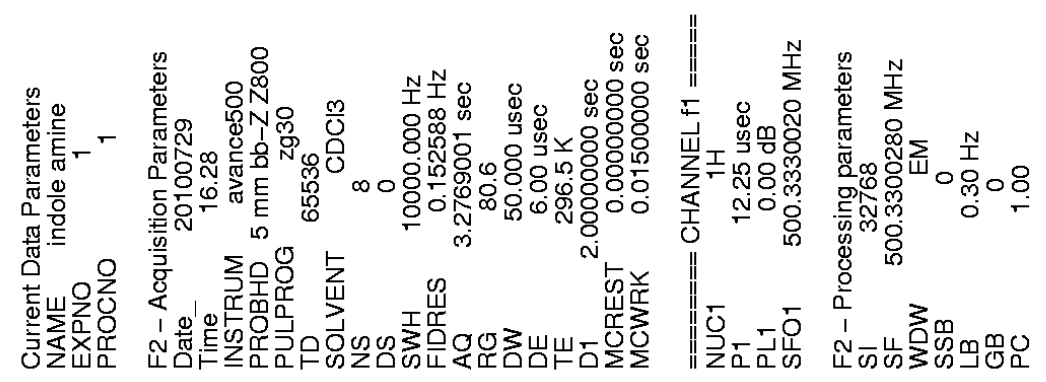

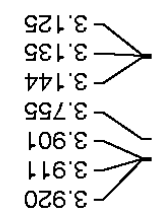

tot' 9

$017 \cdot 9$

$\angle 86^{\circ} 9$

266.97

$900 \circ$

$600 \%$

G.0 2

$\angle G+L-$

$29+\angle 1$

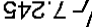

$292 \div$

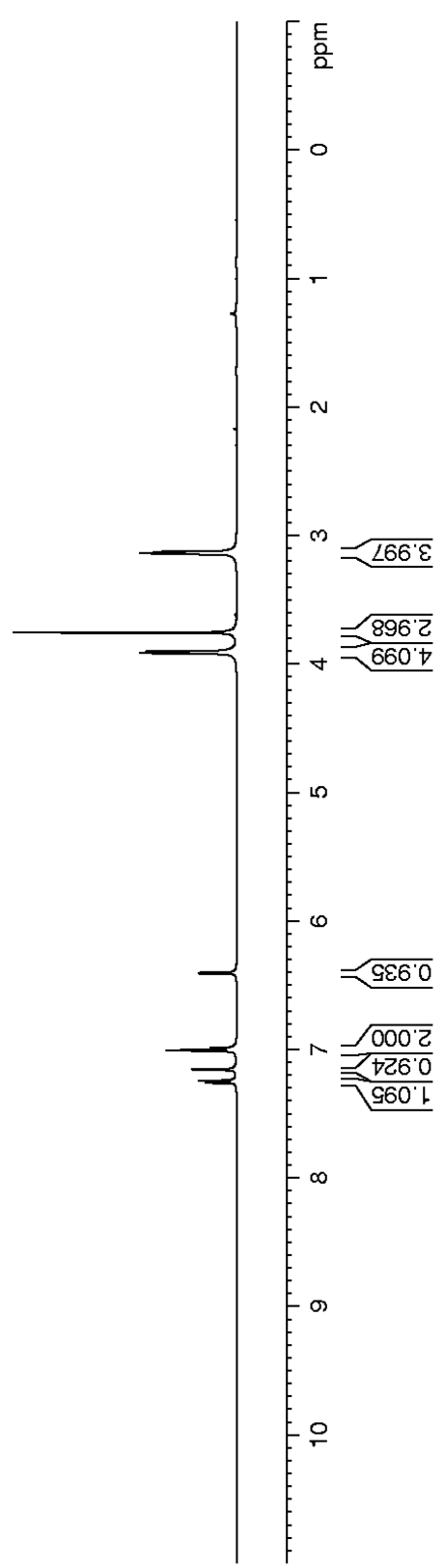



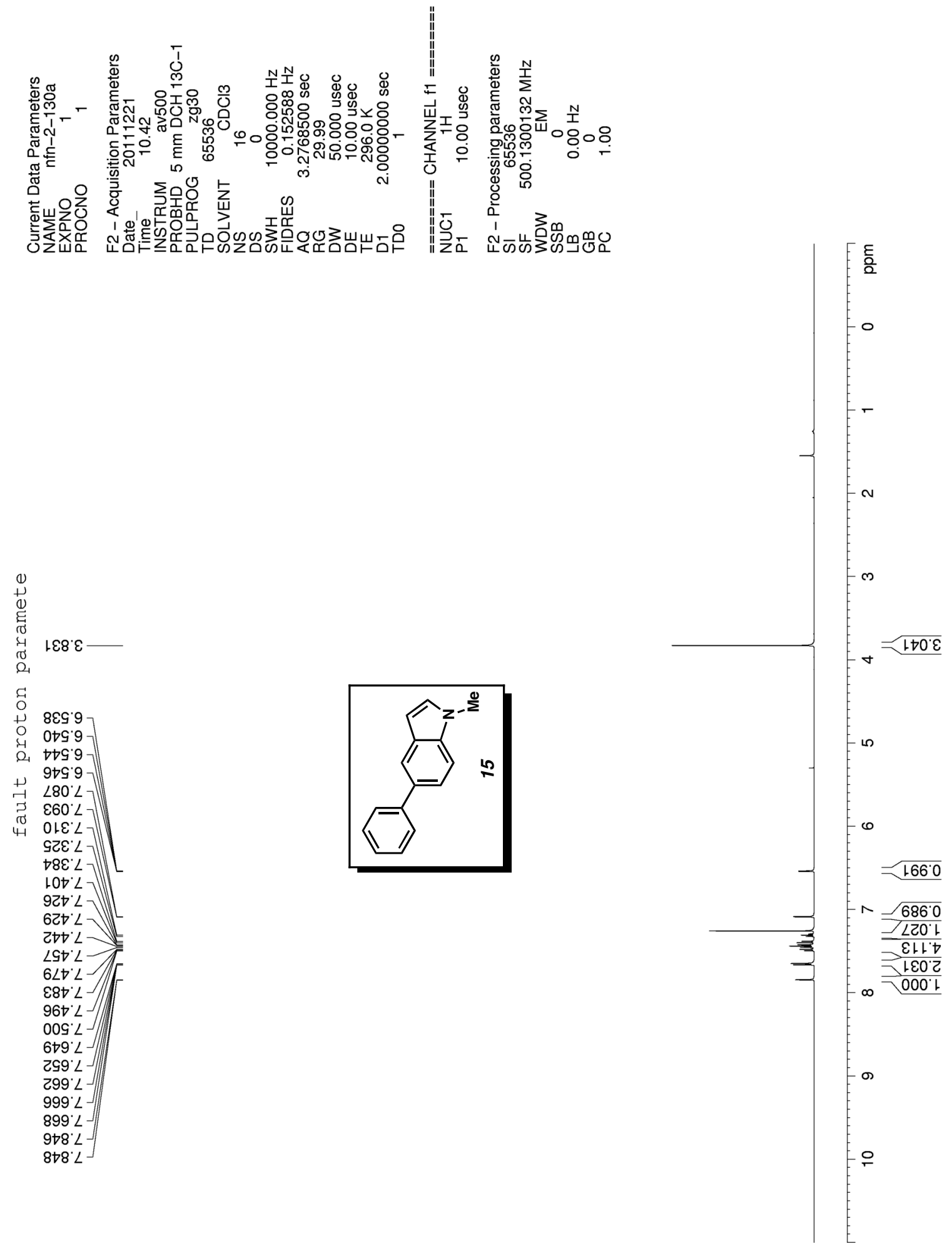

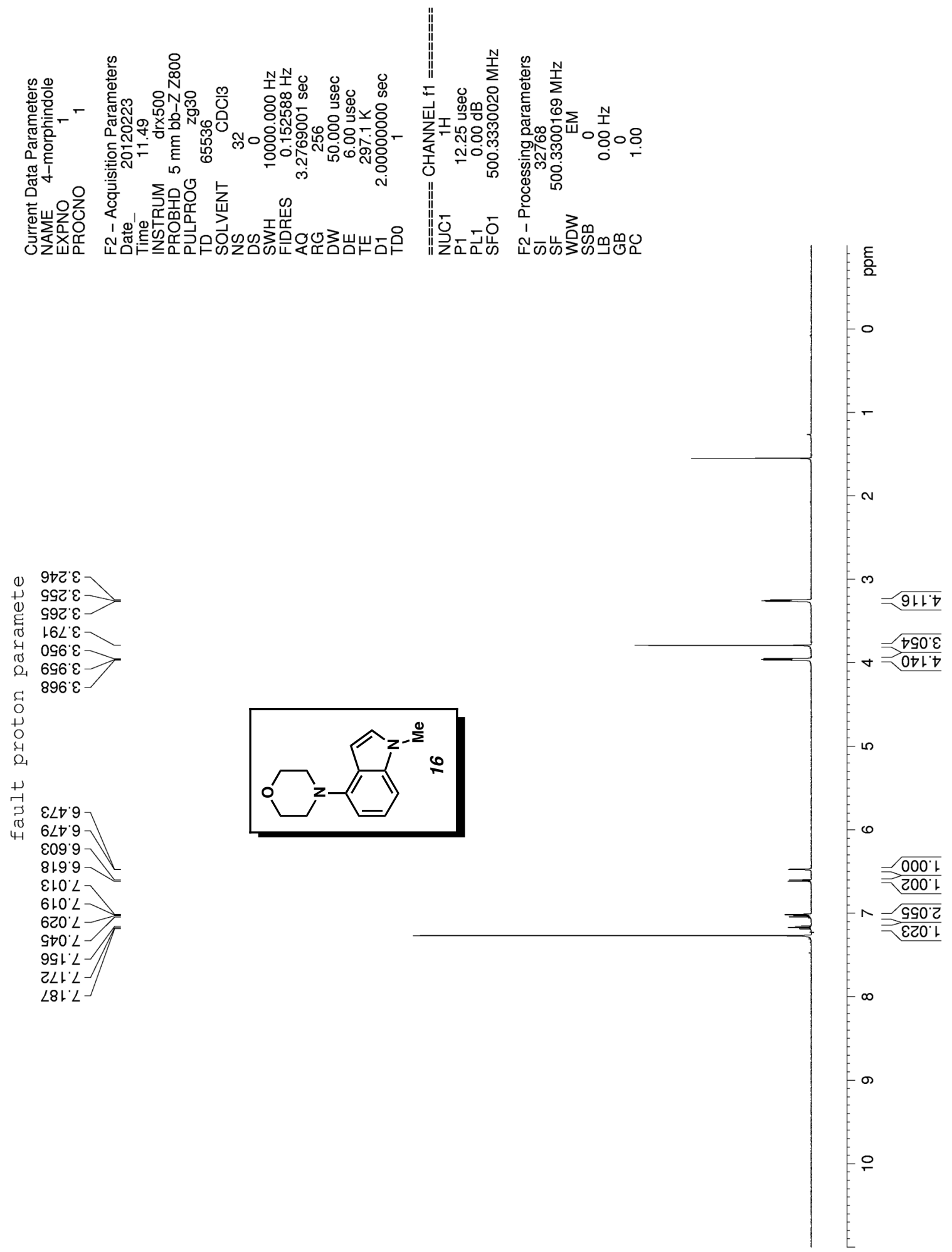

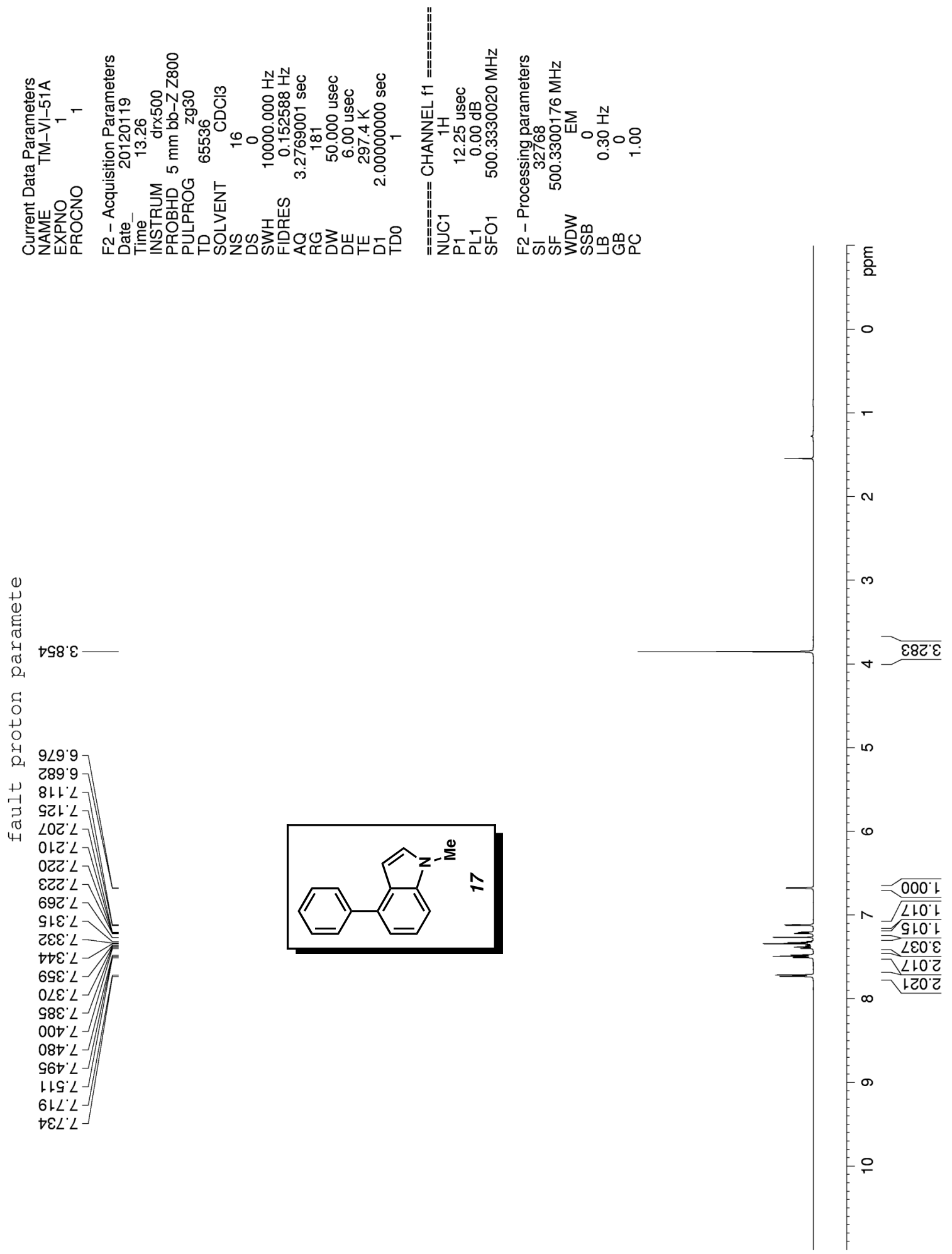
Mesganaw et al.: Cine Substitution of Arenes Supporting Information - S59

\section{${ }^{13}$ C NMR Spectra}



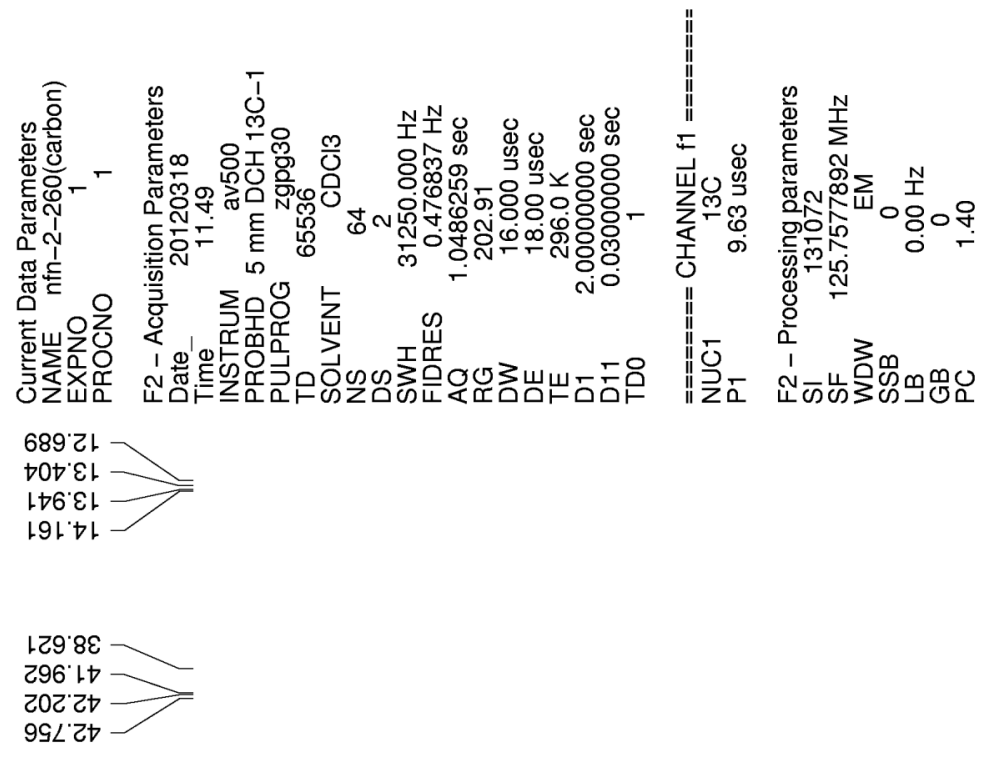

$\varepsilon \varepsilon\llcorner\varsigma$ ५

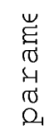

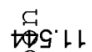

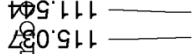

तु

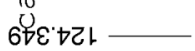

绨

928 0tト

$\angle t 66^{\circ} \varepsilon 91-$
L29.99L

$\neg 6 \varepsilon^{\circ} \angle 91$
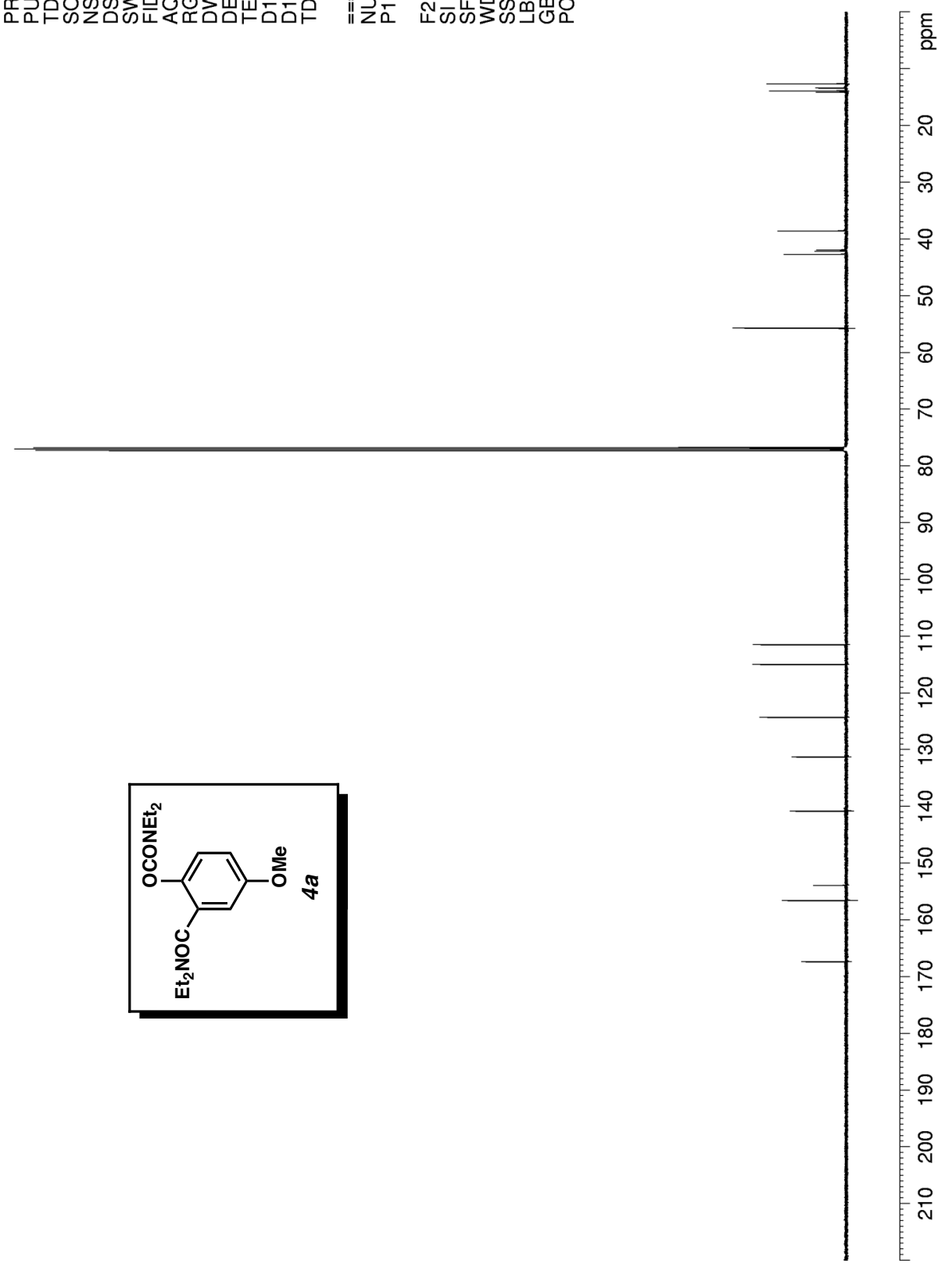


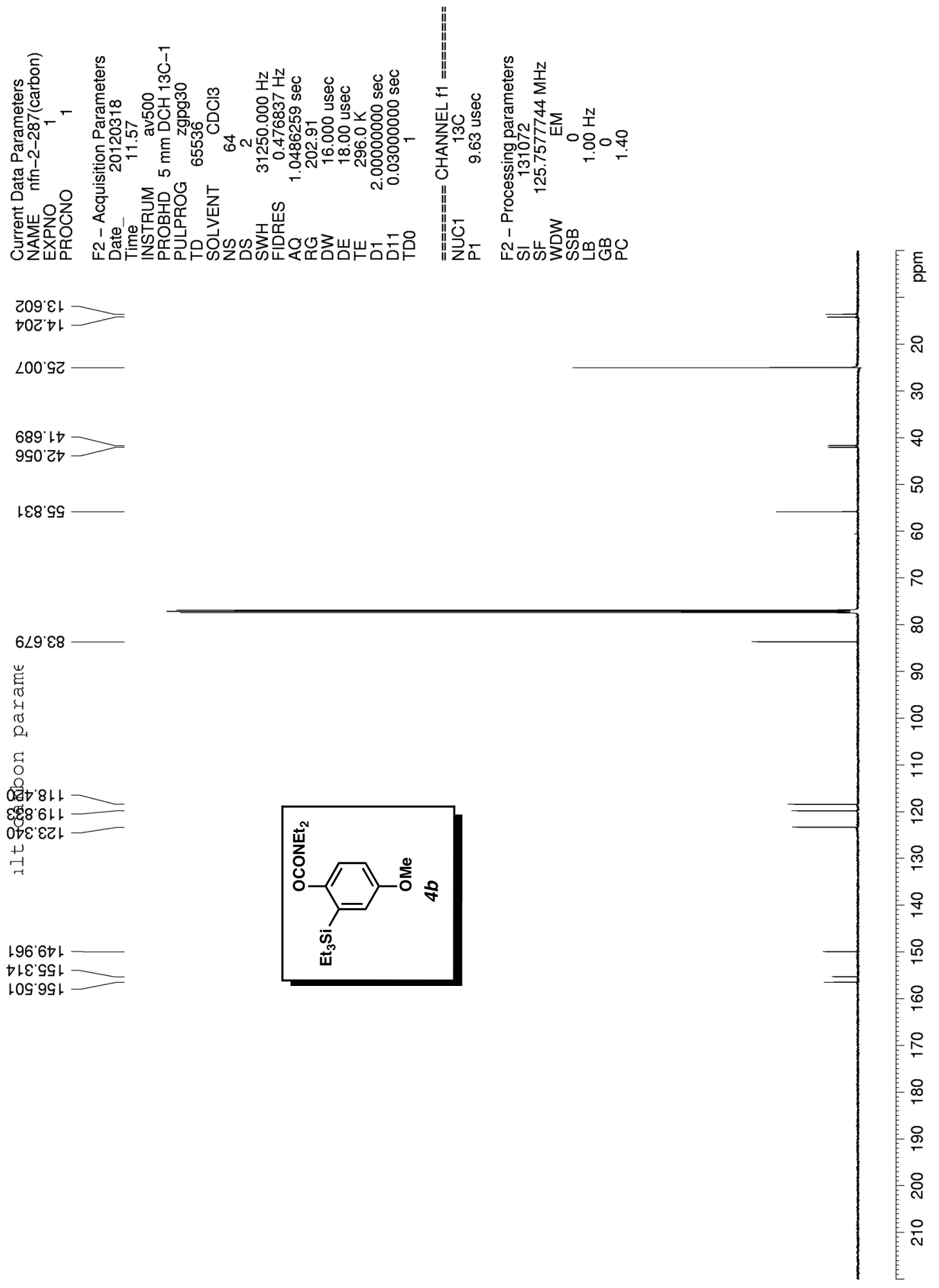



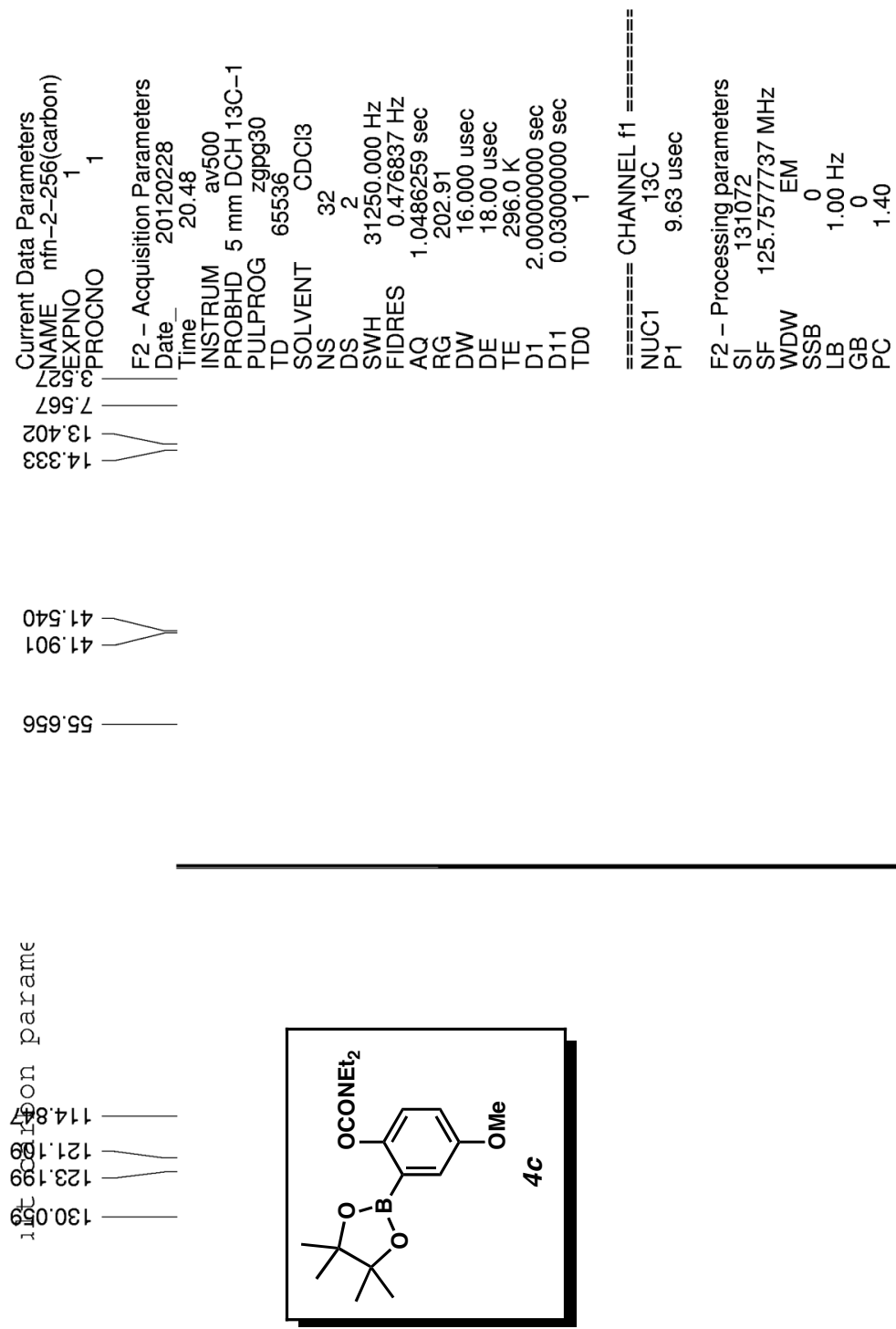

LOZ'0S L

$1 \angle 8^{\circ} \downarrow S+-$
เ8Z' $991-$

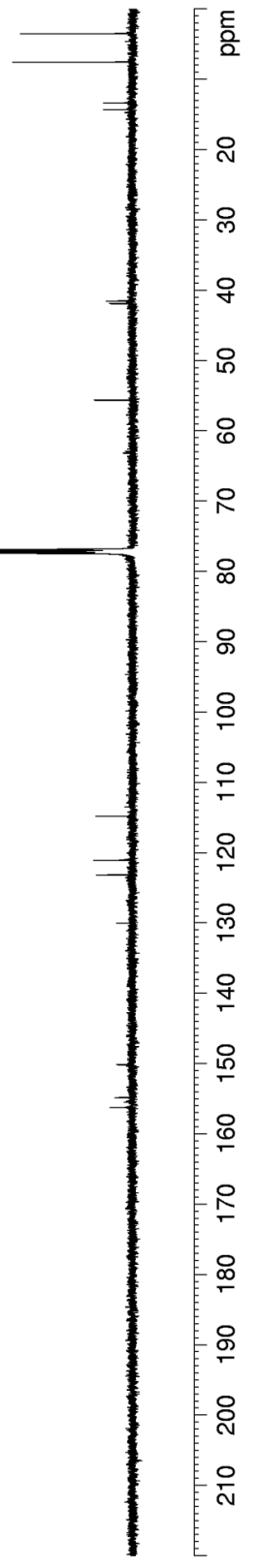




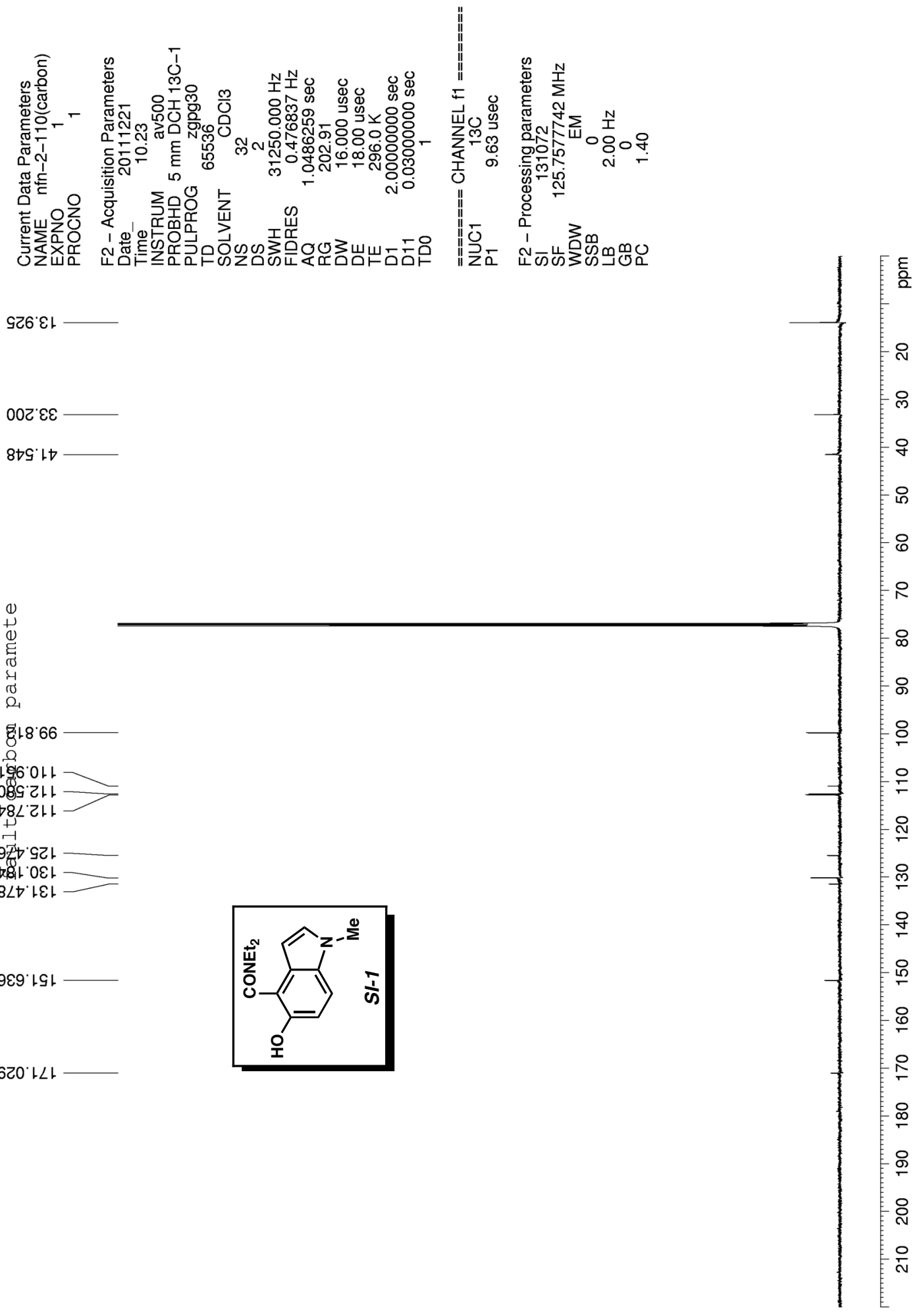



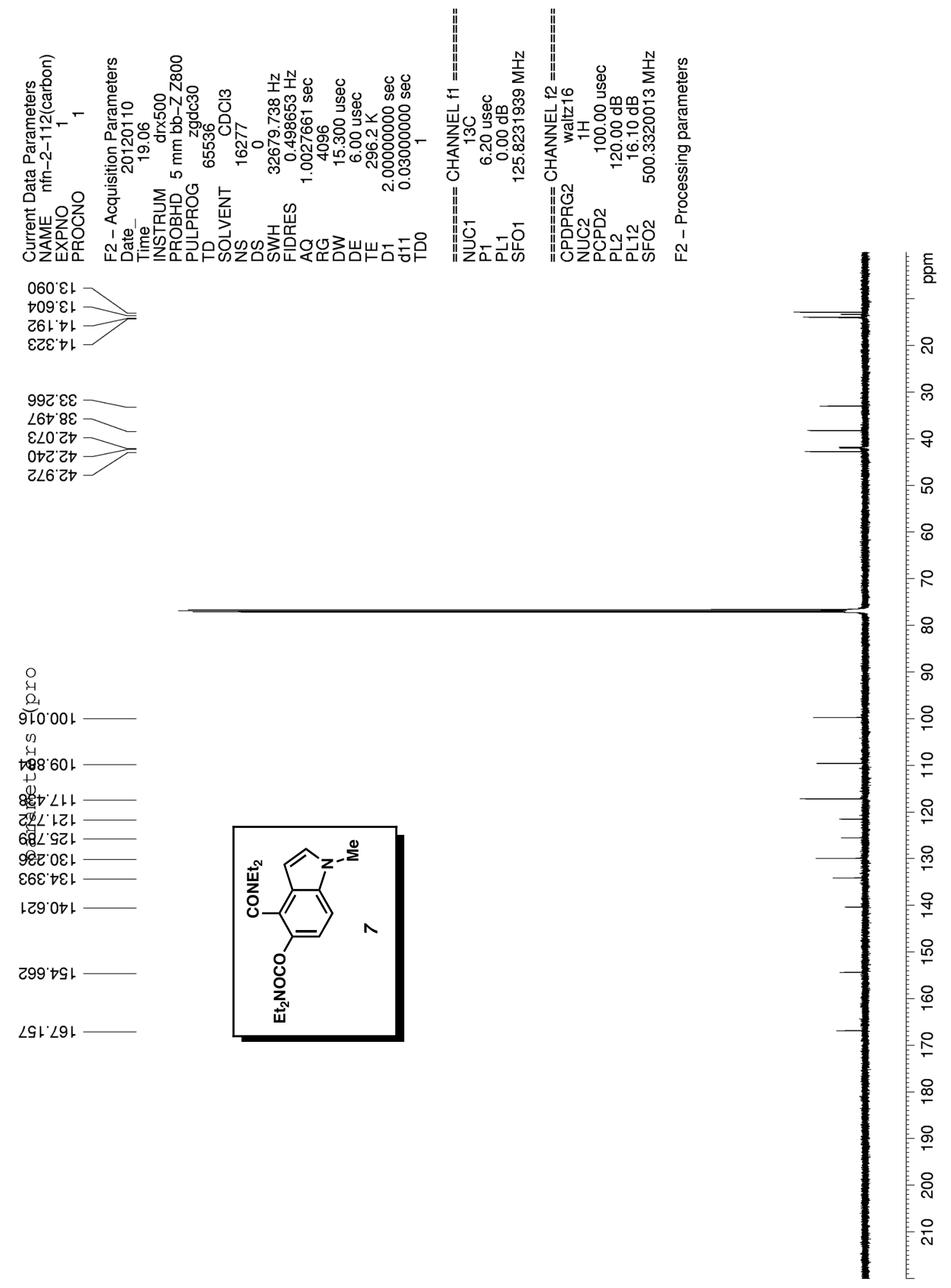


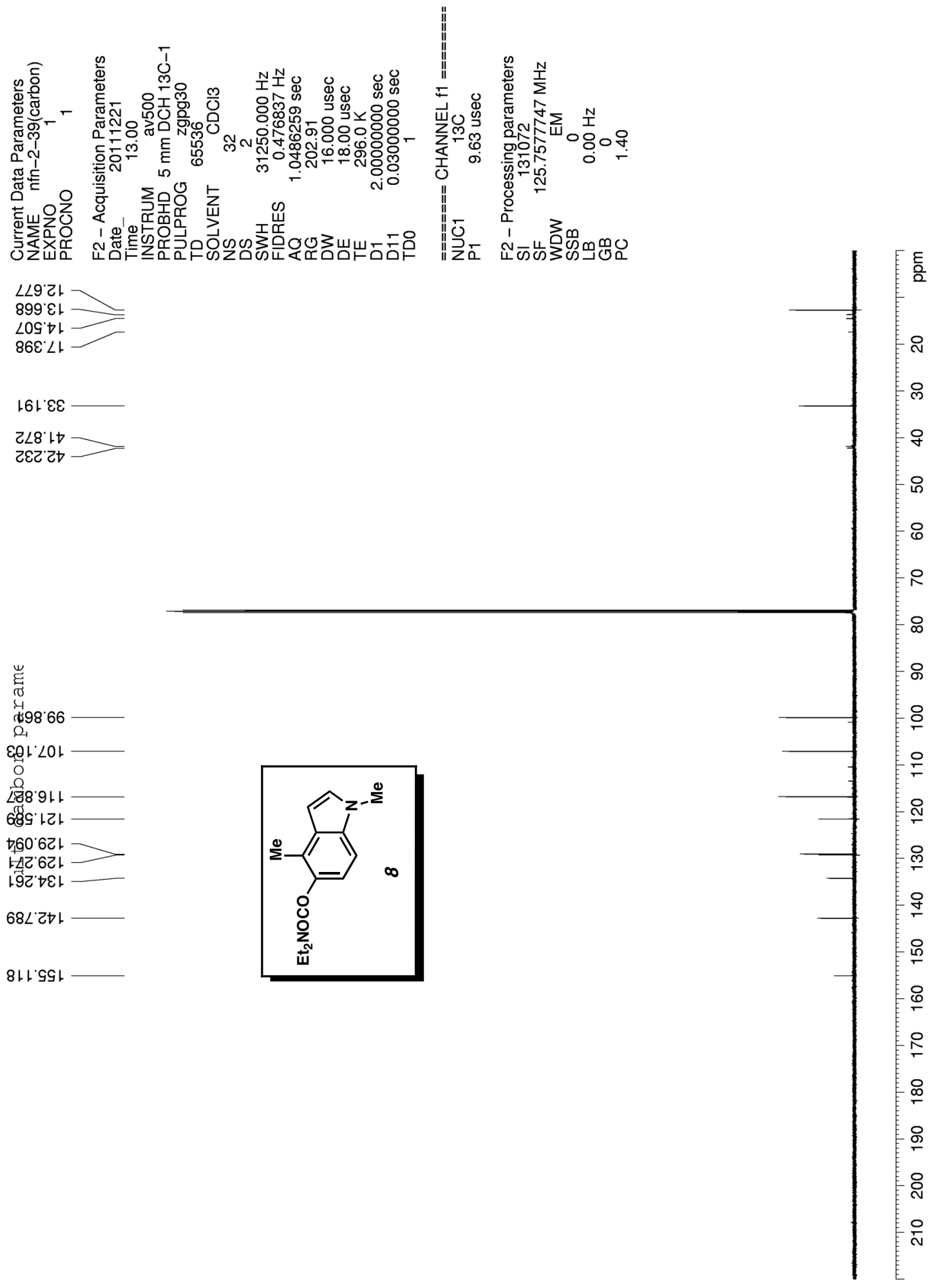




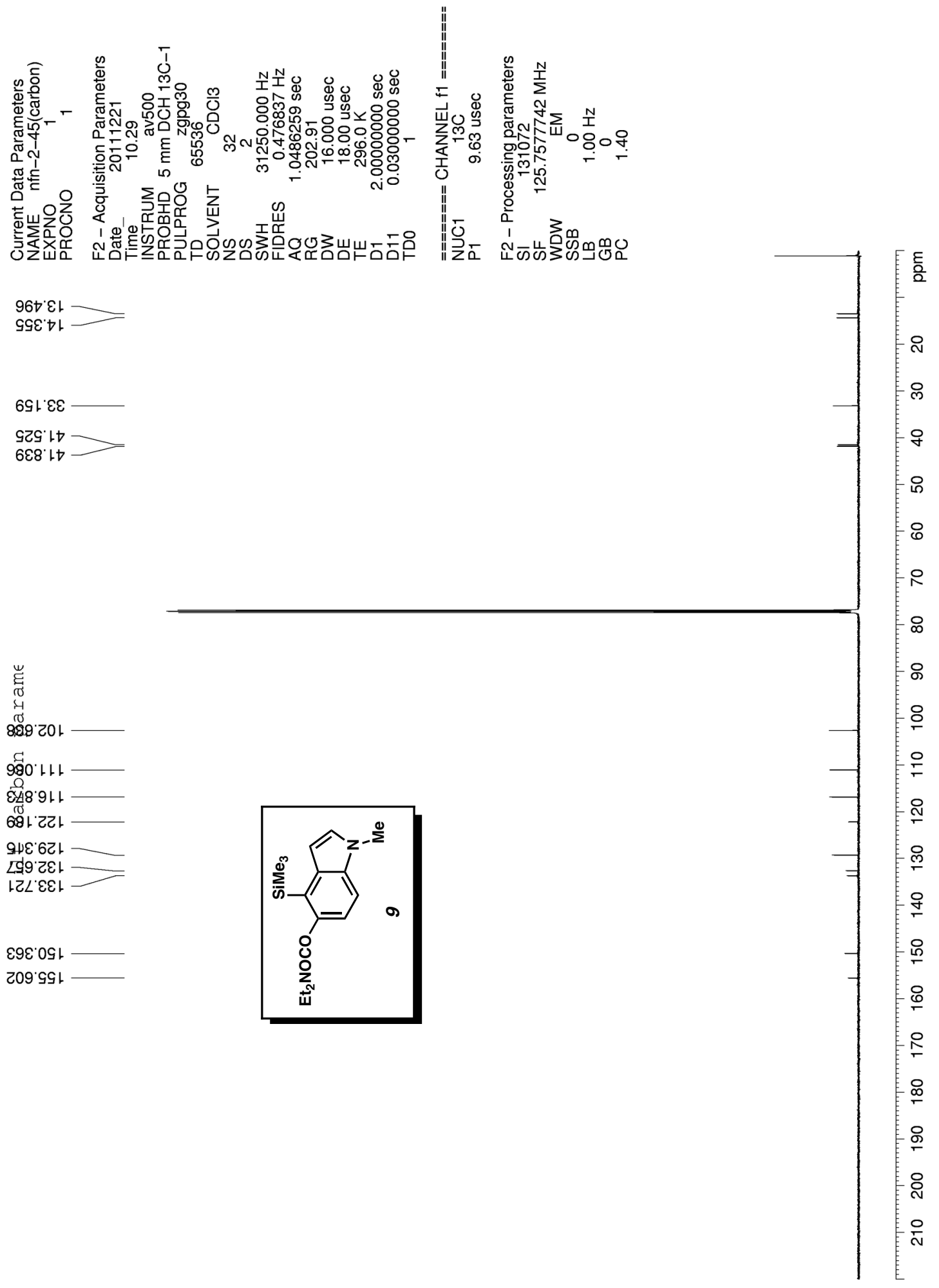




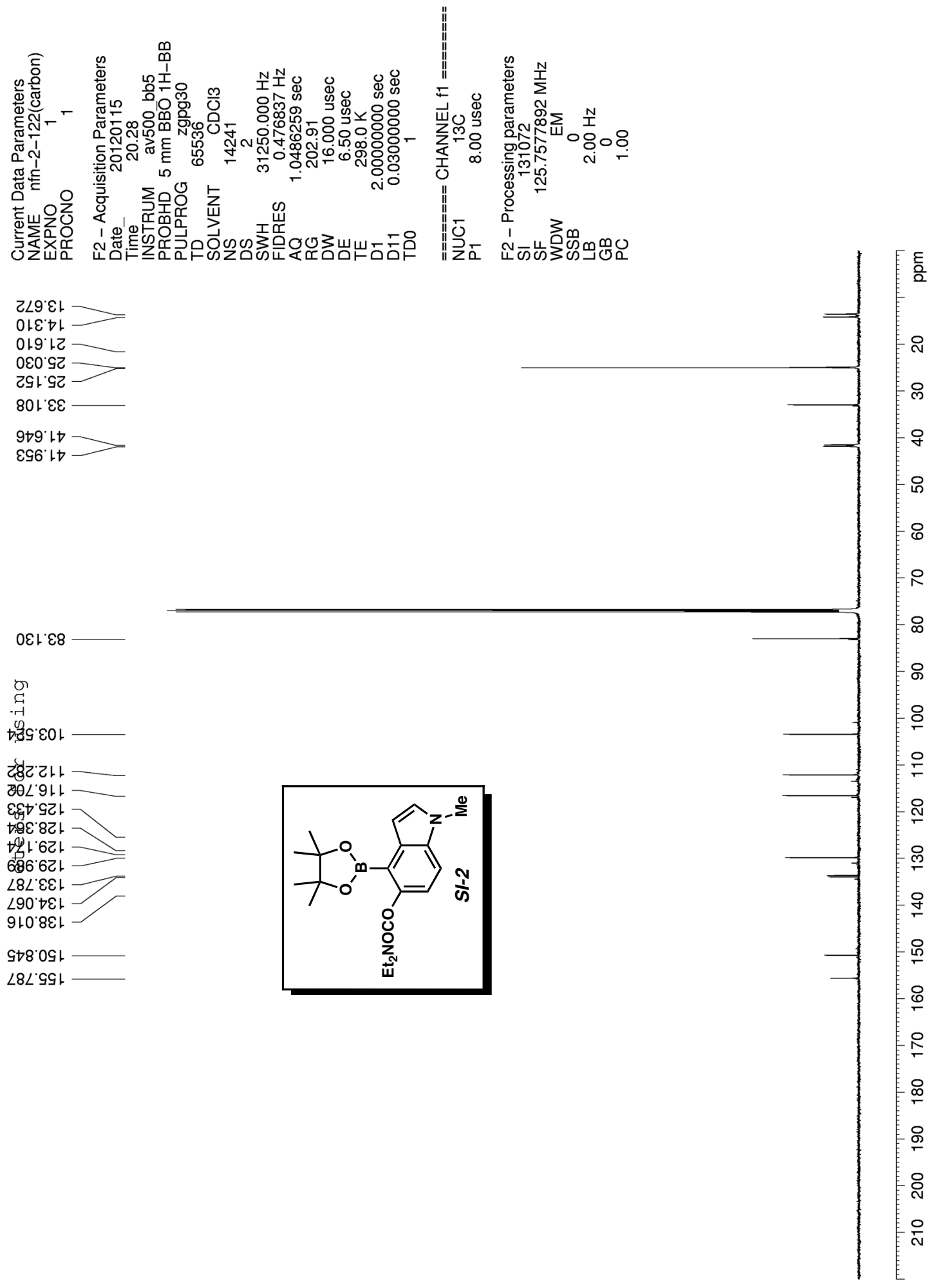




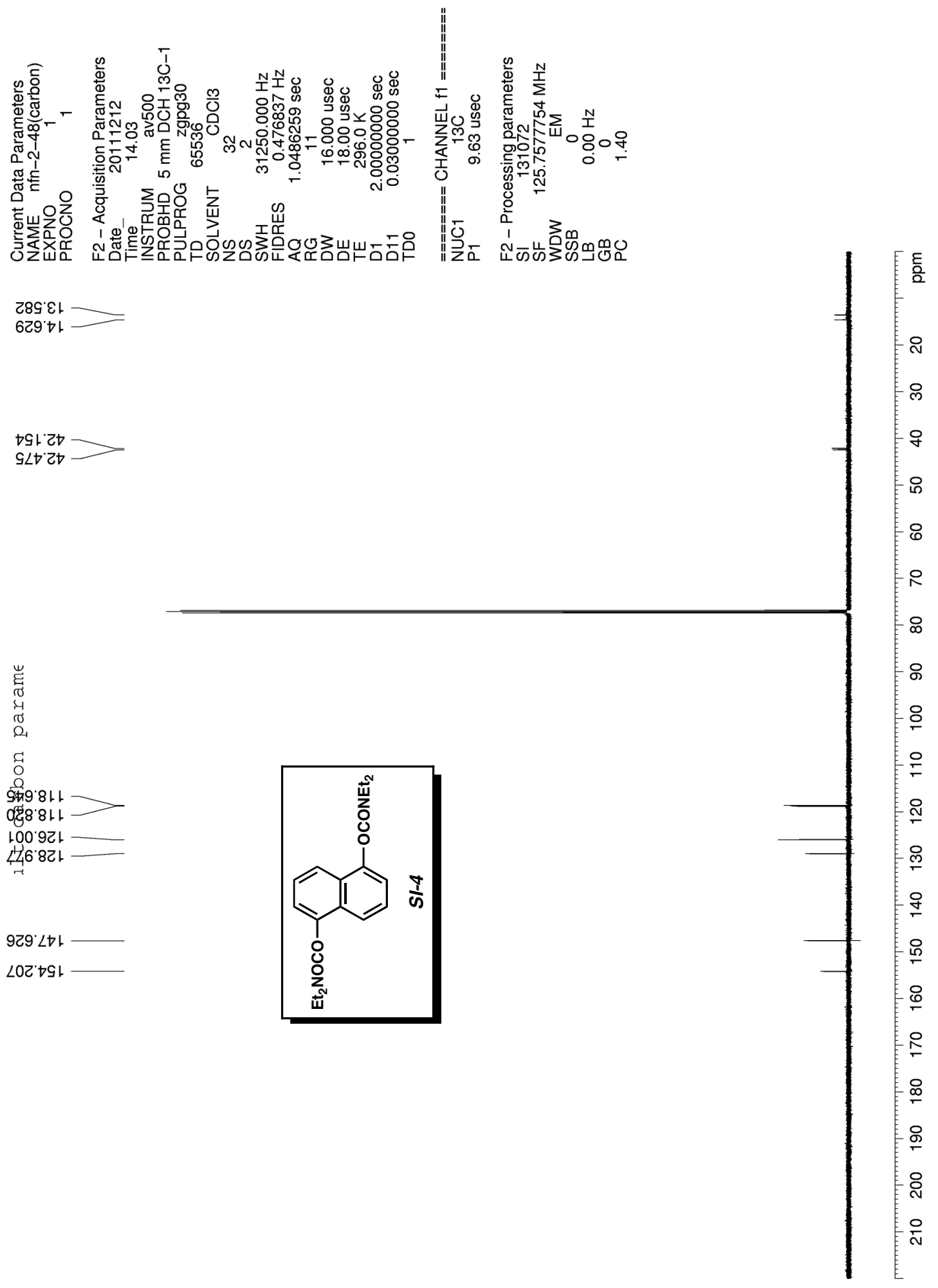




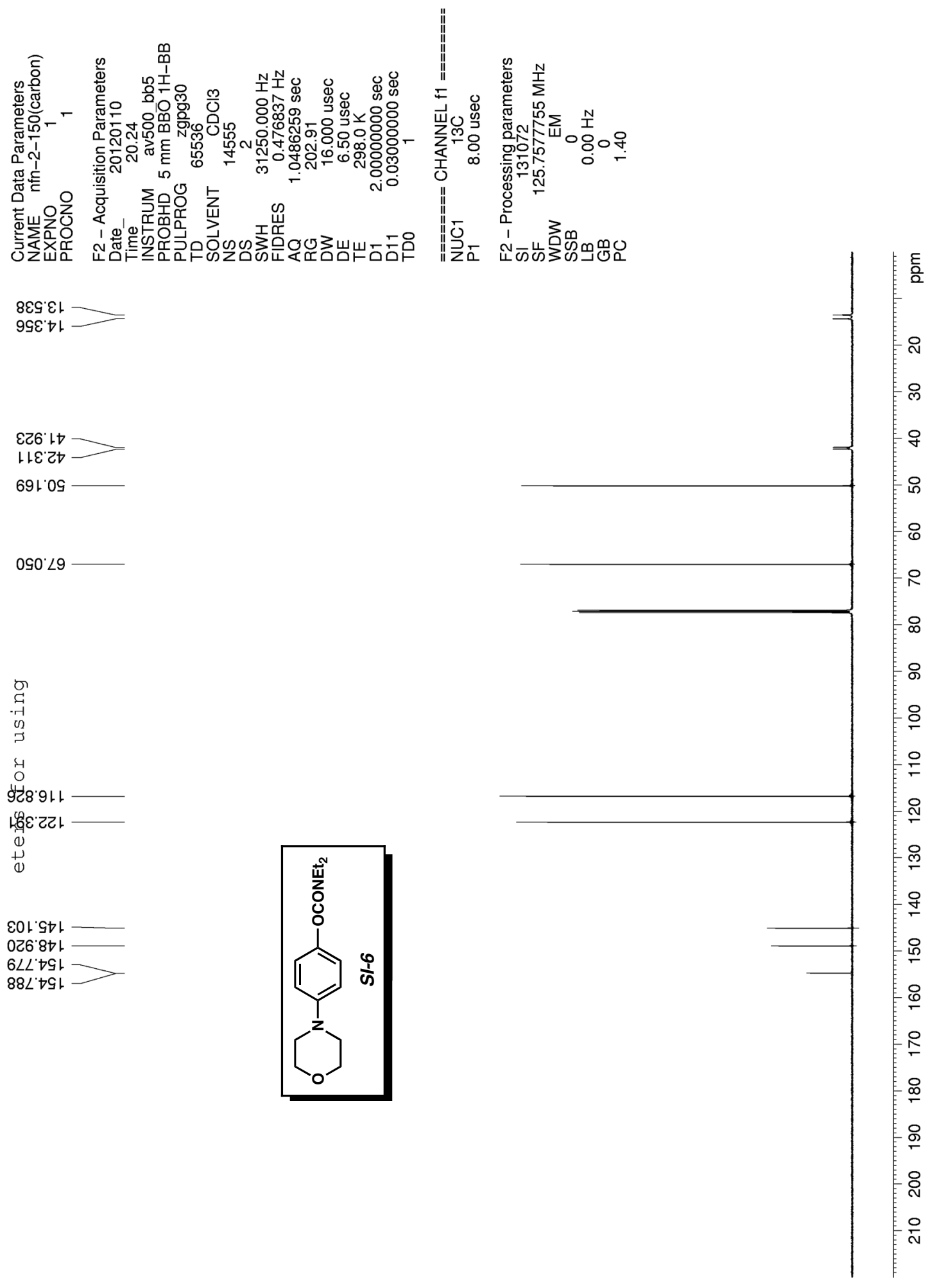




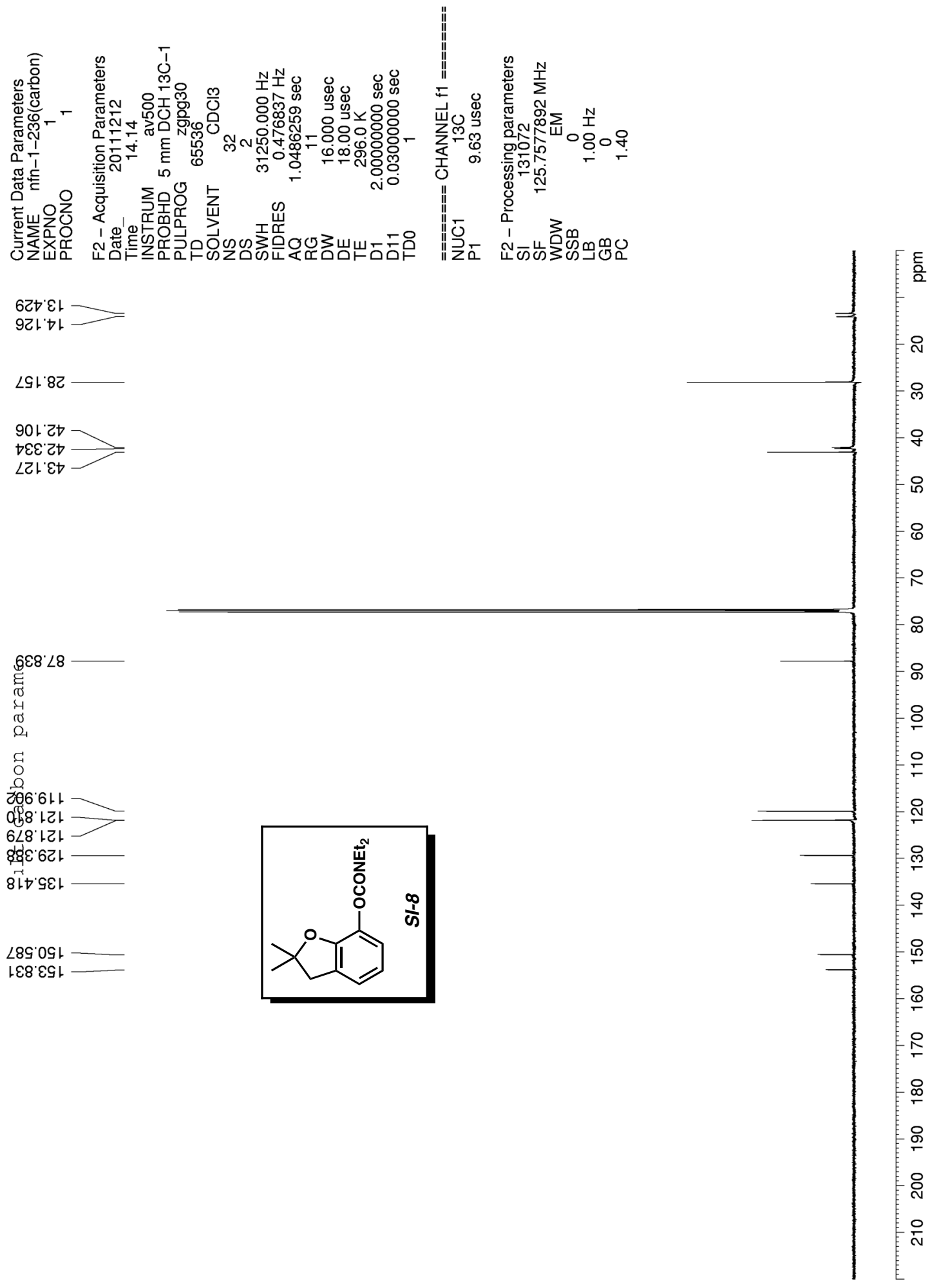




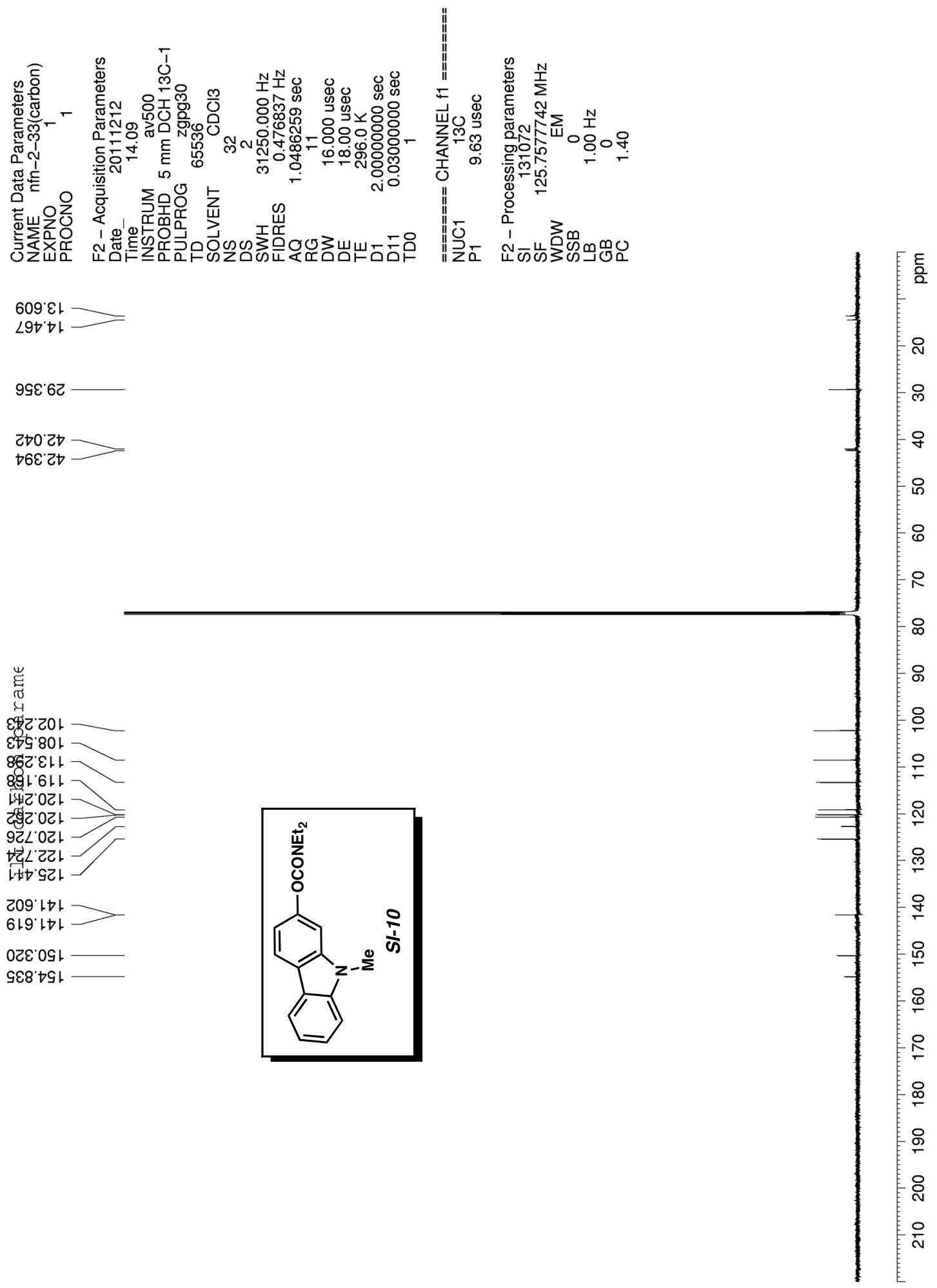




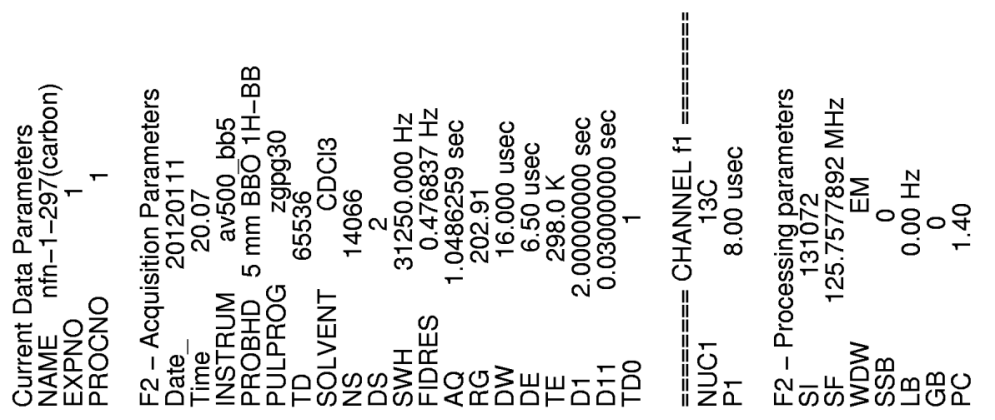

$9 \varepsilon \varepsilon \varepsilon+$

$\rightarrow 80^{\circ}+1-$

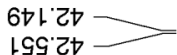

2
9
9
9
0
7

เөเ:Gน >

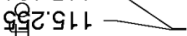

$\angle 9 L Z Z 1$

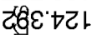

$590^{\circ} \angle Z 1$

$\triangle 69 \cdot 221$

698.821

$0 Z 96 \varepsilon$

$006.6 \varepsilon+$

टऽ6' $6 \varepsilon+$

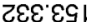

$\angle \angle 9 ' \varepsilon S$

6t9'sg

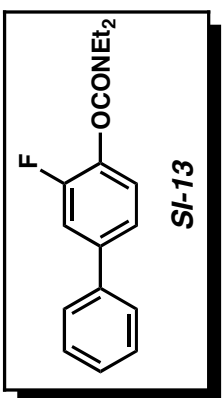




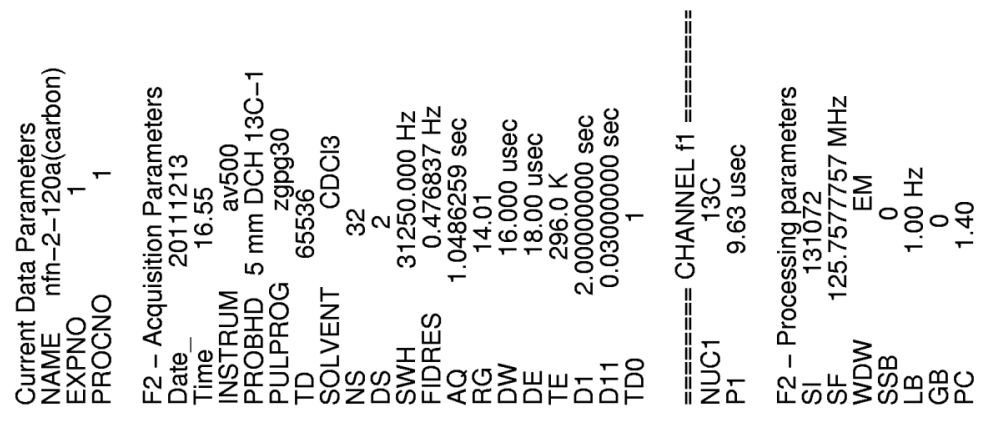

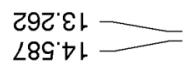

เレ'ยะ

G†6. $8 \varepsilon$

$69 \vdash^{\prime} \varepsilon t$

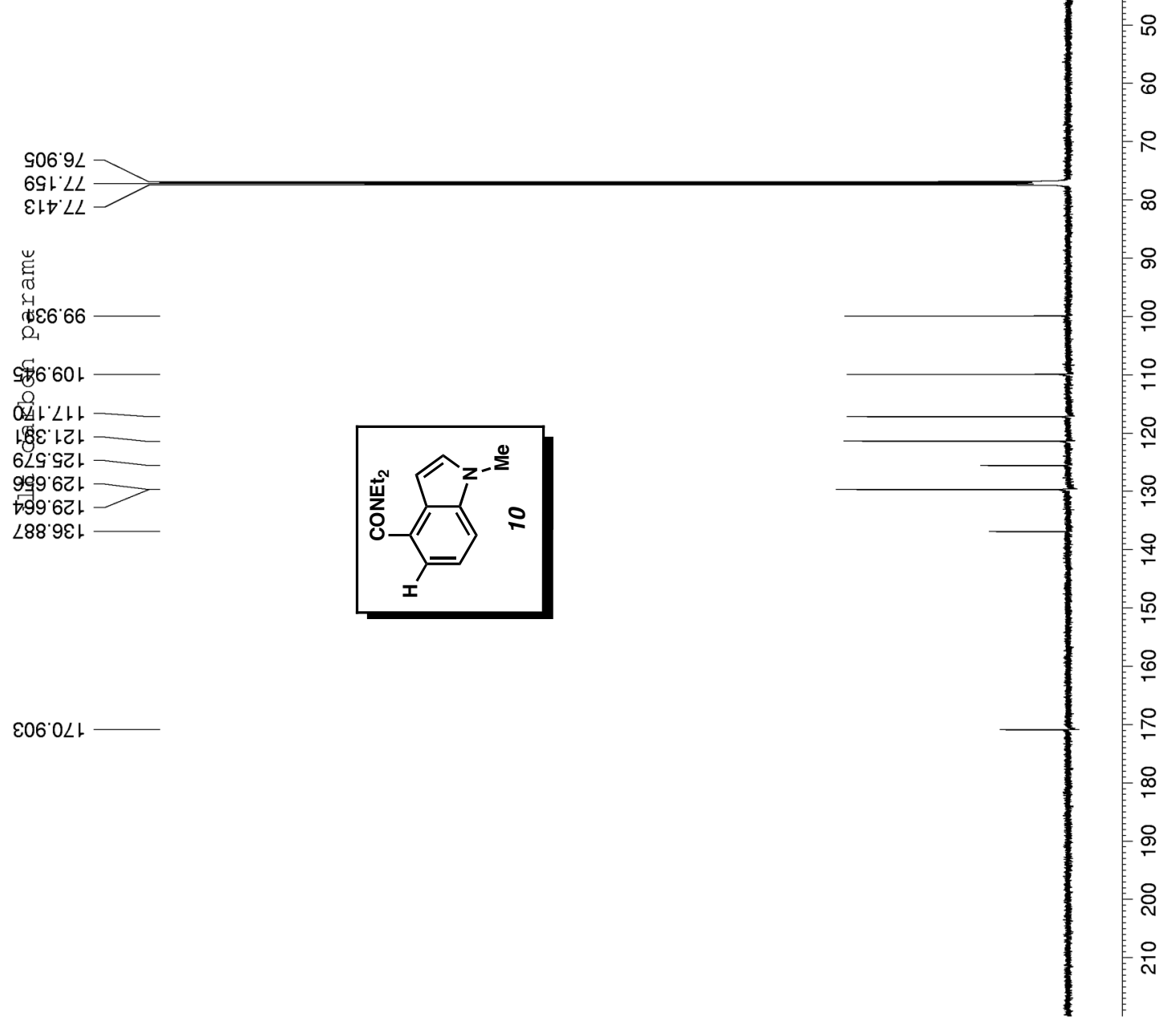



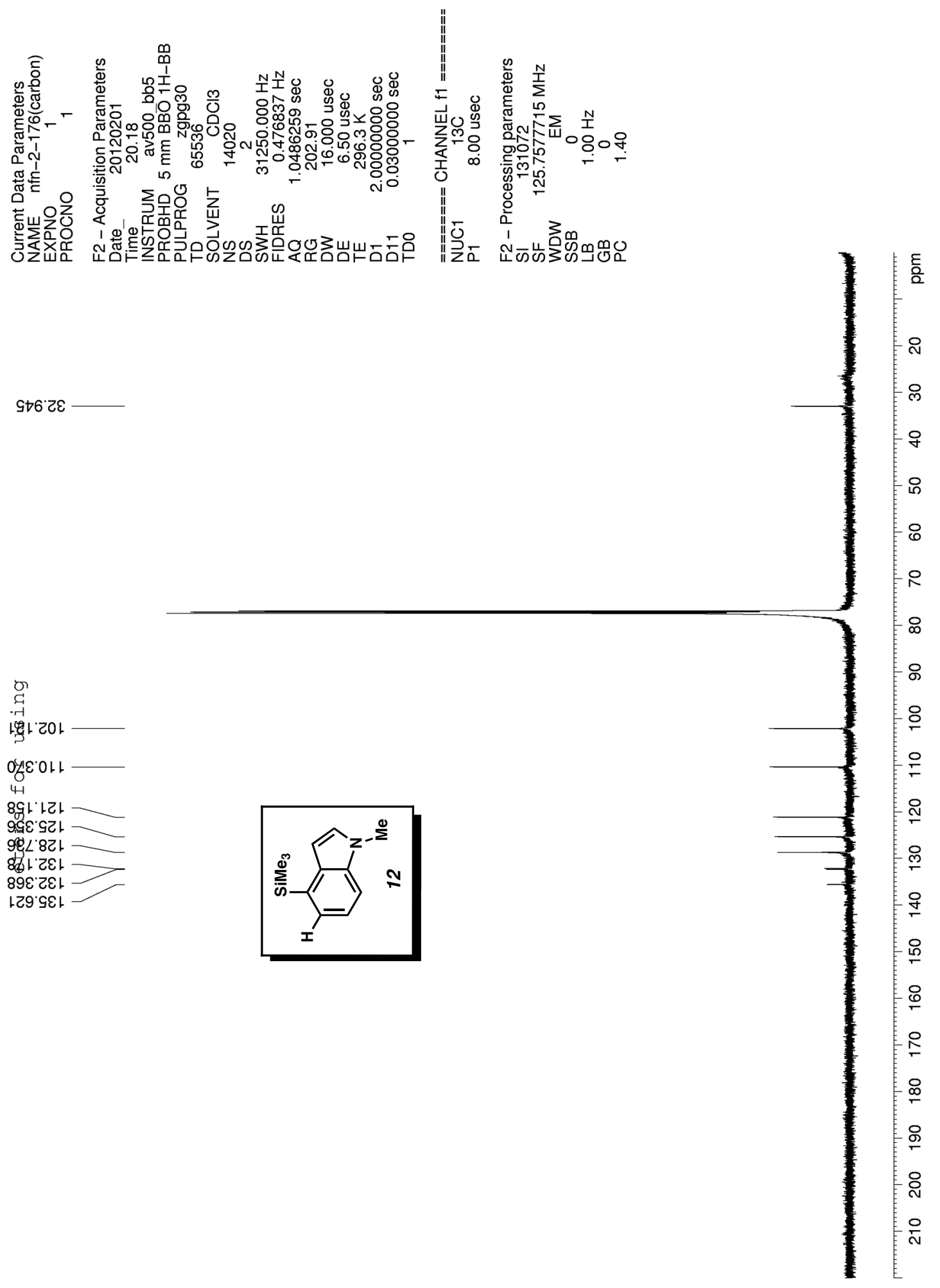

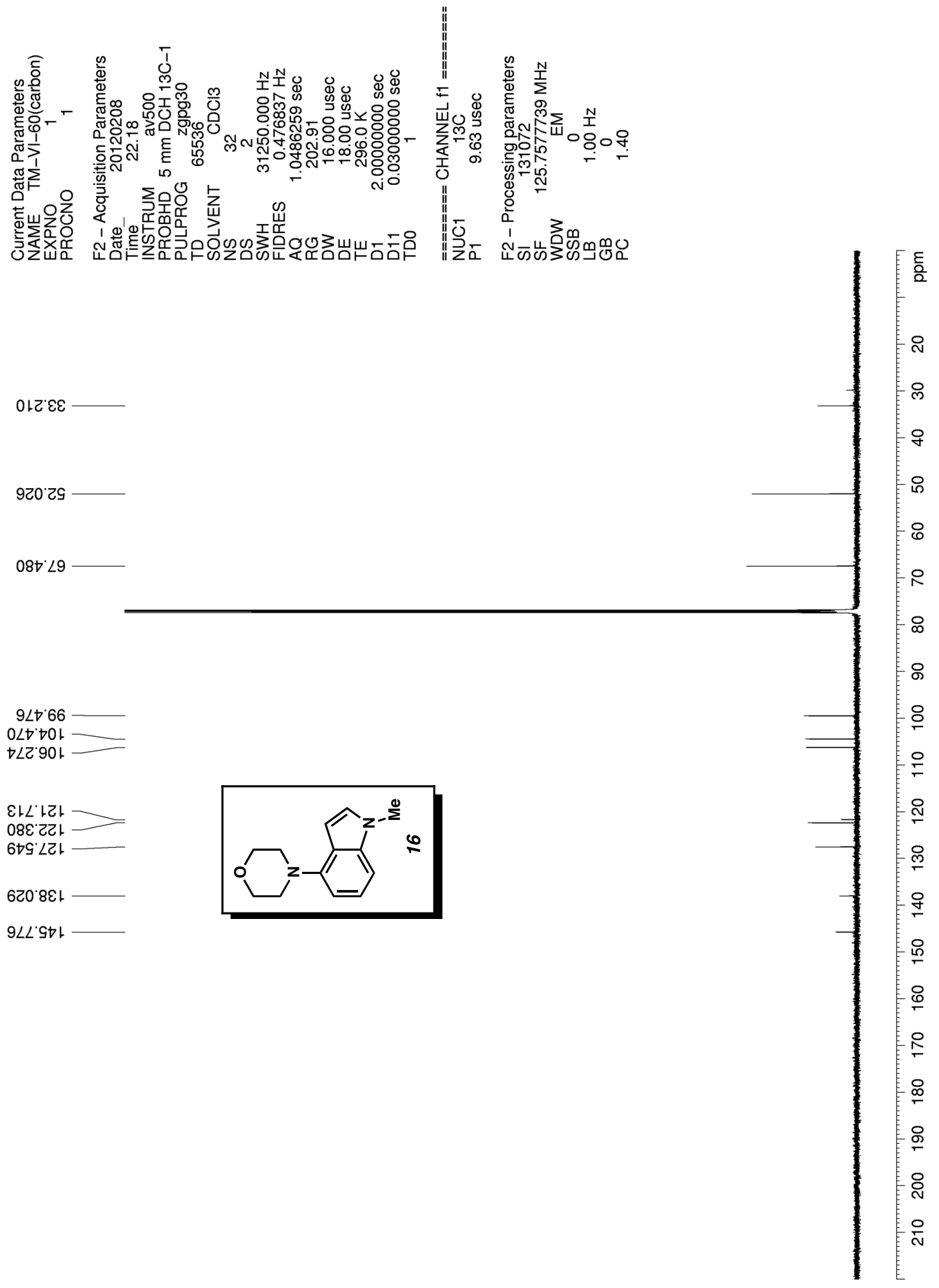

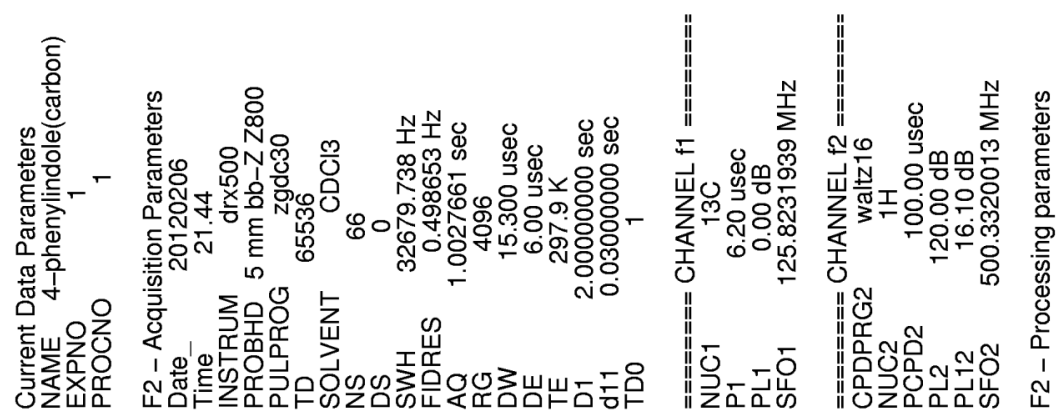

เ6L'Zع
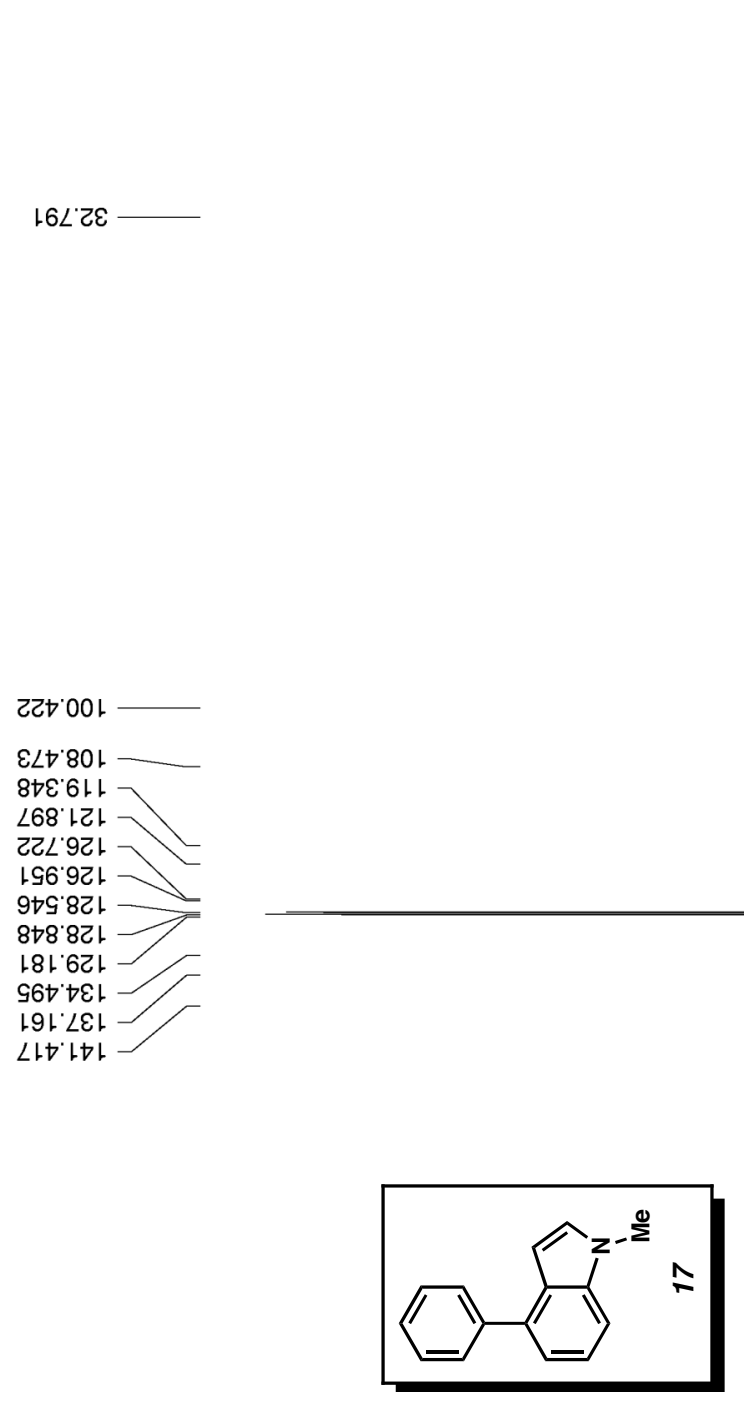

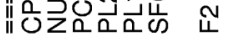
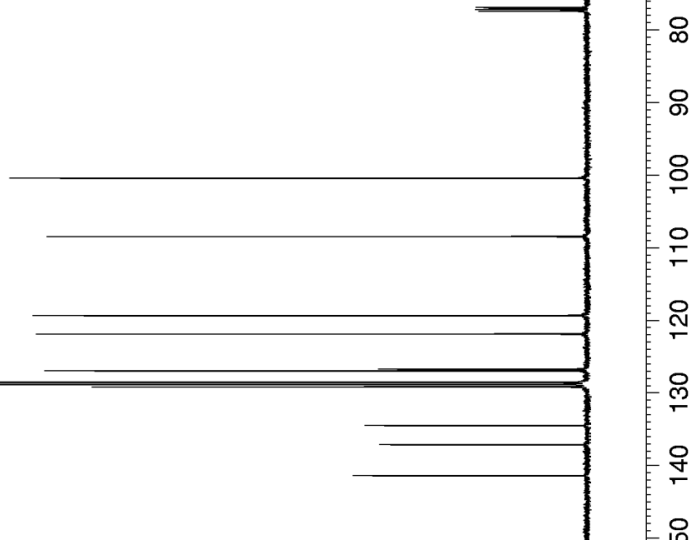